\begin{tabular}{|l|l|}
\hline 2. To: (Recsiving Organization) & $\begin{array}{l}\text { 3. From: (originating Organization) } \\
\text { ETTP/PE }\end{array}$ \\
ETTP/PE & 6. Cog. Engr.: \\
\hline 5. Proj./Pro!../Dept./Div.: & D. W. Hendrickson \\
EM-50/WT & $\begin{array}{l}\text { 8. Originator Renarks: } \\
\text { Cesium Removal Test Procedures/Instructions for Approval and } \\
\text { Release. }\end{array}$
\end{tabular}

11. Receiver Remarks:

4. Related EDT NO.:

611411

7. Purchase Order No.:

NA

9. Equip./Component No.:

NA

10. System/Bldg./Facility: 222-S \& 306E

12. Major Assm. Dwg. No.: NA

13. Permit/Permit Application No.: NA

14. Required Response Date: 30 May 1996

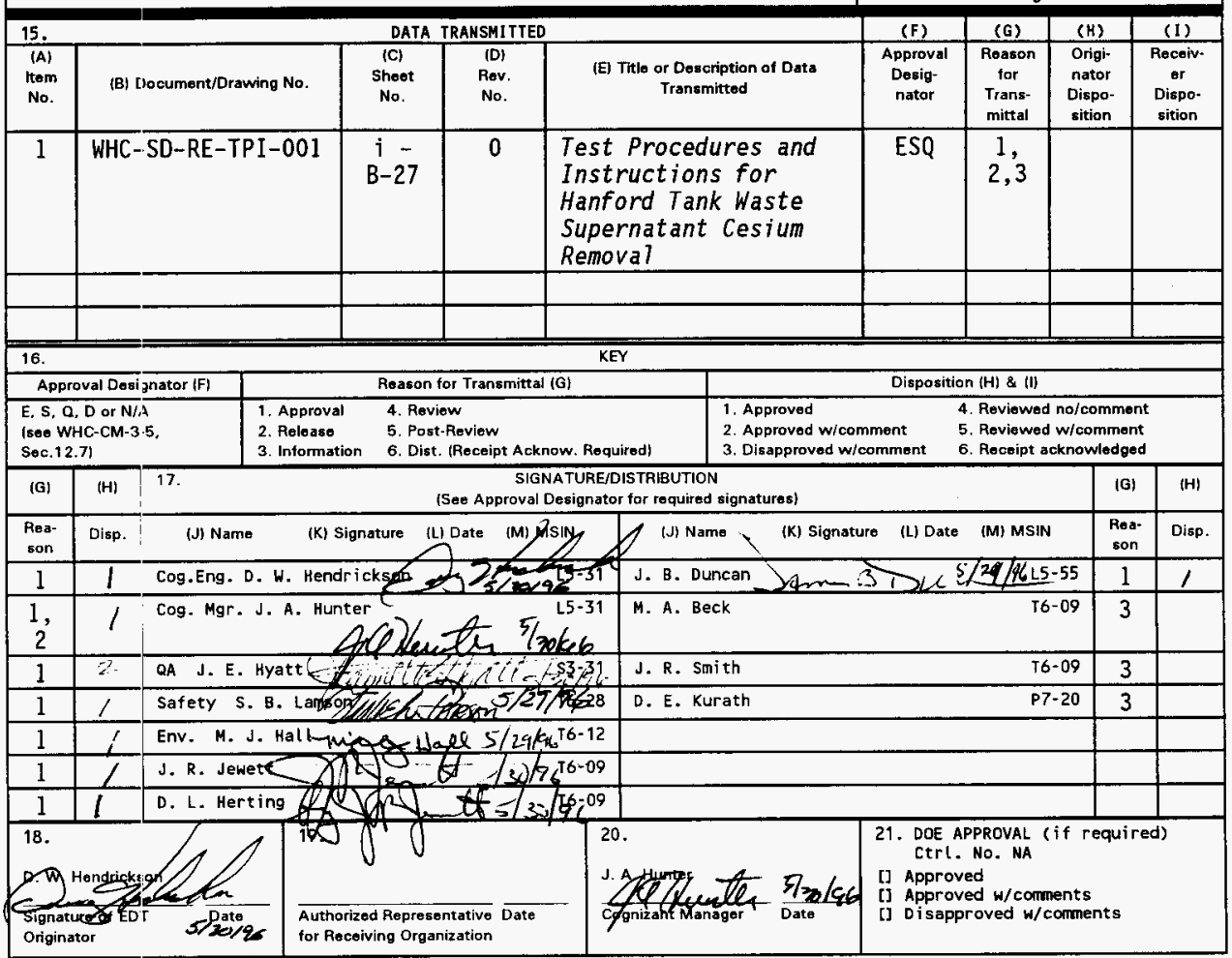

BD-7400-172-2(04/94) GEF097 


\title{
Test Procedures and Instructions for Hanford Tank Waste Supernatant Cesium Removal
}

\author{
D. W. Hendrickson
}

J. B. Duncan

Westinghouse Hanford Company, Richland, WA 99352

U.S. Department of Energy Contract DE-AC06-87RL10930

EDT/ECN: 611414

UC: 2020

Org Code: $8 \mathrm{~A} 400$

Charge Code: H2GA2

B\&R Code: EW4010000 Total Pages: 109

Key Words: Hanford, Tank Waste, DSSF, Cesium, Ion Exchange, Radioactive, Resorcinol-Formaldehyde, Crystalline Silicotitanate

Abstract: This document provides specific test procedures and instructions to implement the test plan for the preparation and conduct of a cesium removal test using Hanford Double-Shell Slurry Feed supernatant liquor from tank 241-AW-101 in a bench-scale column. Cesium sorbents to be tested include resorcinol-formaldehyde resin and crystalline silicotitanate. The test plan for which this provides instructions is WHC-SD-RE-TP-022, Hanford Tank Waste Supernatant Cesium Removal Test Plan.

TRADEMARK DISCLAIMER. Reference herein to any specific commercial product, process, or service by trade name, tradenark, manufacturer, or otherwise, does not necessarily constitute or imply its endorsement, recomendation, or favoring by the United States Government or any agency thereof or its contractors or subcontractors.

Printed in the United States of America. To obtain copies of this document, contact: WHC/BCS Docunent Control Services, P.O. Box 1970, Mailstop H6-08, Richland WA 99352, Phone (509) 372-2420, Fax (509) 376-4989.
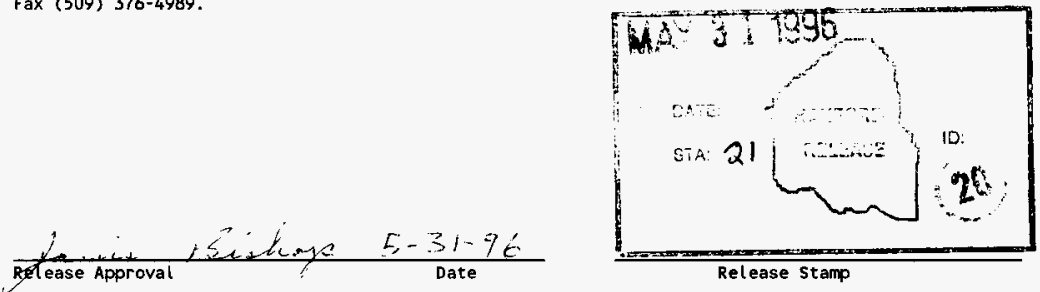
WHC-SD-RE-TPI-001, Rev. 0

THIS PAGE INTENTIONALLY LEFT BLANK 
1.0 INTRODUCTION $\ldots \ldots \ldots \ldots \ldots \ldots \ldots \ldots \ldots \ldots \ldots$

2.0 DESCRIPTION OF TEST $\ldots \ldots \ldots \ldots \ldots \ldots \ldots \ldots \ldots \ldots$

2.1 TEST ENVIRONMENT $\ldots \ldots \ldots \ldots \ldots \ldots \ldots \ldots \ldots$

2.2 EQUIPMENT AND FACILITIES $\ldots \ldots \ldots \ldots \ldots \ldots \ldots \ldots \ldots . \ldots$

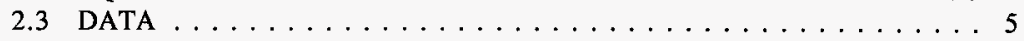

2.4 CRITERIA/CONSTRAINTS $\ldots \ldots \ldots \ldots \ldots \ldots \ldots$

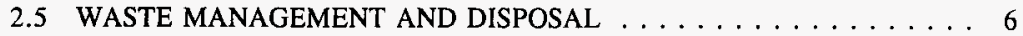

3.0 EXPECTED RESULTS $\ldots \ldots \ldots \ldots \ldots \ldots \ldots \ldots \ldots$

4.0 TEST PROCEDURE $\ldots \ldots \ldots \ldots \ldots \ldots \ldots \ldots \ldots \ldots$

4.1 SYSTEM ACCEPTANCE TESTING AND CALIBRATIONS . . . . . . 7

4.1 .1 Equipment Assembly $\ldots \ldots \ldots \ldots \ldots \ldots \ldots \ldots \ldots$

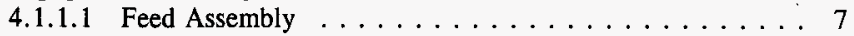

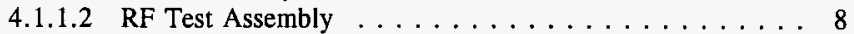

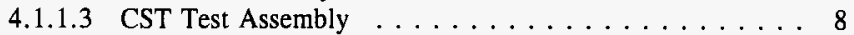

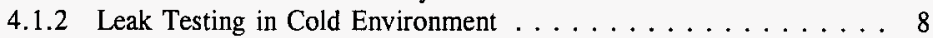

4.1.2.1 RF Subassembly Leak Testing . . . . . . . . . . 8

4.1.2.2 CST Subassembly Leak Test . . . . . . . . . . . . . 14

4.1 .3 Reagent Preparation . . . . . . . . . . . . . . . . 17

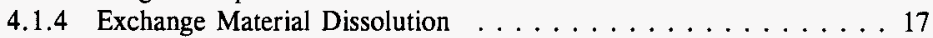

4.1.4.1 R-F Resin . . . . . . . . . . . . . . . . 17

4.1.4.2 CST Resin . . . . . . . . . . . . . . 18

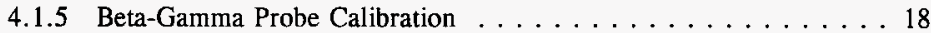

4.2 R-F TEST PREPARATION AND RUN $\ldots \ldots \ldots \ldots \ldots \ldots \ldots$

4.2 .1 Pump Flow Set $\ldots \ldots \ldots \ldots \ldots \ldots \ldots \ldots \ldots$

4.2.2 Exchange Column Preparation . . . . . . . . . . . . . . 19

4.2.3 R-F Apparatus Pump Curve Acquisition . . . . . . . . . . . . . 19

4.2.4 R-F Waste Feed Preparation and Analysis . . . . . . . . 20

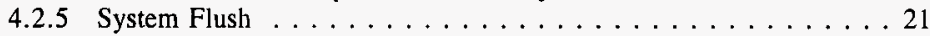

4.2.6 Cesium Removal Test Run . . . . . . . . . . . . . . . . 22

4.2.6.1 Beta-Gamma Detector Data Logging . . . . . . . . 22

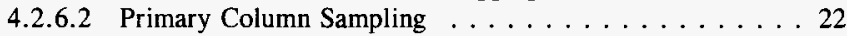

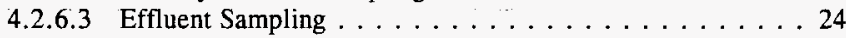

4.2.6.4 Run Execution . . . . . . . . . . . . . . . . . . . . 24

4.2 .7 System Flush . . . . . . . . . . . . . . . . . . 24

4.2 .8 Column Elution . . . . . . . . . . . . . . . . . . 25

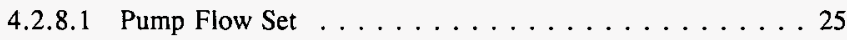


TABLE OF CONTENTS - continued

4.2.8.2 Primary Column Elution $\ldots \ldots \ldots \ldots \ldots \ldots . \ldots 25$

4.2.8.3 Secondary Column Elution $\ldots \ldots \ldots \ldots \ldots \ldots$

4.3 CST TEST PREPARATION AND RUN $\ldots \ldots \ldots \ldots \ldots \ldots \ldots \ldots$

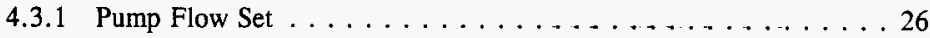

4.3.2 Exchange Column Preparation . . . . . . . . . . . . . 27

4.3.3 CST Apparatus Pump Curve Acquisition . . . . . . . . . 27

4.3.4 CST Waste Feed Preparation and Analysis . . . . . . . . 28

4.3 .5 System Flush . . . . . . . . . . . . . . . . . . . 29

4.3.6 Cesium Removal Test Run . . . . . . . . . . . . . . . . 29

4.3.6.1 Beta-Gamma Detector Data Logging . . . . . . . . . . 30

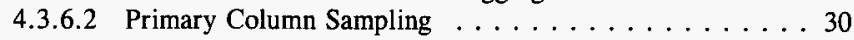

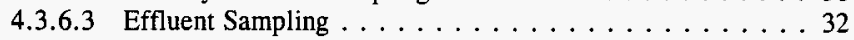

4.3.6.4 Run Execution . . . . . . . . . . . . . . . 32

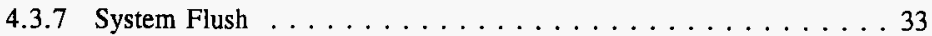

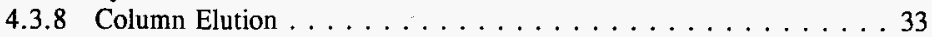

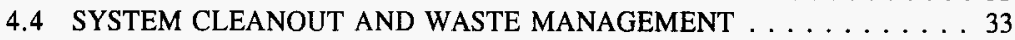

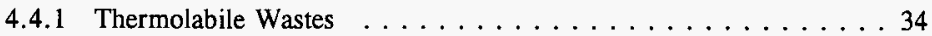

4.4 .2 Resin Columns . . . . . . . . . . . . . . 34

4.4 .3 Other Liquors . . . . . . . . . . . . . . . . . . 34

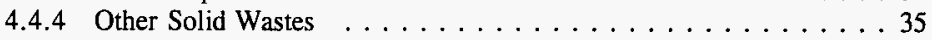

4.5 SAMPLING AND SAMPLE ANALYSES $\ldots \ldots \ldots \ldots \ldots$

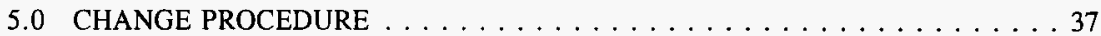

5.1 General Changes . . . . . . . . . . . . . . . . . . 37

5.2 Sampling Frequency Change $\ldots \ldots \ldots \ldots \ldots \ldots \ldots \ldots \ldots \ldots$

5.3 Pump Flow Rate Reset $\ldots \ldots \ldots \ldots \ldots \ldots$

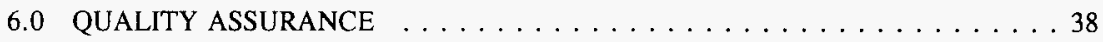

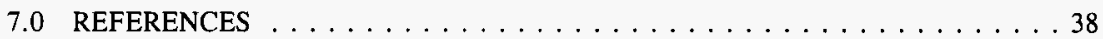

A: Checksheets and Data Sheets $\ldots \ldots \ldots \ldots \ldots \ldots \ldots \ldots \ldots \ldots$ A-i

B: Material Safety Data Sheets $\ldots \ldots \ldots \ldots \ldots \ldots \ldots \ldots \ldots \ldots \ldots$ 


\section{LIST OF FIGURES}

Figure 1: Bench-Scale Cesium Exchange Flows and Instrumentation . . . . . . . . 2

Figure 2: Physical Test Assembly Valve and Column Arrangement $\ldots \ldots \ldots \ldots$.

Figure A-3: Bench-Scale Cesium Exchange Flows and Instrumentation . . . . . . . A A-1

Figure A-4: Physical Test Assembly Valve and Column Arrangement . . . . . . . . A-1

\section{LIST OF TABLES}

PAGE

Table: 1: Reagent Densities at Experimental Temperature . . . . . . . . . . 5

Table: 2: Valve Connection/Function for R-F Resin Columns . . . . . . . . . . . . . 9

Table 3: Valve Connection/Function for CST Resin Columns . . . . . . . . . . 11

Table: 4: R-F Test Run Primary Column Sampling . . . . . . . . . . . . . 23

Table 5: CST Test Run Primary Column Sampling . . . . . . . . . . . . . 31

Table 6: Cesium Ion Exchange Summary Sample Analysis Plan . . . . . . . . . . 35

\section{LIST OF APPARATUS FLOW CONFIGURATIONS}

PAGE

Config. 1: R-F Pump Flow Rate Calibration Valve Configuration $\ldots \ldots \ldots \ldots \ldots$

Config. 2: R-F Subassembly Forward Feed Valving Configuration . . . . . . . . . . 12

Config. 3: R-F Subassembly Column 1 Reverse Feed Valving Configuration . . . . . 12

Config. 4: R-F Subassembly Column 2 Reverse Feed Valving Configuration . . . . . 13

Config. 5: CST Pump Flow Rate Calibration Valve Configuration . . . . . . . . . . 14

Config. 6: CST Subassembly Forward Feed Valving Configuration . . . . . . . . . 15

Config. 7: CST Subassembly Column 3 Reverse Feed Valving Configuration . . . . . 16

Config. 8: CST Subassembly Column 4 Reverse Feed Valving Configuration . . . . . 17 
WHC-SD-RE-TPI-001, Rev. 0

THIS PAGE INTENTIONALLY LEFT BLANK 


\section{Test Procedures and Instructions for Hanford Tank Waste Supernatant Cesium Removal}

\subsection{INTRODUCTION}

Cesium-137 $\left.{ }^{137} \mathrm{Cs}\right)$ is a primary radiation source in the dissolved tank waste at the Hanford Site. ${ }^{137} \mathrm{Cs}$ removal from the waste can reduce the hazard and waste classification of the low level waste and reduce treatment and disposal costs.

The cbject of these test procedures is to conduct a test of cesium sorption of actual Hanford tank waste with materials which have been proposed for development and potential deployment in Hanford Site waste treatment. Treated effluent from these tests is proposed to be received by Battelle Pacific Northwest National Laboratory to conduct technetium sorption studies in further support of site waste treatment needs.

These procedures are written to directly meet the procedural needs of the Hanford Tank Waste' Supernatant Cesium Removal Test Plan (Hendrickson and Duncan 1996) to ensure adequacy of conduct and capture of appropriate samples and data.

This 'work is funded by the U.S. Department of Energy's (DOE) Office of Science and Techrology under FY1996 technical task plan RL46WT41 Cesium Removal Tests Using Hanford DSSF Supernatants.

\subsection{DESCRIPTION OF TEST}

For this cesium ion exchange test, a test apparatus will be constructed, functionally tested, then placed in a hot cell within the 222-S Laboratory. Approximately four and one-half liters of dra.inable Double-Shell Slurry Feed (DSSF) supernatant liquor from Hanford Tank 241-A.W-101 will be acquired through the sampling efforts of the TWRS Characterization Project at Hanford (Benar 1996) and will be placed in the hot cell with the test apparatus. The DSSSF supernatant liquor will be diluted with water to a concentration target of five molar sodium, mixed, settled, decanted, and centrifuged to remove particles, and then placed in the feed tank(s) to be used as the feed for the column flow tests.

The test apparatus will contain two test columns and two scavenging (guard) columns. One test column will be packed with crystalline silicotitanate (CST) and the other with Resorcinol-Formaldehyde (R-F). The scavenging columns, packed with the same materials, will be used to reduce any cesium remaining in the effluent. The effluent is intended to be provided to subsequent Tanks Focus Area (TFA) tasks which will require the material for 
techrietium (Tc) removal studies. A sketch of the process flows and instrumentation is

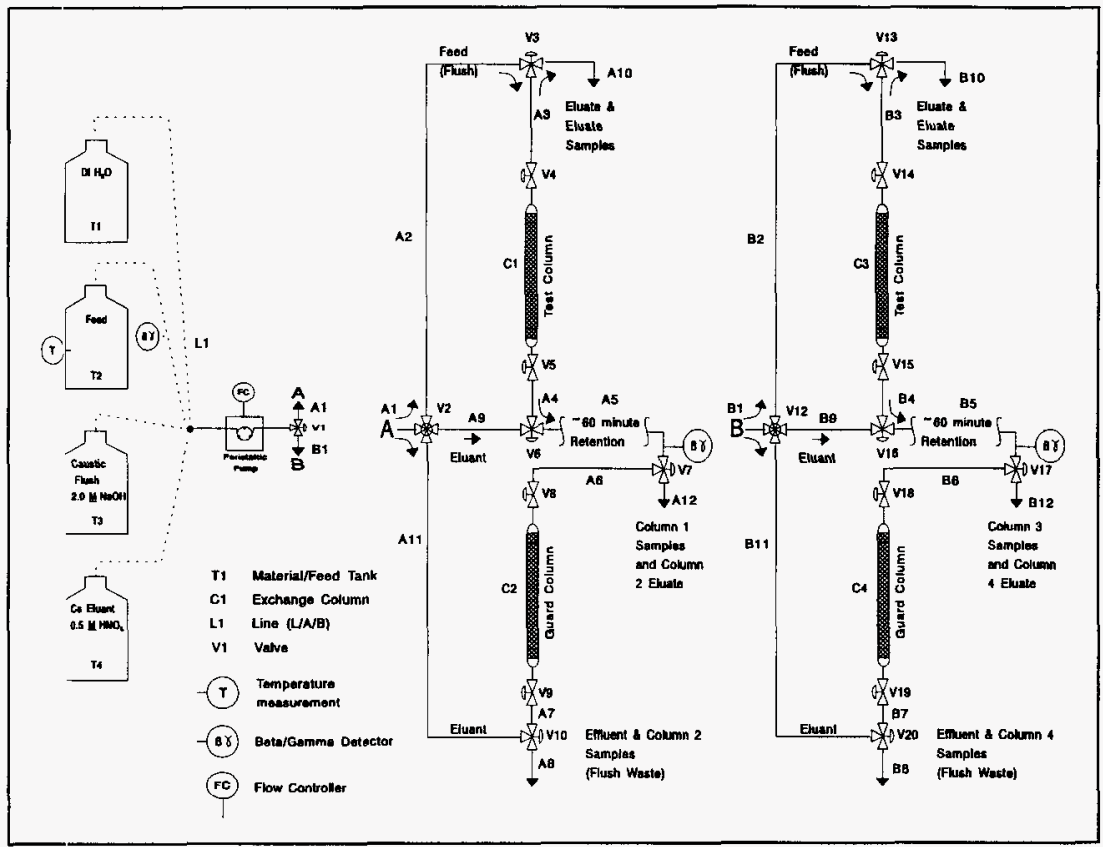

Figure 1: Bench-Scale Cesium Exchange Flows and Instrumentation

provided in Figure 1. Physical layout of the test apparatus is provided in Figure 2.

During the loading phase of the column test, the feed solution will be pumped from the feed tank downward through a test column of cesium sorbent. The effluent from the test column will be monitored for cesium breakthrough and will be sampled periodically. Samples will also be taken of the feed, guard column effluent, digested resin, and the eluate as necessary. Sample analysis, as available, will be performed to determine the concentration of analytes to which the cesium ion exchange and vitrification processes are sensitive. These analytes include: cesium-137, total cesium, strontium, sodium, potassium, rubidium, aluminum, phosphorus (for -phosphate), chromium, and iron as well as the $\mathrm{pH}$ of the sample. The feed temperatures will be recorded at the beginning and during the test.

After cesium breakthrough is detected in the R-F test column, the R-F column will be flushed and the cesium will be eluted from the R-F. After cesium breakthrough is detected in the CST test column, the CST column will be flushed and drained, removed from the system, digested, sampled, and disposed. Initial plans for the cesium sorbent materials are in-ce.l digestion and disposal due to the high shielding requirements and limited capacity of 
manipulators entailed with removal from the hot cell (Hendrickson and Duncan 1996).

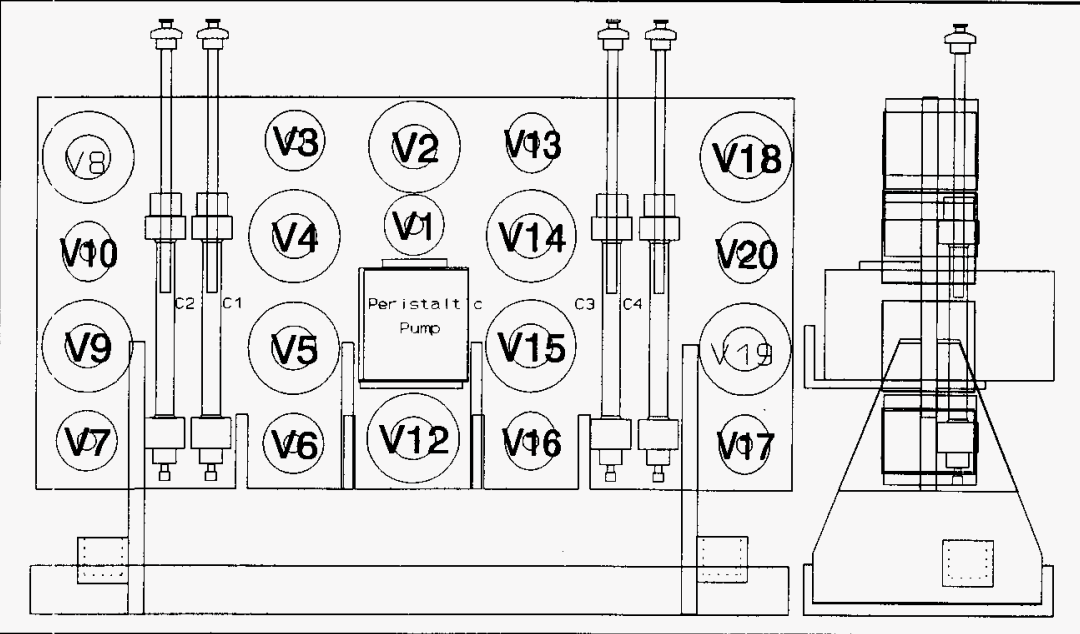

Figure 2: Physical Test Assembly Valve and Column Arrangement

The performance of the sorbents in the removal of cesium from DSSF, and process considerations of such removal, will be evaluated and reported in a final report.

\subsection{TEST ENVIRONMENT}

The test environment is primarily that of the WHC operated 222-S analytical laboratories.

During assembly and acceptance testing of the exchange equipment, assembly is largely antic.pated to occur in the $306 \mathrm{E}$ laboratories (300 Area) and acceptance testing in nonradioactive portions of the 222-S laboratories (building 222-SA). The exchange equipment will be placed into a high-radiation hot cell (1F) of the 222-S laboratory where the process tests will occur.

Waste material core samples, retrieved from tank farms will be brought into the 222-S laboratory and extruded in-cell -11A. Smaller sample bottles (polyethylene) of the waste supernatant liquor will be transferred from cell $11 \mathrm{~A}$ to cell $1 \mathrm{~F}$ for the test work.

With the exception of sample analyses at the 222-S laboratory or the Battelle Pacific Northwest National Laboratory 325 laboratory, the remainder of work will be done within the $1 \mathrm{~F}$ hot cell at $222-\mathrm{S}$. 


\subsection{EQUIPMENT AND FACILITIES}

Equijment needed for the apparatus assembly includes:

4 Exchange Columns, $1 \mathrm{~cm}$ internal diameter (ID), packing height $10 \mathrm{~cm}$, glass walled

8 column clamps for extraction column retention

1 Peristaltic pump, flow range from 15 to $80 \mathrm{~mL} / \mathrm{hr}$

8 gate valves, $\sim 3 \mathrm{~mm} \mathrm{ID}$, Teflon ${ }^{1}$ core

9 three way valves, $\sim 3 \mathrm{~mm}$ ID, Teflon core

2 four way valves, $\sim 3 \mathrm{~mm}$ ID, Teflon core

$5 \mathrm{~m} \quad$ Tygon ${ }^{2}$ tubing, $\sim 0.89,1.59 \mathrm{~mm}, 3.175 \mathrm{~mm}$, and $4.76 \mathrm{~mm}$ ID

1 Feed Reagent Tanks, polyethylene, $1 \mathrm{~L}\left(0.5 \underline{\mathrm{M}} \mathrm{HNO}_{3}\right)$

2 Feed Reagent Tank, polyethylene, $2 \mathrm{~L}$ (waste feed and $\mathrm{H}_{2} \mathrm{O}$ )

1 Feed Reagent Tank, polyethylene, $500 \mathrm{~mL}(2.5 \underline{\mathrm{M} \mathrm{NaOH}})$

9 Effluent Receivers, polyethylene, $2 \mathrm{~L}$

1 Flush receiver, polyethylene, $250 \mathrm{~mL}$

1 Eluant receiver, polyethylene, $250 \mathrm{~mL}$

1 Shears for cutting large feed reagent tanks

75 Glass/polyethylene sample vials with stoppers, $15 \mathrm{~mL}$

12 Centrifuge cones, glass, $50 \mathrm{~mL}$

2 sample vial holders

1 Continuous $\beta / \gamma$ detector and recorder

1 thermometer

1 Test/sample clock

25 R-F resin, grams (MSDS in Appendix B)

40 CST engineered exchange material, grams (MSDS in Appendix B)

Reagents required (for material safety data sheets, see Appendix B), and anticipated volumes include:

$\begin{array}{lll}\text { Deionized Water } & 5.5-7.5 & \text { Liters } \\ \text { Sodium Hydroxide }(\mathrm{NaOH}), 2.5 \underline{\mathrm{M}} & 1.0 & \text { Liters } \\ \text { Nitric Acid }\left(\mathrm{HNO}_{3}\right), 0.5 \underline{\mathrm{M}} & 0.15 & \text { Liters } \\ \text { Nitric Acid }\left(\mathrm{HNO}_{3}\right), 3.0 \underline{\mathrm{M}} & 0.2 & \text { Liters } \\ \text { Hydrofluoric Acid }(\mathrm{HF}), \underline{\mathrm{M}} & 0.1 & \text { Liters } \\ \text { Hydrochloric Acid }(\mathrm{HCl}), 2 \underline{\mathrm{M}} & 0.2 & \text { Liters } \\ \text { Tank Waste, 241-AW-101 } & 4.5 & \text { Liters }\end{array}$

Facilities required are those of the 222-S laboratory $1 \mathrm{~F}$ hot cell, and nonradioactive portions of 222-S and 306E for equipment assembly and acceptance testing.

1 Teflon is a trademark of E. I. duPont de Nemours, Co., Wilmington, DE.

2 Tygon is a trademark of Norton Performance Plastics, Akron, OH. 
WHC-SD-RE-TPI-001, Rev. 0

Table 1: Reagent Densities at Experimental Temperature

\begin{tabular}{||l|r|r||}
\hline Reagent & mol/L & $\begin{array}{c}\text { Density } \\
(\mathrm{g} / \mathrm{mL}) 27^{\circ} \mathrm{C}\end{array}$ \\
\hline $\mathrm{HF}$ & 1 & 0.998118 \\
\hline $\mathrm{HCl}$ & 2 & 1.030655 \\
\hline $\mathrm{H}_{2} \mathrm{O}$ & 55.51 & 0.996513 \\
\hline $\mathrm{HNO}_{3}$ & 3 & 1.09902 \\
\hline $\mathrm{HNO}_{3}$ & 0.5 & 1.017293 \\
\hline $\mathrm{NaOH}$ & 2.5 & 1.042449 \\
\hline
\end{tabular}

Source: Perry's Chemical Engineer's Handbook, Sixth Edition, R.H.Perry, D. W. Green, J. O. Maloney, McGraw-Hill Book Company, New York, New York, 1984.

Additional or differing equipment and reagents may be applied at the discretion of operating personnel with concurrence of the lead chemist or engineer. Change procedures are provided in $\S 5.0$. A detail of equipment and reagents used in conduct will be provided in the test report.

\subsection{DATA}

Paraneters to be measured, and the precision required is, in large part, defined by the test subtask. In general, the parameters of measurement, when not in chemical assay, are those of interval, volume, mass, and beta/gamma decay. The subtasks to be described and executed herein are waste feed preparation exchange column packing, activation, flush, opera.tion, sampling, elution, and waste material handling. Chemical assay quality assurance is described by Meznarich (1995). Data acquisition and handling particular to this test will be defined within the Quality Assurance project Plan written to support this test. Data Sheets and checksheets for operation are provided in Appendix A. Completed datasheets and checksheets will be entered into appropriate logbooks. 222-S chemical assay analyses will be stored in the Laboratory Information Management System.

\subsection{CRITERIA/CONSTRAINTS}

The nature of this test is that of a treatability test. As such, the activities encompassed within this test are governed by WAC 173-303-071(3)(r) [Treatability Study Samples] and WAC: 173-303-071(3)(s) [Samples undergoing treatability studies at laboratories and testing facilities] thereby generating a requirement that the Washington State Department of Ecology (WDOE) be notified, in writing, of the intent to conduct treatability studies no less than 45 days prior to conducting the studies. Treatment of actual waste in the test apparatus shall not proceed unless such a notice compliant with WAC 173-303-071(s)(i) is submitted. (WDOE 1994) As described by the test plan (Hendrickson and Duncan 1996), compliance with these provisions has been met with 1988 notification. 
ALARA principles must guide all actions in this test.

\subsection{WASTE MANAGEMENT AND DISPOSAL}

Wastes from the conduct of this test scope will include extraction media, extraction columns, sample bottles, feed bottles (tanks), tygon tubing, valves, waste liquor, treatment effluent and eluart, and sampling wastes. All materials having contacted the tank waste liquor must be considered mixed wastes as the tank wastes have been designated to contain F-listed solvents (EPA. 1986). To the greatest extent possible, bottles containing wastes brought into the hot cell will be of polyethylene so that they may be melted down within the cell following use. The extraction media will be dissolved, sampled, and slurped (poured down hot cell drain). Eluants, excess and spent samples, and undispositioned effluent will be slurped. Glass vessels will be decontaminated and removed from the cell for appropriate waste disposal.

Although there has been some consideration for further application of the extraction media, preliminary dose models (Hendrickson and Duncan 1996) indicate that shielding sufficient to reduce dose to the $222-S$ laboratory administrative requirement of $10 \mathrm{mR} / \mathrm{hr}$ would exceed the $18 \mathrm{~kg}(40 \mathrm{lb})$ capacity of the cell manipulators. As such, it cannot be considered safe to remove these materials from the hot cell intact. Further, preliminary calculations would indicate that achievable removals within the manipulator capacity would not significantly excesd one percent of the loaded CST column $(\sim 60 \mathrm{mg})$ with each loadout. These minute removal capabilities are not considered economically or technically justifiable.

\subsection{EXPECTED RESULTS}

This test will demonstrate the cesium selectivity and load capacity of CST and R-F using actual Hanford DSSF waste. This information will be compared to similar data gathered using simulants and will be used to validate the simulant data's use in the designing of a cesium removal pretreatment process.

Success of these tests will be in the form of chemical analysis and automatic beta/gamma sample counts demonstrating rise in concentration of the effluent cesium beyond $50 \%$ of inlet concentration (breakthrough, $\lambda_{s_{0}}$ ) such that the number of column volumes processed at break.through be determinable on a constant slope.

Prior development of these sorption materials has indicated that treatment expectations for the R-F resin may vary from 30 to 65 column volumes of waste feed to $\lambda_{50}$ while the CST treatment may vary from 300 to 800 column volumes of waste feed to $\lambda_{50}$. Due to the wide rangs: of these expectations, on-line beta-gamma detection capability will be required to ensure adequate sampling to describe the effluent profile. 


\subsection{TEST PROCEDURE}

This test procedure is partitioned into four primary subdivisions: system acceptance testing and calibration; Resorcinol-Formaldehyde test run preparation, load and elution; crystalline silicotitanate test run preparation, load and elution; system flush, decontamination, and waste management. Sampling procedures are a component of each of these subdivisions of the test and are provided as a fifth component of the test.

Laboratory instruction, as necessary will be developed to implement these laboratory 222-S procedures.

Initiai pump calibration and subassembly resin conditioning will be conducted in nonradiologically contaminated conditions. Thus portions of test conduct through conditioning $(\$ \$ 4.2 .2$ and 4.3.2) will be conducted serially prior to hot cell entry of the assembly. Subsequent work will be conducted in the sequence specified by this document unless modified through change procedure $(\$ 5.0)$. All checksheets and data sheets are provided in Appendix A.

\subsection{SYSTEM ACCEPTANCE TESTING AND CALIBRATIONS}

The flow system apparatus (apparatus is defined as the entire system to include pumps, valving, plumbing, and columns without the exchange material) will be assembled in the nonradiological WHC laboratories in the 300 Area.

The valving, piping, tubing, columns, and exchange material will be the same that will be used in the hot cell in 222-S laboratory and shall follow the schematic as shown in Figure 1. Physizal layout is depicted in Figure 2. The assembly of the apparatus in a cold area will also entail test run preparations of loading and conditioning of the exchange material in the respective columns as per manufacturer's specifications. With the exception of $\S 4.1 .5$, these acceptance testing and calibration activities will be nonradiological activities.

\subsubsection{Equipment Assembly}

Equipment assembly consists of assembling the tubing, fittings, valves, pump and columns to meet the test needs. Specification of assembly is composed of feed assembly, RF test assembly, and CST test assembly. Fabrication of the substrate and basin of the test apparatus is conducted separately and prior to this assembly. Checksheets and assembly instructions are provided in Appendix A.

\subsubsection{Feed Assembly}

The ion exchange columns will be loaded and the RF and CST resins conditioned before tank waste supernatant liquor challenge. The conditioning will be accomplished as outlined in sections 4.2.2 (RF) and 4.3.2 (CST).

The feed bottles, composed of polyethylene, for deionized water (T1), tank supernatant 
liquor (T2), $2.5 \underline{\mathrm{M} \mathrm{NaOH}}$ (caustic flush, T3), and $0.5 \underline{\mathrm{M}} \mathrm{HNO}_{3}$ (Cs eluant, T4) will share one line (L1) to the peristaltic pump (Figure 1). The discharge line from the peristaltic pump will connect to a three connection valve (V1). The line diameter selected for the pump mid-range has an ID of $0.89 \mathrm{~mm}$. There will be two lines connected from V1 to the test colurnns, the $\mathrm{A} 1$ line to the RF columns and the B1 line to the CST columns.

No assembly is required for the feed tanks, thus feed assembly shall consist of assembling line $L 1$ and mounting it through the pump and to valve V1. Use Sheet 1 for feed assembly directions, imagery, and checksheet.

\subsubsection{RF Test Assembly}

The R-F test subassembly shall be completed using Sheet 2 . The function of all valve configurations are detailed in Table 2.

The object of the subassembly is to provide feed liquors from the primary distribution valve V1 through distribution and isolation valves in configurations allowing flow and flush in each direction through the test and guard columns to sample and effluent points.

\subsubsection{CST Test Assembly}

The CST test subassembly shall be completed using Sheet 3 . The function of all valve configurations are detailed in Table 3.

The object of the subassembly is to provide feed liquors from the primary distribution valve V1 through distribution and isolation valves in configurations allowing flow and flush in each direction through the test and guard columns to sample and effluent points.

\subsubsection{Leak Testing in Cold Environment}

Using Figure 1 as a reference for flow streams and Figure 2 as reference for physical layout, the following steps will be carried out to cold test the system in Building 306E. Care should be taken to try and anticipate problems that may arise during the operation in a hot cell.

This will allow a "fix it" mode to be undertaken in a non-radiation area. The resin will not be loaded in the columns for this portion of the test. Record conduct through indicated checksheets and datasheets.

The system will be challenged with deionized (DI) water for this phase. The connecting lines are the required ID and length and the valving is connected as indicated in Table 2 and Table 3 . An additional objective of this portion of the test is system displacement volume measurement; for this reason, collected liquids and flow times are recorded.

\subsubsection{RF Subassembly Leak Testing}

\subsection{Pump Set}


WHC-SD-RE-TPI-001, Rev. 0

Table 2: Valve Connection/Function for R-F Resin Columns

\begin{tabular}{|c|c|c|c|}
\hline Valve & After & Before & Function \\
\hline \multirow{2}{*}{ V1 } & \multirow{2}{*}{$\begin{array}{l}\text { Peristaltic } \\
\text { Pump }\end{array}$} & $\mathrm{V} 2$ & Connects pump to Test bed A \\
\hline & & $\mathrm{V} 12$ & Connects pump to Test bed B \\
\hline \multirow{3}{*}{$\mathrm{V} 2$} & \multirow{3}{*}{ V1 } & v3 & Directs Feed to C1 \\
\hline & & V6 & Directs eluant to $\mathrm{C} 1$ \\
\hline & & $\mathrm{V} 10$ & Directs eluant to $\mathrm{C} 2$ \\
\hline \multirow[b]{2}{*}{ V3 } & V2 & V4 & Directs Feed to $\mathrm{Cl}$ \\
\hline & V4 & NA & $\begin{array}{l}\text { Eluate from } \mathrm{C2} \text { and } \\
\text { eluate samples }\end{array}$ \\
\hline \multirow{2}{*}{ V4 } & V3 & $\mathrm{Cl}$ & Column Isolation, Forward \\
\hline & $\mathrm{C} 1$ & V3 & Column Isolation, Reverse \\
\hline \multirow{2}{*}{ V5 } & $\mathrm{C} 1$ & V6 & Column Isolation, Forward \\
\hline & V6 & $\mathrm{Cl}$ & Column Isolation, Reverse \\
\hline \multirow[t]{2}{*}{ V6 } & V5 & $\begin{array}{l}60 \text { min retention } \\
\text { line w/ } \\
\text { beta/gamma and } \\
\text { V7 }\end{array}$ & Directs $\mathrm{Cl}$ effluent to $\mathrm{V} 7$ \\
\hline & $\mathrm{V} 2$ & C1 & Directs eluant into $\mathrm{C} 1$ \\
\hline \multirow{3}{*}{ V7 } & \multirow{2}{*}{ V6 } & V8 & $\mathrm{C} 1$ Flow to $\mathrm{C} 2$ \\
\hline & & NA & C1 effluent samples \\
\hline & V8 & NA & C2 eluate flow \\
\hline \multirow{2}{*}{ V8 } & V7 & $\mathrm{C} 2$ & Column Isolation, Forward \\
\hline & $\mathrm{C} 2$ & V7 & Column Isolation, Reverse \\
\hline \multirow{2}{*}{ V9 } & $\mathrm{C} 2$ & V10 & Column Isolation, Forward \\
\hline & $\mathrm{V} 10$ & $\mathrm{C} 2$ & Column Isolation, Reverse \\
\hline \multirow{3}{*}{ V 10} & V9 & NA & Directs eftluent from $\mathrm{C} 2$ to receiver \\
\hline & \multirow{2}{*}{$\mathrm{V} 2$} & V9 & Directs eluant to $\mathrm{C} 2$ \\
\hline & & NA & Line flush to waste \\
\hline
\end{tabular}

NA $=$ not applicable, flow to receiver.

The peristaltic pump does not have a digital readout or record. Calibration will be conducted with each flow rate change and recorded on Sheet 4 as required by each procedure. The flow path (Config. 1) for calibration will be: 
Conlig. 1: R-F Pump Flow Rate Calibration Valve Configuration

WHC-SD-RE-TPI-001, Rev. 0

\begin{tabular}{||l|l|l||}
\hline \hline Valve & Position & Direction \\
\hline V1 & Open & L1 $\rightarrow$ V1 $\rightarrow$ A1 \\
\hline V2 & Open & A1 $\rightarrow$ V2 $\rightarrow$ A2 \\
\hline V3 & Open & A2 $\rightarrow$ V3 $\rightarrow$ A10 \\
\hline
\end{tabular}

\section{ALL VALVING CONFIGURATIONS REQUIRE THAT ALL VALVES NOT SPECIFIED AS OPEN SHALL BE CLOSED}

Use Sheet 4 to record and conduct this procedure.

Objective: $4 \mathrm{CV} / \mathrm{hr}=31.4 \mathrm{~mL} / \mathrm{hr}=31.4 \mathrm{~g} / \mathrm{hr}\left(\mathrm{DI} \mathrm{H}_{2} \mathrm{O}\right)$

- Tare receiver bottle $(\sim 100 \mathrm{~mL}$ capacity $)$

- Place line L1 into T1 (DI $\left.\mathrm{H}_{2} \mathrm{O}\right)$. Place Line A10 into tared receiver.

- Set valve positions to: Config. 1

- Set flow rate - turn on pump, measure for $15 \mathrm{~min}$. Check against objective, record results.

- Reset to get to objective as necessary, repeat.

- When at objective, confirm flow with two more test periods.

- Shut down the pump.

- Close and confirm closure of all valves.

\subsection{Column Forward Tests}

Use Sheet 5 to record and conduct this procedure.

- Tare receiver bottle $(\sim 100 \mathrm{~mL}$ capacity)

- Place line L1 into feed vessel T1, place line A8 into tared receiver

- Set valve positions to: Config. 2.

- After ensuring the flow path is correct to the above valve settings, turn on the peristaltic pump. For the RF exchanger, $4 \mathrm{CV} / \mathrm{hr}$ are targeted which is approximately $0.5 \mathrm{~mL} / \mathrm{min}$ or $31 \mathrm{~mL} / \mathrm{hr}$. Run in this eonfiguration for 3 -hours.

- If leaks are observed, adjust fittings as necessary to eliminate leaks. Record observations and leak repairs.

- After the appropriate time period for leak testing in a forward flow mode, shut down the pump. Record masses recovered and time interval on Sheet 5 .

\subsection{Column Reverse Flow Tests}


WHC-SD-RE-TPI-001, Rev. 0

Table 3: Valve Connection/Function for CST Resin Columns

\begin{tabular}{|c|c|c|c|}
\hline Valve & After & Before & Function \\
\hline \multirow{2}{*}{ V1 } & \multirow{2}{*}{$\begin{array}{l}\text { Peristaltic } \\
\text { Pump }\end{array}$} & $\mathrm{V} 2$ & Connects pump to Test bed A \\
\hline & & V12 & Connects pump to Test bed B \\
\hline \multirow{3}{*}{ V12 } & \multirow{3}{*}{ V1 } & V13 & Directs Feed to C3 \\
\hline & & V16 & Directs eluant to $\mathrm{C} 3$ \\
\hline & & $\mathrm{V} 20$ & Directs eluant to C4 \\
\hline \multirow[b]{2}{*}{ V13 } & $\mathrm{V} 12$ & V14 & Directs Feed to C3 \\
\hline & V14 & $\mathrm{NA}$ & $\begin{array}{l}\text { Eluate from C4 and } \\
\text { eluate samples }\end{array}$ \\
\hline \multirow{2}{*}{$\mathrm{V} 14$} & V13 & $\mathrm{C} 3$ & Column Isolation, Forward \\
\hline & $\mathrm{C} 3$ & V13 & Column Isolation, Reverse \\
\hline \multirow{2}{*}{ V15 } & $\mathrm{C3}$ & $\mathrm{V} 16$ & Column Isolation, Forward \\
\hline & V16 & $\mathrm{C} 3$ & Column Isolation, Reverse \\
\hline \multirow[t]{2}{*}{ V16 } & $\mathrm{V} 15$ & $\begin{array}{l}60 \text { min retention } \\
\text { line w/ } \\
\text { beta/gamma and } \\
\text { V } 17\end{array}$ & Directs C3 effluent to V17 \\
\hline & $\mathrm{V} 12$ & $\mathrm{C} 3$ & Directs eluant into $\mathbf{C 1}$ \\
\hline \multirow{3}{*}{ V17 } & \multirow{2}{*}{ V16 } & V18 & C3 Flow to C4 \\
\hline & & NA & C3 etfluent samples \\
\hline & $\mathrm{V} 18$ & NA & C4 eluate flow \\
\hline \multirow{2}{*}{ V18 } & V17 & $\mathrm{C} 4$ & Column Isolation, Forward \\
\hline & $\mathrm{C4}$ & V7 & Column Isolation, Reverse \\
\hline \multirow{2}{*}{ V19 } & $\mathrm{C} 4$ & $\mathrm{~V} 10$ & Column Isolation, Forward \\
\hline & $\mathrm{V} 20$ & $\mathrm{C} 4$ & Column Isolation, Reverse \\
\hline \multirow{3}{*}{$\mathrm{V} 20$} & V19 & NA & Directs effluent from $\mathrm{C} 4$ to receiver \\
\hline & \multirow{2}{*}{ V12 } & V9 & Directs eluant to $\mathrm{C} 4$ \\
\hline & & NA & Line flush to waste \\
\hline
\end{tabular}

$\mathrm{NA}=$ Not Applicable, flow to receiver vessel

\subsection{Column 1 Elution Leak Test}

Use Sheet 6 to record and conduct this procedure.

- Tare receiver bottle $(\sim 100 \mathrm{~mL}$ capacity $)$ 
Config. 2: R-F Subassembly Forward Feed Valving Configuration

WHC-SD-RE-TPI-001, Rev. 0

\begin{tabular}{|l|l|l|}
\hline Valve & Position & Direction \\
\hline V1 & Open & L1 $\rightarrow$ V1 $\rightarrow$ A1 \\
\hline V2 & Open & A1 $\rightarrow$ V2 $\rightarrow$ A2 \\
\hline V3 & Open & A2 $\rightarrow$ V3 $\rightarrow$ A3 \\
\hline V4 & Open & A3 $\rightarrow$ V4 $\rightarrow$ C1 \\
\hline V5 & Open & C1 $\rightarrow$ V5 $\rightarrow$ A4 \\
\hline V6 & Open & A4 $\rightarrow$ V6 $\rightarrow$ A5 \\
\hline V7 & Open & A5 $\rightarrow$ V7 $\rightarrow$ A6 \\
\hline V8 & Open & A6 $\rightarrow$ V8 $\rightarrow$ C2 \\
\hline V9 & Open & C2 $\rightarrow$ V9 $\rightarrow$ A7 \\
\hline V10 & Open & A7 $\rightarrow$ V10 $\rightarrow$ A8 \\
\hline
\end{tabular}

- Place line L1 into feed vessel T1, place line A10 into tared receiver

- Set valve positions to: Config. 3:

Config. 3: R-F Subassembly Column 1 Reverse Feed Valving Configuration

\begin{tabular}{|l|l|l|}
\hline Valve & Position & Direction \\
\hline V1 & Open & L1 $\rightarrow$ V1 $\rightarrow$ A1 \\
\hline V2 & Open & A1 $\rightarrow$ V2 $\rightarrow$ A9 \\
\hline V6 & Open & A9 $\rightarrow$ V6 $\rightarrow$ A4 \\
\hline V5 & Open & A4 $\rightarrow$ V5 $\rightarrow$ C1 \\
\hline V4 & Open & C1 $\rightarrow$ V4 $\rightarrow$ A3 \\
\hline V3 & Open & A3 $\rightarrow$ V3 $\rightarrow$ A10 \\
\hline
\end{tabular}

- After ensuring the flow path is correct to the above valve settings, turn on the peristaltic pump. For the RF exchanger, $4 \mathrm{CV} / \mathrm{hr}$ are targeted which is approximately $0.5 \mathrm{~mL} / \mathrm{min}$ or $31 \mathrm{~mL} / \mathrm{hr}$. Run in this configuration for 1 hour.

- If leaks are observed, adjust fittings as necessary to eliminate leaks. Record observations and leak repairs.

- After the appropriate time period for leak testing in a reverse flow mode, shut down 
the pump. Record masses recovered and time interval on Sheet 6 .

\subsection{Column 2 Elution Leak Test}

Use Sheet 7 to record and conduct this procedure.

- Tare receiver bottle $(\sim 100 \mathrm{~mL}$ capacity $)$

- Place line $\mathrm{L} 1$ in feed vessel T1, place line A12 into tared receiver

- Set valves positions to: Config. 4:

Config. 4: R-F Subassembly Column 2 Reverse Feed Valving Configuration

\begin{tabular}{|l|l|l|}
\hline Valve & Position & Direction \\
\hline V1 & Open & L1 $\rightarrow \mathrm{V} 1 \rightarrow \mathrm{A} 1$ \\
\hline V2 & Open & A1 $\rightarrow$ V2 $\rightarrow$ A11 \\
\hline V10 & Open & A11 $\rightarrow$ V10 $\rightarrow$ A7 \\
\hline V9 & Open & A7 $\rightarrow$ V9 $\rightarrow$ C2 \\
\hline V8 & Open & C2 $\rightarrow$ V8 $\rightarrow$ A6 \\
\hline V7 & Open & A6 $\rightarrow \mathrm{V} 7 \rightarrow$ A12 \\
\hline
\end{tabular}

- After ensuring the flow path is correct to the above valve settings, turn on the peristaltic pump. For the RF exchanger, $4 \mathrm{CV} / \mathrm{hr}$ are targeted which is approximately $0.5 \mathrm{~mL} / \mathrm{min}$ or $31 \mathrm{~mL} / \mathrm{hr}$. Run in this configuration for 1 hour.

- If leaks are observed, adjust fittings as necessary to eliminate leaks. Record observations and leak repairs.

- After the appropriate time period for leak testing in a reverse flow mode, shut down the pump. Record masses recovered and time interval on Sheet 7. 


\subsubsection{CST Subassembly Leak Test}

\subsection{Pump Set}

The peristaltic pump does not have a digital readout or record. Calibration will be conducted with each flow rate change and recorded on Sheet 11 as required by each procedure. The flow path (Config. 5) for calibration will be:

Config. 5: CST Pump Flow Rate Calibration Valve Configuration

\begin{tabular}{||l|l|l|}
\hline \hline Valve & Position & Direction \\
\hline V1 & Open & L1 $\rightarrow$ V1 $\rightarrow$ B1 \\
\hline V12 & Open & B1 $\rightarrow$ V12 $\rightarrow$ B2 \\
\hline V13 & Open & B2 $\rightarrow$ V13 $\rightarrow$ B10 \\
\hline
\end{tabular}

Use Sheet 11 to record and conduct this procedure.

Objective: $6 \mathrm{CV} / \mathrm{hr}=47.1 \mathrm{~mL} / \mathrm{hr}=47.1 \mathrm{~g} / \mathrm{hr}\left(\mathrm{DI} \mathrm{H} \mathrm{H}_{2} \mathrm{O}\right)$

- Tare receiver bottle $(\sim 100 \mathrm{~mL}$ capacity $)$

- Place line L1 into T1. Place Line B10 into tared receiver.

- Set valve positions to: Config. 5

- Set flow rate - turn on pump, measure for 15 min. Check against objective, record results.

- Reset to get to objective as necessary, repeat.

- When at objective, confirm flow with two more test periods.

- Shut down the pump.

- Close and confirm closure of all valves.

\subsection{Column Forward Tests}

Use Sheet 12 to record and conduct this procedure.

- Tare receiver bottle $(100 \mathrm{~mL}<$ receiver $<250 \mathrm{~mL})$

- Place L1 into feed vessel T1, place line B8 into tared receiver

- Set valve positions to: Config. 6 .

- After ensuring the flow path is correct to the above valve settings, turn on the peristaltic pump. For the CST exchanger, $6 \mathrm{CV} / \mathrm{hr}$ are targeted which is approximately $0.8 \mathrm{~mL} / \mathrm{min}$ or $47.1 \mathrm{~mL} / \mathrm{hr}$. Run in this configuration for 3 hours.

- If leaks are observed, adjust fittings as necessary to eliminate leaks. Record observations and leak repairs. 
WHC-SD-RE-TPI-001, Rev. 0

Config. 6: CST Subassembly Forward Feed Valving Configuration

\begin{tabular}{|l|l|l|}
\hline Valve & Position & Direction \\
\hline V1 & Open & L1 $\rightarrow$ V1 $\rightarrow$ B1 \\
\hline V12 & Open & B1 $\rightarrow$ V12 $\rightarrow$ B2 \\
\hline V13 & Open & B2 $\rightarrow$ V13 $\rightarrow$ B3 \\
\hline V14 & Open & B3 $\rightarrow$ V14 $\rightarrow$ C3 \\
\hline V15 & Open & C3 $\rightarrow$ V15 $\rightarrow$ B4 \\
\hline V16 & Open & B4 $\rightarrow$ V16 $\rightarrow$ B5 \\
\hline V17 & Open & B5 $\rightarrow$ V17 $\rightarrow$ B6 \\
\hline V18 & Open & B6 $\rightarrow$ V18 $\rightarrow$ C4 \\
\hline V19 & Open & C4 $\rightarrow$ V19 $\rightarrow$ B7 \\
\hline V20 & Open & B7 $\rightarrow$ V20 $\rightarrow$ B8 \\
\hline
\end{tabular}

- After the appropriate time period for leak testing in a reverse flow mode, shut down the pump. Record masses recovered and time interval on Sheet 12 . 


\subsection{Column Reverse Flow Tests}

\subsection{Column 3 Elution Leak Test}

Use Sheet 13 to record and conduct this procedure.

- Tare receiver bottle $(\sim 100 \mathrm{~mL})$

- Place line L1 in feed vessel T1, place line B10 into tared receiver

- Set valve positions to: Config. 7:

Conlig. 7: CST Subassembly Column 3 Reverse Feed Valving Configuration

\begin{tabular}{|l|l|l|}
\hline Valve & Position & Direction \\
\hline V1 & Open & L1 $\rightarrow$ V1 $\rightarrow$ B1 \\
\hline V12 & Open & B1 $\rightarrow$ V12 $\rightarrow$ B9 \\
\hline V16 & Open & B9 $\rightarrow$ V16 $\rightarrow$ B4 \\
\hline V15 & Open & B4 $\rightarrow$ V15 $\rightarrow$ C3 \\
\hline V14 & Open & C3 $\rightarrow$ V14 $\rightarrow$ B3 \\
\hline V13 & Open & B3 $\rightarrow$ V13 $\rightarrow$ B10 \\
\hline
\end{tabular}

- After ensuring the flow path is correct to the above valve settings, turn on the peristaltic pump. For the CST exchanger, $6 \mathrm{CV} / \mathrm{hr}$ are targeted which is approximately $0.8 \mathrm{~mL} / \mathrm{min}$ or $47.1 \mathrm{~mL} / \mathrm{hr}$. Run in this configuration for 1 hour.

- If leaks are observed, adjust fittings as necessary to eliminate leaks. Record observations and leak repairs.

- After the appropriate time period for leak testing in a reverse flow mode, shut down the pump. Record masses recovered and time interval on Sheet 13.

\subsection{Column 4 Elution Leak Test}

Use Sheet 14 to record and conduct this procedure.

- Tare receiver bottle $(\sim 100 \mathrm{~mL})$

- Place line L1 into feed vessel T1, place line B12 into tared receiver

- Set valve positions to: Config. 8:

- After ensuring the flow path is correct to the above valve settings, turn on the peristaltic pump. For the CST exchanger, $6 \mathrm{CV} / \mathrm{hr}$ are targeted which is approximately $0.8 \mathrm{~mL} / \mathrm{min}$ or $47.1 \mathrm{~mL} / \mathrm{hr}$. Run in this configuration for 1 hour.

- If leaks are observed, adjust fittings as necessary to eliminate leaks. Record 
WHC-SD-RE-TPI-001, Rev. 0

Config. 8: CST Subassembly Column 4 Reverse Feed Valving Configuration

\begin{tabular}{|l|l|l|}
\hline Valve & Position & Direction \\
\hline V1 & Open & L1 $\rightarrow$ V1 $\rightarrow$ B1 \\
\hline V12 & Open & B1 $\rightarrow$ V12 $\rightarrow$ B11 \\
\hline V20 & Open & B11 $\rightarrow$ V20 $\rightarrow$ B7 \\
\hline V19 & Open & B7 $\rightarrow$ V19 $\rightarrow$ C4 \\
\hline V18 & Open & C4 $\rightarrow$ V18 $\rightarrow$ B6 \\
\hline V17 & Open & B6 $\rightarrow$ V17 $\rightarrow$ B12 \\
\hline
\end{tabular}

observations and leak repairs.

- After the appropriate time period for leak testing in a reverse flow mode, shut down the pump. Record masses recovered and time interval on Sheet 14.

\subsubsection{Reagent Preparation}

The following reagents shall be prepared by the standards laboratory and delivered to 222-S for hot cell entry as needed:

$\begin{array}{lll}\mathrm{NaOH}, a q . & 2.5 \underline{\mathrm{M}} & 1.0 \mathrm{~L} \\ \mathrm{HF}, a q . & 1.0 \underline{\mathrm{M}} & 100 \mathrm{~mL} \\ \mathrm{HCl}, a q . & 2.0 \underline{\mathrm{M}} & 200 \mathrm{~mL} \\ \mathrm{HNO}_{3}, a q . & 3.0 \underline{\mathrm{M}} & 200 \mathrm{~mL} \\ \mathrm{HNO}_{3}, a q . & 0.5 \underline{\mathrm{M}} & 750 \mathrm{~mL}\end{array}$

Specifications and contaminants of the reagents shall be identified for inclusion in test data analysis.

\subsubsection{Exchange Material Dissolution}

Prio:- to loading the columns with resin, a qualitative evaluation of the dissolution of the resin must be carried out. These dissolutions will be conducted in 222-S nonradiological facilities in a hood with appropriate personal protective equipment. MSDS review is required.

\subsubsection{R-F Resin}

Use Sheet 18 to record and conduct this procedure.

- In an evaporating dish, weigh out $1 \mathrm{~g}$ of $\mathrm{R}-\mathrm{F}$ resin

- Add $2 \mathrm{~mL}$ of $3 \underline{\mathrm{M}} \mathrm{HNO}_{3}$ acid.

- Allow $\sim 1$ hour for digestion, do not heat above $60^{\circ} \mathrm{C}$ 
- Transfer to $100 \mathrm{~mL}$ volumetric flask and dilute with DI water to the mark.

- Subsample $\sim 5 \mathrm{~mL}$ and retain, label the subsample as SRF1.

- Record all observations on Sheet 18.

\subsubsection{CST Resin}

Use Sheet 19 to record and conduct this procedure.

- In an evaporating dish, weigh out $0.1 \mathrm{~g}$ of CST resin

- Add $3 \mathrm{~mL}(+/-0.5 \mathrm{~mL})$ DI water

- Add about $1 \mathrm{~mL}$ of $\mathrm{HCl}(2 \mathrm{M})$

- Add $0.5 \mathrm{~mL}$ of $\mathrm{HF}(1 \underline{\mathrm{M}})$

- Heat gently to dissolve.

- Transfer to $100 \mathrm{~mL}$ volumetric flask and dilute with DI water to the mark.

- Subsample $\sim 5 \mathrm{~mL}$ and retain, label the subsample as SCST1.

- Record all observations on Sheet 19.

NOTE: Due to the proprietary nature of the resin substrate and binder, analytical information from sample analyses of this material will not be publicly released.

\subsubsection{Beta-Gamma Probe Calibration}

The calibration of the beta/gamma probe will be carried out using 222-S laboratory sources, for a range of $9.25 \mathrm{E} 9 \mathrm{~Bq} / \mathrm{L}$ to $9.25 \mathrm{E} 5 \mathrm{~Bq} / \mathrm{L}\left(0.25 \mathrm{Ci} / \mathrm{L}{ }^{137} \mathrm{Cs}\right.$ to $\left.25 \mu \mathrm{Ci} / \mathrm{L}\right)$. The source confi; $;$ uration will be Tygon tubing, $4.76 \mathrm{~mm}$ ID, $9.52 \mathrm{~mm}$ OD. The tubing standard should be about $10 \mathrm{~cm}$ in length. The length of the tubing need only be measured approximately, since previous work (Beck et al. 1996) has shown that the gamma detector is sensitive to cesiun (barium) gammas only in a smail cone $(6 \mathrm{~cm}$ diameter at sample) below the probe. The lower level standard may not be detectable on the time scale used during the tests, as it represents about 1650 disintegrations per minute for the entire standard. Calibration responses from prepared standards will be entered into an appropriate laboratory notebook.

\subsection{R-F TEST PREPARATION AND RUN}

This portion of the test plan is intended to provide explicit instructions and expectations of the conduct of ion exchange with the apparatus using Resorcinol-Formaldehyde. The expectations are that the $50 \%$ breakthrough will be at approximately $62-65$ column volumes $\left(\lambda_{50 \%}=62-65 \mathrm{CV}\right)$, and that the run will be conducted for 80 column volumes, sampled on the first and every 5 column volumes.

\subsubsection{Pump Flow Set}

Use Sheet 4 to record and conduct this procedure.

$$
\text { Object } 10 \mathrm{CV} / \mathrm{hr}=79.6 \mathrm{~mL} / \mathrm{hr}=79.6 \mathrm{~g} / \mathrm{hr} \mathrm{DI} \mathrm{H} \mathrm{H}_{2} \mathrm{O}
$$


- Tare receiver bottle $(\sim 100 \mathrm{~mL}$ capacity)

- Set valve positions to: Config. 1

- Place line L1 into T1 (DI $\mathrm{H}_{2} \mathrm{O}$ ). Place Line A10 into tared receiver.

- Set flow rate - turn on pump, measure for $15 \mathrm{~min}$. Check against objective, record results.

- Reset to get to objective as necessary, repeat.

- When at objective, confirm flow with two more test periods.

- Shut down the pump.

- Close and confirm closure of all valves.

\subsubsection{Exchange Column Preparation}

Both the test column, $\mathrm{C} 1$, and the guard column, $\mathrm{C} 2$, will be charged with $\mathrm{R}-\mathrm{F}$ resin and conditioned outside of the hot cell. After conditioning and pump calibration, the columns and system will be transferred into the hot cell (NOTE: SIMLAR SERIAL WORK IS REQUIRED FOR THE CST SUBASSEMBLY PRIOR TO HOT CELL PLACEMENT).

The resin received is in the potassium form, it must be conditioned by:

- $10 \mathrm{CV} / \mathrm{h}$ of $0.5 \underline{\mathrm{M}} \mathrm{HNO}_{3}, 1$ hour, followed by

- $10 \mathrm{CV} / \mathrm{h}$ of DI water, 1 hour followed by

- $10 \mathrm{CV} / \mathrm{h}$ of $2.5 \underline{\mathrm{M}} \mathrm{NaOH}, 1$ hour.

Use Sheet 24 to prepare and measure the bed density of the resin.

Use Sheet 5(s) to record and conduct these column procedural activities.

- Place Line L1 into T4 $\left(0.5 \underline{\mathrm{M}} \mathrm{HNO}_{3}\right)$.

- Place Line A8 into flush container

- Place System Valving in Config. 2. Confirm and record valving alignment.

- Turn on pump and run for one hour. Record time on/off, flowrate and feed source.

- Rinse feed end of L1 with $\mathrm{H}_{2} \mathrm{O}$, place Line L1 into T1 (DI Water)

- Turn on pump and run for one hour. Record time on/off, flowrate and feed source.

- Place Line L1 into T3 (2.5 $\underline{\mathrm{M} \mathrm{NaOH})}$

- Turn on pump and run for one hour. Record time on/off, flowrate and feed source.

- Close and confirm closure of all valves.

The total time to condition the resin will be 3 to 4 hours.

\subsubsection{R-F Apparatus Pump Curve Acquisition}

Because of the varying pressure drops across the apparatus dependent upon sampling location, pump curves will be developed with the loaded columns while feeding $2.5 \underline{\mathrm{M}}$ $\mathrm{NaOH}$. This fluid, used in resin conditioning, is also expected to well represent the density and viscosity of waste feed. Following the pump curve acquisition, the flow settings configuration (Config. 1) may be used to ensure adequate flow at the apparatus terminus (line 
WHC-SD-RE-TPI-001, Rev. 0

A8).

Use Sheet 20 to record and conduct this procedure

- Tare receiver bottle $(\sim 250 \mathrm{~mL})$

- Place line L1 into T3. Place line A10 into tared receiver

- Set valve positions to: Config. 2

- Close Valve V10

- Open Valve V3 to Line A10

- Set pump knob flow (low 15\%)

- Turn on pump for 20 minutes, record time on.

- Turn off pump, record time off, weigh receiver.

- Reset Valve V3 to line A3.

- Place A12 into tared receiver.

- Open Valve V7 to Line A12

- Turn on pump for 20 minutes, record time on.

- Turn off pump, record time off, weigh receiver.

- Reset Valve V7 to Line A6

- Place A8 into tared receiver.

- Open Valve V10 to line A8

- Turn on pump for 20 minutes, record time on.

- Turn off pump, close all valves, record time off, weigh receiver.

Repeat this procedure, for a total of at least five point calibration, at flow settings of apprcximately $40 \%, 50 \%, 60 \%$ and $75 \%$ of pump knob range.

\subsubsection{R-F Waste Feed Preparation and Analysis}

The waste feed will be composed of a composite of drainable supernatant liquor from samples taken from Hanford Double-Shell tank 241-AW-101 during the 1996 core drilling operations which commenced in February 1996 (Benar 1996). The waste feed is of apprcximately $10 \mathrm{M} \mathrm{Na}{ }^{+}$and $5 \mathrm{M} \mathrm{OH}$. The waste feed will be diluted to a target of

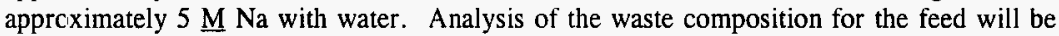
carried out by thermal ionization mass spectrometry and inductively coupled plasma at Pacif ic Northwest National Laboratory (PNNL) under separate work order.

It is anticipated that the supernatant liquor will be delivered to the $1 \mathrm{~F}$ Hot Cell in $125 \mathrm{~mL}$ bottles, any undiluted material will remain stoppered. The waste material may be delivered to the hotcell at unspecified times. No time constraint for this work applies with the exception that test run $(\$ 4.2 .6 .4)$ cannot proceed unless the material is prepared.

Use Sheet 8 to conduct and record this procedure.

- Take an aliquot of the waste material and submit it for density analysis. 
- By mass, add $350 \mathrm{~mL}$ equivalent of waste liquor from waste sample bottles (550 $\mathrm{g}$ at $\mathrm{SPG}=1.56$ ) of waste liquor into $1 \mathrm{~L}$ mixing vessel. Record source material history (core, segment, bottle) on Sheet 8.

- Add DI water to mixing vessel in aliquots to equal waste mass divided by density $(\sim 350 \mathrm{~g})$. Record actual mass added.

- Mix on magnetic stirring plate.

- Allow to settle, and decant clear liquor into feed tank T2.

- Tare centrifuge cones.

- Centrifuge the remaining liquor, and decant into feed tank T2. Record observations of liquor clarity, color and of any suspended solids.

- Upon completion of waste material addition to T2, remove an aliquot $(\sim 5 \mathrm{~mL})$ from $\mathrm{T} 2$ into prelabeled sample vial F1.

- Take an additional aliquot of the waste feed from T2 and submit it for density analysis.

- Weigh all centrifuge cones for summation of solids mass.

- Place a sample $(\sim 1 \mathrm{~g})$ of centrifuge solids in prelabeled sample vial FS1

\subsubsection{System Flush}

After the system is assembled in the hot cell, begin the test by setting pump rates and flushing the system.

Use Sheet 4 to set pump and Sheet 5 to record and conduct the system flush.

Set Pump:

Object $4 \mathrm{CV} / \mathrm{hr}=31.4 \mathrm{~mL} / \mathrm{hr}=31.4 \mathrm{~g} / \mathrm{hr}\left(\mathrm{DI} \mathrm{H}_{2} \mathrm{O}\right)=$

- Tare receiver bottle $(\sim 100 \mathrm{~mL}$ capacity $)$

- Place line L1 into T1 (DI Water)

- Place Line A10 into receiver

- Set valve positions to: Config. 1. Confirm and record valving alignment.

- Set flow rate - turn on pump, measure for 15 min. Check against objective, record results.

- Reset to get to objective as necessary, repeat.

- When at objective, confirm flow with two more test periods.

- Shut down pump

Flust System:

- Place Line A8 into tared collection vessel

- Place Line L1 into T3 (2.5 $\underline{\mathrm{M} \mathrm{NaOH})}$

- Place System Valving in Config. 2. Confirm and record valving alignment.

- Turn on pump and run for 100 minutes. Record time on/off, flowrate and feed source.

- Close and confirm closure of all valves.

The $2.5 \mathrm{M} \mathrm{NaOH}$ from the conditioning phase $(\$ 4.2 .2)$ will have been flushed through the column and testing for ${ }^{137} \mathrm{Cs}$ removal may begin. 


\subsubsection{Cesium Removal Test Run}

Although it is anticipated that breakthrough $\left({ }^{137} \mathrm{Cs} C / \mathrm{C}_{0}=0.5\right)$ will occur at 62 to $65 \mathrm{CV}$, the test run will schedule use of $80 \mathrm{CV}$ to ensure data past breakthrough will be obtained. The lest will proceed until $\mathrm{C} / \mathrm{C}_{0}=0.6-0.75$ and will be discontinued by direction of the lead engineer or chemist.

\subsubsection{Beta-Gamma Detector Data Logging}

During the test run, the beta-gamma detector will be continuously monitoring the effluent line and recording data on an IBM ${ }^{3}$ compatible computer using the GammaVision ${ }^{4}$ program. The breakthrough of ${ }^{137} \mathrm{Cs}$ will be indicated by the increase in gamma response over time for the window of $\sim 610-680 \mathrm{KeV}$. The detector logging should commence with initial feed startup ( $\$ 4.2 .6 .4)$ and discontinue with final sample acquisition from the flow stream following the test column.

\subsubsection{Primary Column Sampling}

All samples will be recorded with column number, date time/group, sample sequence number (C1E-1, C1E-2, ...C1E-n). The leading front of the treated effluent stream is anticipated at $1 \mathrm{hr} 32 \mathrm{~min}$ after pump start. Samples will be acquired for a period of 20 hours following this front passage of the sampling point.

Samples will be acquired as detailed in Table 4 .

Sampling shall be conducted using Sheet 9 for sample acquisition data and Sheet 10 for process parameters of the sample.

- Record sample number, sampling time, and beta-gamma probe response on Sheets 9 and 10 as required.

- Tare flush vial

- Tare sample vial and stopper

- Place line A12 into flush vial in base holder.

- Redirect valve V7 to allow line A12 effluent to enter vial to flush the line ( $2 \mathrm{~mL})$

- Return valve V7 to flow configuration (Config. 2)

- Remove line A12 from flush vial, move flush vial aside and place sample vial in base holder.

- Place line A.12 into sample vial.

- Redirect valve V7 to allow effluent to enter sampie vial to volume of approximately $5 \mathrm{~mL}$. Time sample acquisition time for pump calibration confirmation.

- Return valve V7 to flow configuration (Config. 2)

${ }^{3}$ IBM is a trademark of International Business Machines, Inc., White Plains, NY.

4 GammaVision is a trademark of EG\&G ORTEC, Inc., Oak Ridge, TN. 
Table 4: R-F Test Run Primary Column Sampling

\begin{tabular}{|c|c|}
\hline Sample & $\begin{array}{c}\text { Projected Run } \\
\text { Time }\end{array}$ \\
\hline C1E-1 & $1 \mathrm{hr} 32 \mathrm{~min}$ \\
\hline $\mathrm{C} 1 \mathrm{E}-2$ & $2 \mathrm{hr} 47 \mathrm{~min}$ \\
\hline C1E-3 & $4 \mathrm{hr} 2 \mathrm{~min}$ \\
\hline C1E-4 & $5 \mathrm{hr} 17 \mathrm{~min}$ \\
\hline C1E-5 & $6 \mathrm{hr} 32 \mathrm{~min}$ \\
\hline C1E-6 & $7 \mathrm{hr} 47 \mathrm{~min}$ \\
\hline C1E-7 & $9 \mathrm{hr} 2 \mathrm{~min}$ \\
\hline C1E-8 & $10 \mathrm{hr} 17 \mathrm{~min}$ \\
\hline C1E-9 & $11 \mathrm{hr} 32 \mathrm{~min}$ \\
\hline C1E-10 & $12 \mathrm{hr} 47 \mathrm{~min}$ \\
\hline C1E-11 & $14 \mathrm{hr} 2 \mathrm{~min}$ \\
\hline C1E-12 & $15 \mathrm{hr} 17 \mathrm{~min}$ \\
\hline C1E-13 & $16 \mathrm{hr} 32 \mathrm{~min}$ \\
\hline C1E-14 & $17 \mathrm{hr} 47 \mathrm{~min}$ \\
\hline C $1 E-15$ & $19 \mathrm{hr} 2 \mathrm{~min}$ \\
\hline C1E-16 & $20 \mathrm{hr} 17 \mathrm{~min}$ \\
\hline CiE-17 & $21 \mathrm{hr} 32 \mathrm{~min}$ \\
\hline
\end{tabular}

- Remove line A12 from vial and stopper sample vial.

- Close valve V7 and allow residual fluid in line A12 to fall into flush vial.

- Weigh stoppered sample vial and record.

- Move sample vial to sample retention/rack pending transfer out of cell for analysis.

- Weigh flush vial and record.

- Calculate flow rate from net sample mass and flow time. Read system flow from pump curve.

DURING THE TEST RUN, ALL SAMPLE POINTS (LINES A8, A10, A12) WILL HAVE A CATCH CONTAINER TO CONTAIN SPILLS.

\section{ALL VALVING CONFIGURATIONS REQUIRE THAT ALL VALVES NOT SPECIFIED AS OPEN SHALL BE CLOSED.}


If the system flow rate varies from the target flow by $> \pm 10 \%$, reset the pump through change procedures in $\S 5.0$. It must be recalled that system target flow rates are established as rates of effluent following the guard column. With the guard column out of the flow path during sampling, it is expected that flows from the sample point will be slightly higher than they would be with the added pressure drop across the guard column. Hence, the pump curves of Sheet 20 are required to appropriately monitor flow.

\subsubsection{Effluent Sampling}

The sampling from the guard column (C2), will be a total composite sample. At test initiation place a $2 \mathrm{~L}$ container under V10/A8. This volume should be sufficient to contain all effluent. At the end of the run, take an aliquot of approximately $5 \mathrm{~mL}$ for analysis. Identify the sample as C2E-1.

\subsubsection{Run Execution}

Use Sheet 5 to record and conduct this procedure.

Confirm or do:

Objective: $4 \mathrm{CV} / \mathrm{hr}=31.4 \mathrm{~mL} / \mathrm{hr}$

- Tare receiver bottle $(\sim 2 \mathrm{~L})$

- Place Line A8 into tared receiver

- Rinse line $\mathrm{L} 1$ at feed end with $\mathrm{H}_{2} \mathrm{O}$

- Place line L1 into T2 (Waste Feed)

- Establish valving for Config. 2. Confirm and record valving alignment on Sheet 5.

- Measure and record feed temperature $\left({ }^{\circ} \mathrm{C}\right)$

- Turn on pump and initiate test run clock. Record test initiation on Sheet 5.

- Acquire data and samples as directed above.

- Continue flow until $\beta-\gamma$ probe response is in range of $\sim 60-75 \% \mathrm{C} / \mathrm{C}_{0}$.

- Immediately following last primary column sample, shut down pump, and take the composite effluent sample from the receiver below A8.

- Close and confirm closure of all valves.

\subsubsection{System Flush}

After the feed solution has run through the system, the system will be flushed with $2.5 \underline{\mathrm{M}}$ $\mathrm{NaOH}$ for $10 \mathrm{CV}$ at $4 \mathrm{CV} / \mathrm{h}$ (2.5 hours). Allow the flush to run to a suitable container (1L).

Use Sheet 5 to record and conduct this procedure.

DURING THE TEST RUN, ALL SAMPLE POINTS (LINES A8, A10, A12) WILL HAVE A CATCH CONTAINER TO CONTAIN SPILLS.

ALL VALVING CONFIGURATIONS REQUIRE THAT ALL VALVES NOT SPECIFIED AS OPEN SHALL BE CLOSED. 
- Wash exterior of Line L1 with $\mathrm{H}_{2} \mathrm{O}$, place $\mathrm{L} 1$ in T3 (2.5 $\left.\underline{\mathrm{M}} \mathrm{NaOH}\right)$

- Tare Flush receiver.

- Place A8 into flush waste receiver (1L)

- Establish valving for Config. 2. Confirm and record valving alignment.

- Turn on pump for 2.5 hours. Record start time.

- Turn off pump. Record stop time

- Close and confirm closure of all valves.

No samples will be taken of this waste. Proceed to column elution.

\subsubsection{Column Elution}

\subsubsection{Pump Flow Set}

Use Siheet 4 to record and conduct this procedure.

Objective: $2 \mathrm{CV} / \mathrm{hr}=15.8 \mathrm{~mL} / \mathrm{hr}$

- Place line L1 into T1 (DI Water)

- Place Line A10 into graduated cylinder

- Set valve positions to: Config. 1 . Confirm and record valving alignment.

- Set flow rate - turn on pump, measure for $15 \mathrm{~min}$. Check against objective, record results.

- Reset to get to objective as necessary, repeat.

- When at objective, confirm flow with two more test periods.

- Shut down pump

- Close and confirm closure of all valves.

\subsubsection{Primary Column Elution}

After the columns ( $\mathrm{Cl}$ and $\mathrm{C} 2)$ are flushed with caustic, the columns will be eluted using $5 \mathrm{CV} \mathrm{H} \mathrm{H}_{2} \mathrm{O}$ then 10CV $0.5 \underline{\mathrm{M}} \mathrm{HNO}_{3}$.

Use Sheet(s) 6 to record and conduct this procedure.

Colurnn rinse:

- Rinse line L1 (feed end) with $\mathrm{H}_{2} \mathrm{O}$

- Place line L1 in T1

- Place line A10 into eluate receiver $(\sim 250 \mathrm{~mL})$

- Set valve positions to: Config. 3

- Turn on pump for $2^{1 / 2}$ hours. Record time on.

- Turn off pump. Record time off.

Colurnn elution:

- Place line L1 in T4

- Place line A10 into eluate receiver

- Set valve positions to: Config. 3. Confirm and record valving alignment.

- Turn on pump for 5 hours. Record time on.

- Turn off pump. Record time off. 
- Pipette two $5 \mathrm{~mL}$ aliquots of the composite eluate into sample vials labeled $\mathrm{C} 1 \mathrm{~W}-1$ and $\mathrm{C} 1 \mathrm{~W}-2$.

Follcwing this activity, prepare to conduct the elution of $\mathrm{C} 2$.

\subsubsection{Secondary Column Elution}

The discharge line will terminate in a container (eluate receiver) with a suitable volume to collert the entire eluate. No samples are to be taken from the Column $\mathrm{C} 2$ eluate.

Use Sheet(s) 7 to record and conduct this procedure.

Column rinse:

- Rinse line L1 (feed end) with $\mathrm{H}_{2} \mathrm{O}$

- Place line L1 in T1

- Place line A12 into eluate receiver ( $250 \mathrm{~mL})$

- Set valve positions to: Config. 4

- Turn on pump for $2 \frac{1 / 2}{2}$ hours. Record time on.

- Turn off pump. Record time off.

Column elution:

- Place line L1 in T4

- Place line A12 into eluate receiver

- Set valve positions to: Config. 4. Confirm and record valving alignment.

- Turn on pump for 5 hours. Record time on.

- Turn off pump. Record time off.

\subsection{CST TEST PREPARATION AND RUN}

This portion of the test plan is intended to provide explicit instructions and expectations of the conduct of ion exchange with the apparatus using crystalline silicotitanate. The expectations are that the $50 \%$ breakthrough will be at approximately 750 column volumes $\left(\lambda_{50 \%}=750 \mathrm{CV}\right)$. The run is expected to be conducted for up to 1000 column volumes, sampled every 100 column volumes for the first $500 \mathrm{CV}$ (5 samples) and every $25 \mathrm{CV}$ thereafter (20 samples).

\subsubsection{Pump Flow Set}

Objective: $10 \mathrm{CV} / \mathrm{hr}=78.5 \mathrm{~mL} / \mathrm{hr}$

Place line L1 into T1 (DI Water)

- Place Line A10 into graduated cylinder

- Set valve positions to: Config. 5. Confirm and record valving alignment.

- Set flow rate - turn on pump, measure for $15 \mathrm{~min}$. Check against objective, record results.

- Reset to get to objective as necessary, repeat.

- When at objective, confirm flow with two more test periods. 
- Shut down pump

- Close and confirm closure of all valves.

\subsubsection{Exchange Column Preparation}

Both the test column, $\mathrm{C} 3$, and the guard column, $\mathrm{C} 4$, will be charged with CST resin and cond tioned outside of the hot cell. After conditioning and pump calibration, the columns and system will be transferred into the hot cell (NOTE: SIMILAR SERIAL WORK IS REQUIRED FOR THE R-F SUBASSEMBLY PRIOR TO HOT CELL PLACEMENT). To prepare the CST resin, manufacturer's specifications will be met with fines removal and sodium hydroxide conditioning. These specifications are not incorporated herein as they are business confidential instructions, but are provided to test personnel.

Use Sheet 25 to prepare and measure the bed density of the resin.

Following this conditioning and the following pump calibration, and that of 4.2 .2 , the test assembly will be prepared for hot cell placement.

\subsubsection{CST Apparatus Pump Curve Acquisition}

Because of the varying pressure drops across the apparatus dependent upon sampling location, pump curves will be developed with the loaded columns while feeding $2.5 \underline{\mathrm{M}}$ $\mathrm{NaOH}$. This fluid, used in resin conditioning, is also expected to well represent the density and viscosity of waste feed. Following the pump curve acquisition, the flow settings configuration (Config. 5) may be used to ensure adequate flow at the apparatus terminus (line B8).

Use Sheet 21 to record and conduct this procedure

- Tare receiver bottle $(\sim 250 \mathrm{~mL})$

- Place line L1 into T3. Place line B10 into tared receiver

- Set valve positions to: Config. 6

- Close Valve V20

- Open Valve V13 to Line B10

- Set pump knob flow (low - 15\%)

- Turn on pump for 20 minutes, record time on.

- Turn off pump, record time off, weigh receiver.

- Reset -Valve V13 to line B3.

- Place B12 into tared receiver.

- Open Valve V17 to Line B12

- Turn on pump for 20 minutes, record time on.

- Turn off pump, record time off, weigh receiver.

- Reset Valve V17 to Line B6

- Place B8 into tared receiver. 
WHC-SD-RE-TPI-001, Rev. 0

- Open Valve V10 to line A8

- Turn on pump for 20 minutes, record time on.

- Turn off pump, close all valves, record time off, weigh receiver.

Repeat this procedure, for a total of at least five point calibration, at flow settings of approximately $40 \%, 50 \%, 60 \%$ and $75 \%$ of pump knob range.

\subsubsection{CST Waste Feed Preparation and Analysis}

The waste feed will be composed of a composite of drainable supernatant liquor from samples taken from Hanford Double-Shell tank 241-AW-101 during the 1996 core drilling operations which commenced in February 1996 (Benar 1996). The waste feed is of approximately $10 \underline{\mathrm{M} \mathrm{Na}}{ }^{+}$and $5 \underline{\mathrm{M} \mathrm{OH}}$. The waste feed will be diluted to a target of approximately $5 \underline{\mathrm{M}} \mathrm{Na}$ with water. Analysis of the waste composition for the feed will be carried out by thermal ionization mass spectrometry and inductively coupled plasma at PNNL laboratories under separate work order.

It is anticipated that the supernatant liquor will be delivered to the $1 \mathrm{~F}$ Hot Cell in $125 \mathrm{~mL}$ bottles, any undiluted material will remain stoppered. The waste material may be delivered to the hotcell at unspecified times. No time constraint for this work applies with the exception that test run $(\$ 4.3 .6 .4)$ cannot proceed unless the material is prepared.

This feed stock will be prepared batchwise and will initially require one or two batches, with additional batches to follow as the test proceeds. A total of approximately eight batches will be prepared in this manner.

Use Sheet(s) 15 to record and conduct this procedure.

For each batch:

- By mass, add $500 \mathrm{~mL}$ equivalent of waste liquor from waste sample bottles (780 $\mathrm{g}$ at $\mathrm{SPG}=1.56$ ) into $2 \mathrm{~L}$ mixing vessel. Density is acquired in procedure $\S 4.2 .4$.

Record source material history (core, segment, bottle) on Sheet 15.

- Add DI water to mixing vessel in aliquots to equal waste mass divided by density $(\sim 500 \mathrm{~g})$. Record actual mass added.

- Mix on magnetic stirring plate.

- Allow to settle, and decant clear liquor into feed tank T2.

- Tare centrifuge cones

- Centrifuge the remaining liquor, and decant into feed tank T2. Record observations of liquor clarity, color and of any suspended solids.

- Upon completion of waste material addition to $\mathrm{T} 2$, remove an aliquot $(-5 \mathrm{~mL})$ from T2 into prelabeled sample vial F2 (F3..F8 for additional batches).

- Record time of each new transfer into T2.

- Weigh all centrifuge cones for summation of solids mass.

To minimize waste with sequential batches continue use of centrifuge cones through no more than $1 / 3$ height of cone. 
- Composite centrifuge solids in $250-500 \mathrm{~mL}$ vial when cones exceed $1 / 3$ fill height.

- Following last batch of feed preparation take two composite samples of centrifuged solids $(\sim 1 \mathrm{~g})$ and place them in sample vials FS2 and FS3.

\subsubsection{System Flush}

After the system is assembled in the hot cell, begin the test by setting pump rates and flushing the system.

Use Sheet 11 to set pump and Sheet 12 to record and conduct the system flush.

Set P'ump:

Objective: $6 \mathrm{CV} / \mathrm{hr}=47.1 \mathrm{~mL} / \mathrm{hr}$

- Tare receiver bottle $(\sim 100 \mathrm{~mL}$ capacity $)$

- Place line L1 into T1 (DI Water)

- Place Line A10 into tared receiver

- Set valve positions to: Config. 5. Confirm and record valving alignment.

- Set flow rate - turn on pump, measure for $15 \mathrm{~min}$. Check against objective, record results.

- Reset to get to objective as necessary, repeat.

- When at objective, confirm flow with two more test periods.

- Shut down pump

Flush:

- Place Line B8 into tared receiver

- Place Line L1 into T3 (2.5 $\underline{\mathrm{M}} \mathrm{NaOH})$

- Place System Valving in Config. 6. Confirm and record valving alignment.

- Turn on pump and run for 100 minutes. Record time on/off, flowrate and feed source.

- Close and confirm closure of all valves.

The $2.5 \underline{\mathrm{M} \mathrm{NaOH}}$ from the conditioning phase $(\S 4.3 .2)$ will have been flushed through the column and testing for ${ }^{137} \mathrm{Cs}$ removal may begin.

\subsubsection{Cesium Removal Test Run}

Although it is anticipated that breakthrough $\left({ }^{137} \mathrm{Cs} C / \mathrm{C}_{0}=0.5\right)$ will occur at 750 to $800 \mathrm{CV}$, the test run will schedule use of $1000 \mathrm{CV}$ to ensure data past breakthrough will be obtained. The test will proceed until $\mathrm{C} / \mathrm{C}_{0}=0.6-0.75$ and will be discontinued by direction of the lead engineer or chemist. 


\title{
4.3.6.1 Beta-Gamma Detector Data Logging
}

During the test run, the beta-gamma detector will be continuously monitoring the effluent line and recording data on an IBM compatible computer using the GammaVision program. The breakthrough of ${ }^{137} \mathrm{Cs}$ will be indicated by the increase in gamma response over time for the window of $\sim 610-680 \mathrm{KeV}$. The detector logging should commence with initial feed startup (§ 4.3.6.4) and discontinue with final sample acquisition from the flow stream following the test column.

The beta-gamma probe must provide an additional function for this component of the test. If the response from the beta-gamma probe indicates $\mathrm{C} / \mathrm{C}_{0}<0.10$ prior to $500 \mathrm{CV}$, the sample regirne will accelerate to one sample per $25 \mathrm{CV}$.

\subsubsection{Primary Column Sampling}

All samples will be recorded with column number, date time/group, sample sequence number (C3E-1, C3E-2, ...C3E-n).

It is anticipated that the CST resin will be exposed to $1000 \mathrm{CV}$ before the test is stopped. Samples of $5 \mathrm{~mL}$ each will be taken at Valve 17. At $1000 \mathrm{CV}$ with a flow rate of $6 \mathrm{CV} / \mathrm{h}$, the test will run for 166 hours. The first sample will be taken at $1 \mathrm{hr} 30 \mathrm{~min}$, representing the effluent stream front. Additional samples will be taken every 16 hours and 40 minutes $(100 \mathrm{CV})$ through $500 \mathrm{CV}$. Subsequent samples will be taken every 4 hours and 10 minutes (25 CV) through the remainder of the test. Expected samples total 27 and are detailed on Table 5. Should the on-line beta gamma detector indicate that the cesium $\mathrm{C} / \mathrm{C}_{0}$ exceeds $10 \%$, the sample regime shall immediately (nearest $25 \mathrm{CV}$ increment) switch to the accelerated sampling structure of Table 5 . Change procedures of $\S 5.0$ will be implemented to generate new sampling runtimes in the event of accelerated sampling needs.

Samples shall be acquired as detailed in Table 5 .

Sampling shall be conducted using Sheet 16 for sample acquisition data and Sheet 17 for process parameters of the sample.

- Record sample number, sampling time, and beta-gamma probe response on Sheets 16 and 17 as required.

- Tare flush vial

- Tare sample vial and stopper

- Place line B12 into flush vial in base holder.

DURING THE TEST RUN, ALL SAMPLE POINTS (LINES B8, B10, B12) WILL HAVE A CATCH CONTAINER TO CONTAIN SPILLS.

\author{
ALL VALVING CONFIGURATIONS REQUIRE THAT ALL VALVES \\ NOT SPECIFIED AS OPEN SHALL BE CLOSED
}


WHC-SD-RE-TPI-001, Rev. 0

Table 5: CST Test Run Primary Column Sampling

\begin{tabular}{||l|l|}
\hline Sample & Projected Run Time \\
\hline C3E-1 & $1 \mathrm{hr} 30 \mathrm{~min}$ \\
\hline C3E-2 & $68 \mathrm{hr} 10 \mathrm{~min}$ \\
\hline C3E-3 & $72 \mathrm{hr} 20 \mathrm{~min}$ \\
\hline C3E-4 & $76 \mathrm{hr} 30 \mathrm{~min}$ \\
\hline C3E-5 & $80 \mathrm{hr} 40 \mathrm{~min}$ \\
\hline C3E-6 & $84 \mathrm{hr} 50 \mathrm{~min}$ \\
\hline C3E-7 & $89 \mathrm{hr} 0 \mathrm{~min}$ \\
\hline C3E-8 & $93 \mathrm{hr} 10 \mathrm{~min}$ \\
\hline C3E-9 & $97 \mathrm{hr} 20 \mathrm{~min}$ \\
\hline C3E-10 & $101 \mathrm{hr} 30 \mathrm{~min}$ \\
\hline C3E-11 & $105 \mathrm{hr} 40 \mathrm{~min}$ \\
\hline C3E-12 & $109 \mathrm{hr} 50 \mathrm{~min}$ \\
\hline C3E-13 & $114 \mathrm{hr} 0 \mathrm{~min}$ \\
\hline C3E-14 & $118 \mathrm{hr} 10 \mathrm{~min}$ \\
\hline C3E-15 & $122 \mathrm{hr} 20 \mathrm{~min}$ \\
\hline C3E-16 & $126 \mathrm{hr} 30 \mathrm{~min}$ \\
\hline C3E-17 & $130 \mathrm{hr} 40 \mathrm{~min}$ \\
\hline C3E-18 & $134 \mathrm{hr} 50 \mathrm{~min}$ \\
\hline C3E-19 & $139 \mathrm{hr} 0 \mathrm{~min}$ \\
\hline C3E-20 & $143 \mathrm{hr} 10 \mathrm{~min}$ \\
\hline C3E-21 & $147 \mathrm{hr} 20 \mathrm{~min}$ \\
\hline C3E-22 & $151 \mathrm{hr} 30 \mathrm{~min}$ \\
\hline C3E-23 & $155 \mathrm{hr} 40 \mathrm{~min}$ \\
\hline C3E-24 & $159 \mathrm{hr} 50 \mathrm{~min}$ \\
\hline C3E-25 & $164 \mathrm{hr} 0 \mathrm{~min}$ \\
\hline C3E-26 & $168 \mathrm{hr} 10 \mathrm{~min}$ \\
\hline C3E-27 & $172 \mathrm{hr} 20 \mathrm{~min}$ \\
\hline
\end{tabular}

- Place line B12 into flush vial in base holder.

- Redirect valve V17 to allow line B12 effluent to enter vial to flush the line ( $2 \mathrm{~mL}$ )

- Return valve V17 to flow configuration (Config. 6)

- Remove line B12 from flush vial, move flush vial aside and place sample vial in base

DURING THE TEST RUN, ALL SAMPLE POINTS (LINES B8, B10, B12)

WILL HAVE A CATCH CONTAINER TO CONTAIN SPILLS.

ALL VALVING CONFIGURATIONS REQUIRE THAT ALL VALVES NOT SPECIFIED AS OPEN SHALL BE CLOSED 
WHC-SD-RE-TPI-001, Rev. 0 .

holder.

- Place line B12 into sample vial.

- Redirect valve V17 to allow effluent to enter sample vial to volume of approximately $5 \mathrm{~mL}$. Time sample acquisition time for pump calibration confirmation.

- Return valve V17 to flow configuration (Config. 6)

- Remove line B12 from vial and stopper sample vial.

- Close valve V17 and allow residual fluid in line A12 to fall into flush vial.

- Weigh stoppered sample vial and record.

- Move sample vial to sample retention/rack pending transfer out of cell for analysis.

- Weigh flush vial and record.

- Calculate flow rate from net sample mass and flow time. Read system flow from pump curve.

If the system flow rate varies from the target flow by $> \pm 10 \%$, reset the pump through change procedures in $\S 5.0$. It must be recalled that system target flow rates are established as rates of effluent following the guard column. With the guard column out of the flow path during sampling, it is expected that flows from the sample point will be slightly higher than they would be with the added pressure drop across the guard column. Hence, the pump curves of Sheet 21 are required to appropriately monitor flow.

\subsubsection{Effluent Sampling}

The sampling from the guard column (C4), will be a total composite sample. At test initiation place a $2 \mathrm{~L}$ container under V20/B8. This volume should be sufficient for approximately 40 hours of operation. Replace this container when it has reached $75 \%$ of capacity or will do so by the next sampling effort. At the end of the run, take an aliquot of approximately $5 \mathrm{~mL}$ from each container. Identify the samples as $\mathrm{C} 4 \mathrm{E}-1$ to $\mathrm{C} 4 \mathrm{E}-\mathrm{n}$, where $\mathrm{n}$ is the container number (should not exceed 6).

\subsubsection{Run Execution}

Use Sheet 12 to record and conduct this procedure

Confirm or do:

Objective: $6 \mathrm{CV} / \mathrm{hr}=47.1 \mathrm{~mL} / \mathrm{hr}$

- Tare receiver bottle $(\sim 2 \mathrm{~L})$

- Rinse line $\mathrm{L} 1$ at feed end with $\mathrm{H}_{2} \mathrm{O}$

- Place Line B8 into $2 \mathrm{~L}$ collection vessel

- Place line L1 into T2 (Waste Feed)

- Confirm valving for Config. 6. Confirm and record valving alignment on Sheet 12.

DURING THE TEST RUN, ALL SAMPLE POINTS (LINES B8, B10, B12) WILL HAVE A CATCH CONTAINER TO CONTAIN SPILLS.

\section{ALL VALVING CONFIGURATIONS REQUIRE THAT ALL VALVES NOT SPECIFIED AS OPEN SHALL BE CLOSED}


- Measure and record feed temperature $\left({ }^{\circ} \mathrm{C}\right)$

- Turn on pump and initiate test run clock. Record test initiation on Sheet 12.

- Acquire data and samples as directed above.

- Continue flow until $\beta-\gamma$ probe response is in range of $\sim 60-75 \% \mathrm{C} / \mathrm{C}_{0}$.

- Immediately following last sample primary column sample, shut down pump, and take the composite effluent sample from the received below B8.

- Close and confirm closure of all valves.

\subsubsection{System Flush}

After the feed solution has run through the system at $1000 \mathrm{CV}$, the system will be flushed with $2.5 \mathrm{M} \mathrm{NaOH}$ for $10 \mathrm{CV}$ at $6 \mathrm{CV} / \mathrm{h}$ (1.66 hours). Allow the flush to run to a suitable conta.iner (1L).

Use Sheet 12 to record and conduct this procedure.

- Wash exterior of Line L1 with $\mathrm{H}_{2} \mathrm{O}$, place $\mathrm{L} 1$ in T3 (2.5 $\left.\underline{\mathrm{M}} \mathrm{NaOH}\right)$

- Place B8 into flush waste receiver (1L)

- Establish valving for Config. 6. Confirm and record valving alignment.

- Turn on pump for 2.5 hours. Record start time.

- Turn off pump. Record stop time

- Close and confirm closure of all valves.

No samples will be taken of this waste. Proceed to column elution.

\subsubsection{Column Elution}

This material will not be eluted under present planning. If elution becomes necessary, eluticin procedures similar to those above will be herein amended.

\subsection{SYSTEM CLEANOUT AND WASTE MANAGEMENT}

This section is applicable to both R-F and CST resin columns. The application of this section is to minimize the volume and form of waste to be disposed from the hot cells. Wasties shall be handled in accordance with WAC 173-303 (Ecology 1994).

DURING THE TEST RUN, ALL SAMPLE POINTS (LINES B8, B10, B12) WILL HAVE A CATCH CONTAINER TO CONTAIN SPILLS.

ALL VALVING CONFIGURATIONS REQUIRE THAT ALL VALVES NOT SPECIFIED AS OPEN SHALL BE CLOSED 


\subsubsection{Thermolabile Wastes}

All poly tubing, thermoplastics, etc. that will melt are to be placed in a metal container. The container will then be placed on a hot plate and the material melted in accordance with appropriate procedure (LO-100-106, Marshall 1994), the can cooled and sealed and disposed in accordance with WAC 173-303. (WDOE 1994)

\subsubsection{Resin Columns}

Use Sheet 22 for R-F resin dissolution and Sheet 23 for CST dissolution record and procedural conduct.

Prior to removing the columns, confirm the following valve positions:

$\begin{array}{lll}\text { C1 } & \text { V5 } & \text { off } \\ \text { C2 } & \text { V9 } & \text { off } \\ \text { C3 } & \text { V15 } & \text { off } \\ \text { C4 } & \text { V19 } & \text { off }\end{array}$

These valves are the lower isolation valves for the columns. When removing the columns, the ttbing should be crimped to inhibit leaks. The material in the columns should, be removed from the columns by removing the top of the column and rinsing and scraping the resin into a receiver.

From the determination of the amount of acid $\left(\mathrm{HNO}_{3}\right.$ for $\mathrm{R}-\mathrm{F}$ and $\mathrm{HCl}$ and $\mathrm{HF}$ for $\mathrm{CST}$ ) under section 4.1 .4 , remove the resin from $\mathrm{C} 1$, and digest proportionately, sampling as SRF2, SRF3, and SRF4. Digest C2 in the same manner, no samples are to be taken. Each column should be dissolved separately. Remove the resin from $\mathrm{C} 3$ and digest proportionately to Sheet 19 observations, sampling as SCST2, SCST3, and SCST4. Digest C4 in the same manner, no samples are to be taken. Each column should be dissolved separately. The samples will be analyzed by AEA, ICP and GEA.

NOTE: Due to the proprietary nature of the CST resin substrate and binder, analytical infonmation from sample analyses of this material will not be publicly released.

Remaining dissolved exchange material solutions are to be poured down the hot cell drain.

\subsubsection{Other Liquors}

Effluent materials from test conduct, acquired at A8 and B8, are to be retained, in separate, labeled, 1 liter bottles. These materials will be shipped to PNNL for additional anionic exchange studies.

Waste flushes and washes are to be poured down the hot cell drain. Unanalyzed samples, unles: otherwise specified at test close out, are to be poured down the hot cell drain. Unused diluted waste feed, unless otherwise specified at test close out, are to be poured 
dowil the hot cell drain. Unused and undiluted waste feed is to be returned to archive.

\subsubsection{Other Solid Wastes}

Other solid wastes will include the glass exchange columns, valves, fittings, and glassware for rnaterial handling. This material should be triple rinsed and packaged for disposal. Pour rinse liquors down hot cell drain.

\subsection{SAMPLING AND SAMPLE ANALYSES}

Analytical sample selection for analyses of feed wastes, effluents, digest, and eluates are presented in Table 6. Rubidium, potassium, strontium, and cesium isotopic analyses are to be conducted by thermal ionization mass spectroscopy (TIMS); hydroxide by potentiometric titration or specific ion electrode, other metals $(\mathrm{Na}, \mathrm{Al}, \mathrm{K}, \mathrm{Cr}, \mathrm{Fe}, \mathrm{P})$ are to by analyzed by inductively coupled plasma atomic emission spectroscopy (ICP-AES), transuranic metals (Am, Pu, Np) are to be analyzed by alpha emission spectroscopy, and ${ }^{137} \mathrm{Cs}$ and ${ }^{134} \mathrm{Cs}$ by gamina energy analysis (GEA). Selected waste feeds and effluents will be analyzed for total organic carbon by TOC, total inorganic carbon, and for nitrate, nitrite, fluoride, chloride, and sulfate by ion chromatography. Test conduct will include on-line beta-gamma analysis.

\begin{tabular}{|c|c|c|c|c|c|c|c|c|c|c|c|}
\hline & Method & \multirow[t]{2}{*}{ TIMS } & \multirow{2}{*}{$\begin{array}{l}\text { ICP- } \\
\text { AES }\end{array}$} & \multirow[t]{2}{*}{ GEA } & \multirow[t]{2}{*}{ AEA } & \multirow[t]{2}{*}{ IC } & \multirow[t]{2}{*}{ TIC } & \multirow[t]{2}{*}{ TOC } & \multirow[t]{2}{*}{$\overline{\mathrm{OH}}-$} & \multirow[t]{2}{*}{ Density } & \multirow{2}{*}{$\begin{array}{c}\text { On-line } \\
\beta-\gamma\end{array}$} \\
\hline Sample & Description & & & & & & & & & & \\
\hline \multicolumn{12}{|l|}{ Core } \\
\hline \multicolumn{12}{|c|}{ R-F Cesiunn Ion Exchange Test } \\
\hline SRF1 & cold RF digest & & $\bar{X}$ & & & & & & & & \\
\hline SRF2 & hot RF digest & & $\bar{X}$ & $\mathrm{X}$ & $\mathrm{X}$ & & & & & & \\
\hline SRF3 & hot RF digest & & $\mathrm{X}$ & $\mathrm{X}$ & $\bar{X}$ & & & & & & \\
\hline SRF4 & hot RF digest & & $\mathrm{X}$ & $\mathrm{X}$ & $\mathrm{X}$ & & & & & & \\
\hline W1D & Raw Waste & & & & & & & & & $\mathrm{X}$ & \\
\hline FID & Waste Feed & & & & & & & & & $\mathrm{X}$ & \\
\hline F1 & Waste Feed & & $\mathrm{X}$ & $\mathrm{X}$ & $\mathrm{X}$ & $\mathrm{X}$ & $\mathrm{X}$ & $\mathrm{X}$ & $\mathrm{X}$ & & \\
\hline FS1 & Centrifuge slds & & $\mathrm{X}$ & $\mathrm{X}$ & $\mathrm{X}$ & & & & & & \\
\hline C1E-1 & C1 Eftluent & & $\mathrm{X}$ & $\mathrm{X}$ & & & & & & & $\mathrm{X}$ \\
\hline CIE-2 & C1 Eftluent & & $\mathrm{X}$ & $\mathrm{X}$ & & & & & & & $\bar{x}$ \\
\hline $\mathrm{C} 1 \mathrm{E}-3$ & C1 Effluent & & $\mathrm{X}$ & $\mathrm{X}$ & & $x$ & $\bar{X}$ & & $\mathrm{X}$ & & $\bar{X}$ \\
\hline C1E-4 & C1 Eftluent & & $\mathrm{X}$ & $\bar{X}$ & & & & & & & $\bar{X}$ \\
\hline $\mathrm{ClE}-5$ & C1 Eftluent & & $\mathrm{X}$ & $\mathrm{X}$ & & & & & & & $\mathrm{X}$ \\
\hline C1E-6 & C1 Eftluent & & $\mathrm{X}$ & $\mathrm{X}$ & & & & & & & $\mathrm{X}$ \\
\hline C1E-7 & C1 Eftluent & & $\mathrm{X}$ & $\mathrm{X}$ & & $x$ & $\mathrm{X}$ & & $\mathrm{X}$ & & $\bar{x}$ \\
\hline CIE-8 & $\mathrm{Cl}$ Effluent & & $\mathrm{X}$ & $x$ & & & & & & & $\mathrm{X}$ \\
\hline C1E-9 & Cl Eftluent & & $\mathrm{X}$ & $\mathrm{x}$ & & & & & & & $x$ \\
\hline C1E-10 & C1 Eftluent & & $\mathrm{X}$ & $\mathrm{X}$ & & & & & & & $\mathrm{X}$ \\
\hline C1E-11 & C1 Effluent & & $\mathrm{X}$ & $\mathrm{X}$ & & $\mathrm{X}$ & $\mathrm{X}$ & & $\mathrm{X}$ & & $\mathrm{X}$ \\
\hline C1E-12 & C1 Eftluent & & $x$ & $x$ & & & & & & & $\mathrm{x}$ \\
\hline
\end{tabular}


WHC-SD-RE-TPI-001, Rev. 0

\begin{tabular}{|c|c|c|c|c|c|c|c|c|c|c|c|}
\hline & Method & TIMS & ICP- & GEA & AEA & IC & TIC & TOC & OH- & Density & On-line \\
\hline Sample & Description & & & & & & & & & & \\
\hline C1E-13 & C1 Effluent & & $\mathrm{X}$ & $\mathrm{x}$ & & & & & & & $\mathrm{X}$ \\
\hline C1E-14 & C1 Effluent & & $\mathbf{X}$ & $\bar{X}$ & & & & & & & $\mathrm{X}$ \\
\hline C1E-15 & C1 Effluent & & $\bar{x}$ & $\mathrm{X}$ & & $\mathrm{X}$ & $\mathrm{X}$ & & $\bar{X}$ & & $\mathrm{X}$ \\
\hline C1E-16 & C1 Effluent & & $\mathrm{x}$ & $\mathrm{X}$ & & & & & & & $\mathrm{X}$ \\
\hline C1E-17 & C1 Effluent & & $\mathrm{x}$ & $\mathrm{X}$ & & & & & & & $\mathrm{x}$ \\
\hline $\mathrm{C} 2 \mathrm{E}-1$ & Comp. C2 Effluent & $\mathrm{X}$ & $\mathrm{X}$ & $X$ & & $\mathrm{X}$ & $\mathrm{X}$ & $\bar{X}$ & & & \\
\hline C1W-1 & Comp. C1 Eluate & & $\mathrm{X}$ & $\mathrm{X}$ & $\bar{x}$ & & & & & & \\
\hline $\mathrm{C} 1 \mathrm{~W}-2$ & Comp. C1 Eluate & & $\bar{X}$ & $\mathrm{X}$ & $\mathbf{X}$ & & & & & & \\
\hline \multicolumn{12}{|c|}{ CST Cesium Ion Exchange Test } \\
\hline SCST1 & cold CST digest & & $\mathrm{x}$ & & & & & & & & \\
\hline SCST2 & hot CST digest & & $\bar{X}$ & $\mathrm{X}$ & $\bar{X}$ & & & & & & \\
\hline SCST3 & hot CST digest & & $\mathrm{X}$ & $\mathrm{X}$ & $\mathrm{X}$ & & & & & & \\
\hline SCST4 & hot CST digest & & $\mathrm{X}$ & $\mathrm{X}$ & $\mathrm{x}$ & & & & & & \\
\hline $\bar{F} 2$ & Waste Feed & & $\mathrm{X}$ & $\mathrm{x}$ & $\mathrm{X}$ & $\mathrm{X}$ & $\mathrm{x}$ & & $x$ & & \\
\hline $\mathrm{F}^{3}$ & Waste Feed & & $\mathrm{X}$ & $\mathrm{X}$ & $\mathrm{x}$ & $\mathrm{X}$ & $\mathrm{x}$ & $\bar{x}$ & $\mathrm{X}$ & & \\
\hline$\overline{F 4}$ & Waste Feed & & $\mathrm{X}$ & $\bar{X}$ & $\mathrm{X}$ & $\mathrm{X}$ & $\mathrm{X}$ & & $\mathrm{X}$ & & \\
\hline F5 & Waste Feed & & $\mathrm{X}$ & $\mathrm{X}$ & $\mathrm{X}$ & $\mathrm{X}$ & $\mathrm{X}$ & & $\overline{\mathrm{X}}$ & & \\
\hline F6 & Waste Feed & & $\mathrm{x}$ & $\mathrm{x}$ & $\mathrm{X}$ & $\mathrm{X}$ & $\mathrm{X}$ & $\mathrm{X}$ & $\mathrm{X}$ & & \\
\hline F7 & Waste Feed & & $\mathrm{X}$ & $x$ & $\mathrm{X}$ & $\mathrm{X}$ & $\bar{X}$ & & $\mathrm{X}$ & & \\
\hline F8 & Waste Feed & & $\mathrm{X}$ & $\mathrm{X}$ & $x$ & $\mathrm{X}$ & $\mathrm{X}$ & & $\mathrm{X}$ & & \\
\hline F9 & Waste Feed & & $\bar{x}$ & $\mathrm{X}$ & $\mathrm{X}$ & $\mathrm{X}$ & $\mathrm{X}$ & $\mathrm{X}$ & $\mathrm{X}$ & & \\
\hline FS2 & Centrifuge slds & & $\mathrm{X}$ & $\mathrm{X}$ & $\mathrm{X}$ & & & & & & \\
\hline FS3 & Centrifuge slds & & $\mathrm{X}$ & $\mathrm{X}$ & $\mathrm{X}$ & & & & & & \\
\hline C3E-1 & C3 Effluent & & $\mathrm{X}$ & $\mathrm{x}$ & & & & & & & $\mathrm{X}$ \\
\hline $\mathrm{C} 3 \mathrm{E}-2$ & C3 Effluent & & $\mathrm{X}$ & $\bar{x}$ & & & & & & & $\mathrm{X}$ \\
\hline $\mathrm{C} 3 \mathrm{E}-3$ & C3 Effluent & & $\mathrm{X}$ & $\mathrm{X}$ & & $\mathrm{x}$ & $\mathrm{X}$ & & $\mathrm{X}$ & & $x$ \\
\hline C3E-4 & C3 Effluent & & $\mathrm{X}$ & $\mathrm{X}$ & & & & & & & $x$ \\
\hline C3E-5 & C3 Effluent & & $\mathrm{X}$ & $\mathrm{X}$ & & & & & & & $\mathrm{x}$ \\
\hline C3E-6 & C3 Effluent & & $\mathrm{X}$ & $\mathrm{X}$ & & & & & & & $\mathrm{X}$ \\
\hline C3E-7 & C3 Effluent & & $\mathrm{X}$ & $\mathrm{X}$ & & $\mathrm{X}$ & $\mathrm{X}$ & & $x$ & & $x$ \\
\hline C3E-8 & C3 Effluent & & $\mathrm{X}$ & $\mathrm{X}$ & & & & & & & $\mathrm{X}$ \\
\hline C3E-9 & C3 Eftluent & & $\mathrm{X}$ & $\mathrm{X}$ & & & & & & & $x$ \\
\hline C3E-10 & C3 Effluent & & $\mathrm{X}$ & $\mathrm{X}$ & & & & & & & $\mathrm{X}$ \\
\hline C3E-11 & C3 Eftluent & & $\mathrm{X}$ & $\mathrm{X}$ & & $\mathrm{x}$ & $\mathrm{x}$ & & $\mathrm{X}$ & & $x$ \\
\hline C3E-12 & C3 Effluent & & $x$ & $X$ & & & & & & & $\mathrm{X}$ \\
\hline C3E-13 & C3 Effluent & & $\mathrm{X}$ & $X$ & & & & & & & $\mathrm{X}$ \\
\hline C3E-14 & C3 Effluent & & $\mathrm{X}$ & $X$ & & & & & & & $x$ \\
\hline C3E-15 & C3 Effluent & & $\mathrm{x}$ & $x$ & & $\mathrm{X}$ & $\mathrm{X}$ & & $\bar{x}$ & & $\mathrm{X}$ \\
\hline C3E-16 & C3 Effluent & & $X$ & $x$ & & & & & & & $\mathrm{X}$ \\
\hline C3E-17 & C3 Effluent & & $\mathrm{X}$ & $\mathrm{X}$ & & & & & & & $\mathrm{X}$ \\
\hline C3E-18 & C3 Effluent & & $\bar{x}$ & $\bar{x}$ & & & & & & & $x$ \\
\hline
\end{tabular}


WHC-SD-RE-TPI-001, Rev. 0

\begin{tabular}{|c|c|c|c|c|c|c|c|c|c|c|c|}
\hline & Method & \multirow[t]{2}{*}{ TIMS } & \multirow{2}{*}{$\begin{array}{l}\text { ICP- } \\
\text { AES }\end{array}$} & \multirow[t]{2}{*}{ GEA } & \multirow[t]{2}{*}{ AEA } & \multirow[t]{2}{*}{ IC } & \multirow[t]{2}{*}{ TIC } & \multirow[t]{2}{*}{ TOC } & \multirow[t]{2}{*}{ OH- } & \multirow[t]{2}{*}{ Density } & \multirow{2}{*}{$\underset{\beta-\gamma}{\text { On-line }}$} \\
\hline Sample & Description & & & & & & & & & & \\
\hline C3E-19 & C3 Effluent & & $\mathrm{X}$ & $\mathrm{x}$ & & $\mathrm{X}$ & $\mathrm{X}$ & & $\mathrm{X}$ & & $\mathrm{X}$ \\
\hline C3E-20 & C3 Effluent & & $\bar{X}$ & $\mathrm{X}$ & & & & & & & $\bar{x}$ \\
\hline $\mathrm{C} 3 \mathrm{E}-21$ & C3 Effluent & & $\mathrm{x}$ & $\mathrm{X}$ & & & & & & & $\bar{x}$ \\
\hline C3E-22 & C3 Effluent & & $\mathrm{X}$ & $\mathrm{X}$ & & & & & & & $\mathrm{X}$ \\
\hline C3E-23 & C3 Effluent & & $\mathrm{X}$ & $\mathrm{x}$ & & $\mathrm{X}$ & $\mathrm{X}$ & & $\mathrm{X}$ & & $\bar{x}$ \\
\hline C3E-24 & C3 Effluent & & $\mathrm{X}$ & $\bar{x}$ & & & & & & & $\bar{X}$ \\
\hline C3E-25 & C3 Effluent & & $\bar{x}$ & $\bar{x}$ & & & & & & & $\mathrm{X}$ \\
\hline C3E-26 & C3 Effluent & & $\bar{x}$ & $\mathrm{X}$ & & & & & & & $\bar{x}$ \\
\hline C3E-27 & C3 Effluent & & $\mathrm{X}$ & $\mathrm{X}$ & & $x$ & $\mathrm{X}$ & & $\mathrm{X}$ & & $\bar{x}$ \\
\hline C4E-1 & Comp. C4 Effluent & $\bar{X}$ & $\mathrm{X}$ & $\mathrm{X}$ & & $\mathrm{X}$ & $\mathrm{X}$ & $\bar{x}$ & & $\bar{x}$ & \\
\hline $\mathrm{C} 4 \mathrm{E}-2$ & Comp. C4 Effluent & & $\bar{x}$ & $\bar{x}$ & $X$ & & & & $x$ & & \\
\hline C4E-3 & Comp. C4 Effluent & $\mathrm{X}$ & $\bar{x}$ & $\bar{x}$ & & $\mathrm{X}$ & $\mathrm{X}$ & $\bar{x}$ & & $\bar{X}$ & \\
\hline C4E-4 & Comp. C4 Effluent & & $\bar{x}$ & $\bar{x}$ & $\mathrm{X}$ & & & & $\mathrm{X}$ & & \\
\hline C4E-5 & Comp. C4 Effluent & $\bar{X}$ & $\bar{X}$ & $\mathrm{x}$ & & $\mathrm{X}$ & $\mathrm{X}$ & $\bar{X}$ & & $\mathrm{X}$ & \\
\hline $\mathrm{C} 4 \mathrm{E}-6$ & Comp. C4 Effluent & & $\mathrm{X}$ & $\mathrm{X}$ & $\bar{x}$ & & & & $\bar{X}$ & & \\
\hline \multicolumn{2}{|c|}{ Total Samples/Method } & TIMS & $\begin{array}{l}\text { ICP- } \\
\text { AES }\end{array}$ & GEA & AEA & IC & TIC & TOC & OH- & Density & $\begin{array}{c}\text { On-line } \\
\beta-\gamma\end{array}$ \\
\hline 76 & & 5 & 74 & 72 & 24 & 25 & 25 & 9 & 24 & 6 & 45 \\
\hline
\end{tabular}

NOTE: Due to the proprietary nature of the resin substrate and binder, analytical infonmation from sample analyses of this material (SCST1, SCST2, SCST3, SCST4) will not be publicly released.

\subsection{CHANGE PROCEDURE}

\subsection{General Changes}

As in any experimental test conduct, the possibility of procedural change revision requirement exists. Should procedural change be mandated to ensure adequate performance of the work and safe conduct of operations, the operating personnel may institute the required change with approval of the lead engineer or chemist. Such change will be incorporated in an engineering change notice at test completion for appropriate configuration control.

\subsection{Sampling Frequency Change}

Due to the potential of early breakthrough of analytes of interest (i.e. ${ }^{137} \mathrm{Cs}$ ) in test columns, the on-line $\beta-\gamma$ detector will be operated to report effluent activities. Should the activity exceed $10 \%$ of breakthrough prior to sampling frequency shift stated in sampling sections of 
4.2.6.4 and 4.3.6.4, then the operating personnel should contact the lead engineer or chemist and institute a sampling frequency shift as directed. That shift must be defined in terms of run time (i.e. flow volume). Such change will be incorporated in an engineering change notice at test completion for appropriate configuration control.

\subsection{Pump Flow Rate Reset}

Due to the potential of pump flow rate drift through tubing crimping, exchange material degradation, or other causes, the test apparatus flow may depart from the test objective rate. Should the observed rate under 4.2.6.4 and 4.3.6.4, deviate from the object by greater than $10 \%$, the pump rate should be reset to the appropriate rate through procedures on Sheets 20 and 21 for R-F and CST respectively. The operating personnel may institute the required change with approval of the lead engineer or chemist. Such change will be incorporated in an engineering change notice at test completion for appropriate configuration control.

\subsection{QUALITY ASSURANCE}

Quality assurance requirements are guided by 10 CFR 830.120 Quality Assurance Requirements (DOE 1994a) and by the Implementation Guide for Use with 10 CFR 830.120 (DOE: 1994b). The implementation of 10 CFR 830.120 is through the Quality Assurance Manual (WHC 1996) and facility specific quality assurance plans.

Existent quality assurance requirements encompassed by the Quality Assurance Plan (Meznarich 1995) of the laboratory facilities will be met in the conduct of this work and its chemical analysis. The quality assurance for the conduct of the unit operation and hot cell activities will be in accordance with the approved process testing quality assurance plan (Meznarich 1996).

\subsection{REFERENCES.}

Beck, M. A., R. S. Addleman, G. R. Blewitt, E. R. Selle, C. S. McClellan, D. A. Dodd, G. L. Troyer, and B. D. Keele, 1996, Remote Nuclear Screening System for Hostile Environments, WHC-SD-WM-DTR-024, Rev. 0, Westinghouse Hanford Company, Richland, Washington, February 27, 1996.

Benar, C. J., 1996, Tank 241-AW-10I Push Mode Core Sampling and Analysis Plan, WHC-SD-WM-TSAP-024, Rev. 0, Westinghouse Hanford Company, Richland, Washington, January $15,1996$.

DOE. 1994a, Nuclear Safety Management, "Quality Assurance Requirements," 10 CFR 830.120, U. S. Department of Energy, Washington D.C., April 5, 1994.

DOE 1994b, Implementation Guide for Use with 10 CFR 830.120 Quality Assurance, G-830.120-Rev. 0, U. S. Department of Energy, Washington D.C., April 15, 1994. 
EPA, 1986, 40 CFR \$261.31, Hazardous wastes from non-specific sources, U. S. Environmental Protection Agency, Washington, D.C., August 25, 1986.

Hendrickson, D. W., and J. B. Duncan, Hanford Tank Waste Supernatant Cesium Removal Test Plan, WHC-SD-RE-TP-022, Rev. 0, Westinghouse Hanford Company, Richland, Washington, May 1996.

Marshall, R. P., 1994, Melting Plastic Material in Cubicles of the 222-S Laboratory, LO-100-106, Westinghouse Hanford Company, Richland, Washington, March 1994.

Meznarich, H. K., 1995, 222-S Laboratory Quality Assurance Plan, WHC-SD-CP-QAPP-016, Rev. 0, Westinghouse Hanford Company, Richland, Washington, July 31, 1995.

Meznarich, H. K., 1996, 222-S Process and Development Laboratory Quality Assurance Plan, WHC-SD-CP-QAPP-018, Rev. 0, Westinghouse Hanford Company, Richland, Washington, June 1996.

Perry, R. H., D. W. Green, J. O. Maloney, Perry's Chemical Engineer's Handbook, Sixth Edition, McGraw-Hill Book Company, New York, New York, 1984.

WDCE, 1994, Washington Administrative Code, Chapter 173-303, Dangerous Waste Regulations, (WAC 173-303), Washington Department of Ecology, Olympia, Washington, January 8, 1994. 
WHC-SD-RE-TPI-001, Rev. 0

THIS PAGE INTENTIONALLY LEFT BLANK 
WHC-SD-RE-TPI-001, Rev. 0

Appendix A: Checksheets and Data Sheets 
WHC-SD-RE-TPI-001, Rev. 0

THIS PAGE INTENTIONALLY LEFT BLANK 


\section{LIST OF CHECKSHEETS AND DATASHEETS}

SHEET

PAGE

1: Feed System Assembly . . . . . . . . . . . . . . . . . A-1

2: R-F Test Assembly Instructions and Checksheet ........... A-2

3: CST Test Assembly Instructions and Checksheet . . . . . . . . . . . . A-3

4: Config. 1: R-F Pump Flow Rate Valving and Calibration ...... A-4

5: Config. 2: R-F Subassembly Forward Feed Valving Configuration . . A A-5

6: Config. 3: R-F Subassembly Column 1 Reverse Feed Valving . . . . . . A-6

7: Config. 4: R-F Subassembly Column 2 Reverse Feed Valving . . . . . . A-7

8: R-F Waste Feed Preparation . . . . . . . . . . . . . . . . . A-8

9: R-F Test Run Primary Column Sampling ............. A-9

10: R-F Test Run Primary Column Sample Record . . . . . . . . . . . . . . A-10

11: Config. 5: CST Pump Flow Rate Valving and Calibration . . . . . . . A-11

12: Config. 6: CST Subassembly Forward Feed Valving Configuration . . . A-12

13: Config. 7: CST Subassembly Column 3 Reverse Feed Valving . . . . . . A-13

14: Config. 8: CST Subassembly Column 4 Reverse Feed Valving . . . . A-14

15: CST Waste Feed Preparation . . . . . . . . . . . . . . . . A-15

16: CST Test Run Primary Column Sampling . . . . . . . . . . . . . . . A-16

17: CST Test Run Primary Column Sample Record . . . . . . . . . . . . A-17

18: R-F Resin Dissolution . . . . . . . . . . . . . . . . . . A-18

19: CST Resin Dissolution . . . . . . . . . . . . . . A-19

20: Pump Calibration for the R-F Resin Column Test . . . . . . . . . . A-20

21: Pump Calibration for the CST Resin Column Test . . . . . . . . A-22

22: R-F Resin Dissolution............... . A-24

23: CST Resin Dissolution................ . A-25

24: R-F Resin Bed Density Determination . . . . . . . . . . . A-26

25: CST Resin Bed Density Determination . . . . . . . . . . A-27 
WHC-SD-RE-TPI-001, Rev. 0

THIS PAGE INTENTIONALLY LEFT BLANK

A-iv 
Sheet 1: Feed System Assembly

See Figure $A-3$ and Figure $A-4$ :

Assemble Line Ll as composite of $1.5 \mathrm{~m}$ Tygon tubing, $0.89 \mathrm{~mm}$ ID, fitted to $10 \mathrm{~cm}$ Tygon tubing, $3.175 \mathrm{~mm}$ ID

Connect $3.175 \mathrm{~mm}$ ID end of LI to Valve VI

Mount $0.89 \mathrm{~mm}$ ID segment of LI through pump head

Assembly confirmed:

Date:

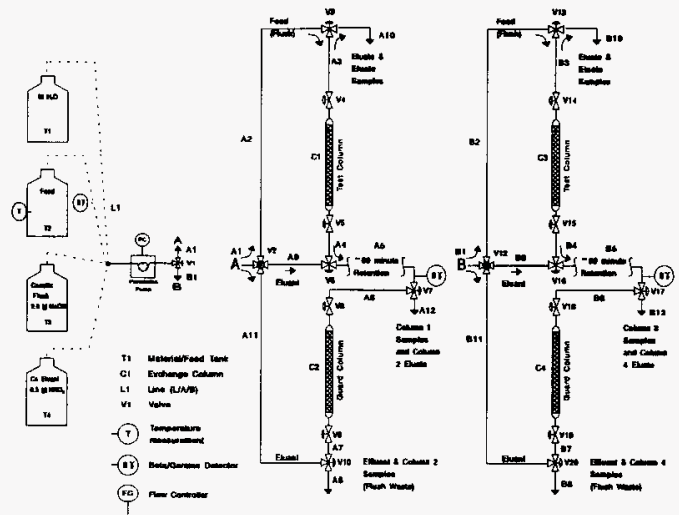

Figure A-3: Bench-Scale Cesium Exchange Flows and Instrumentation

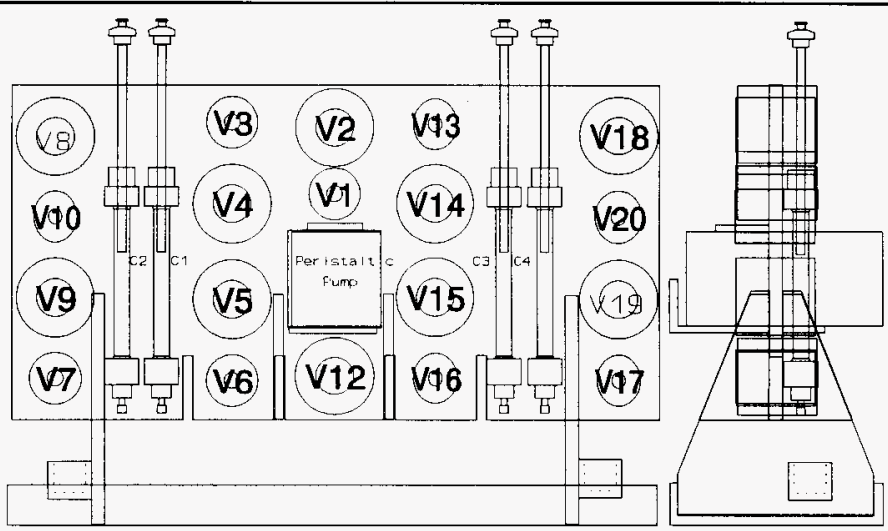

Figure A-4: Physical Test Assembly Valve and Column Arrangement 
Sheet 2: R-F Test Assembly Instructions and Checksheet

Mount valves and columns in test assembly (See Figure A-3 for flow intent, Figure A-4 for layout).

Connect line A1 $\left(3.2 \mathrm{~mm}\right.$ ID, $11 \mathrm{~cm}$ Tygon $\left.^{5}\right)$ to $\mathrm{V} 1$ and $\mathrm{V} 2$.

Connect 1 ine A2 $(3.2 \mathrm{~mm} \mathrm{ID,} 7 \mathrm{~cm}$ Tygon) to V2 and V3.

Connect line $A 3(3.2 \mathrm{~mm} \mathrm{ID}, 11 \mathrm{~cm}$ Tygon) to $\mathrm{V} 3$ and $\mathrm{V} 4$.

Connect line (Composite, $3.2 \mathrm{~mm}$ ID, $10 \mathrm{~cm}$ Tygon to $0.5 \mathrm{~mm} \mathrm{ID,} 32 \mathrm{~cm}$ Teflon) to $\mathrm{V} 4$ and $\mathrm{Cl}$ (top).

Connect line (Composite, $0.5 \mathrm{~mm} \mathrm{ID,} 19 \mathrm{~cm}$ Teflon to $3.2 \mathrm{~cm}, 4 \mathrm{~cm}$ Tygon) to $\mathrm{Cl}$ (bottom) and V5.

Connect line A4 $(3.2 \mathrm{~mm} \mathrm{ID}, 25 \mathrm{~cm}$ Tygon) to $\mathrm{V} 5$ and $V 6$.

Connect line A5 (V6 to composite: $3.2 \mathrm{~mm}$ ID, $3 \mathrm{~cm}$ Tygon joined to

$5 \mathrm{~mm}$ ID, $191 \mathrm{~cm}$ Tygon joined to $3.2 \mathrm{~mm}$ ID, $32 \mathrm{~cm}$ Tygon to $V 7$ )

Connect line A6 ( $3.2 \mathrm{~mm} \mathrm{ID,} 27 \mathrm{~cm}$ Tygon) to $\mathrm{V} 7$ and $\mathrm{V} 8$.

Connect line (Composie, $0.5 \mathrm{~mm}$ ID, $45 \mathrm{~cm}$ Teflon to $3.2 \mathrm{~mm}$ ID, $3 \mathrm{~cm}$ Tygon) to V8 and C2 (top).

Connect line (Composite, $0.5 \mathrm{~mm}$ ID, $29 \mathrm{~cm}$ Teflon to $3.2 \mathrm{~mm} \mathrm{ID,} 3 \mathrm{~cm}$ Tygon) to C2 (bottom) and $\mathrm{V} 9$.

Connect line A7 (3.2 $\mathrm{mm}$ ID, $8 \mathrm{~cm}$ Tygon) to $\mathrm{V} 9$ and $\mathrm{V} 10$.

Connect line A8 $(3.2 \mathrm{~mm}$ ID, $48 \mathrm{~cm}$ Tygon) to VIO.

Connect 1 ine $A 9(3.2 \mathrm{~mm} \mathrm{ID,} 41 \mathrm{~cm}$ Tygon) to $\mathrm{V} 2$ and $\mathrm{V} 6$.

Connect 1 ine $A 10(3.2 \mathrm{~mm} \mathrm{ID,} 58 \mathrm{~cm}$ Tygon) to $\mathrm{V} 3$.

Connect line All $(3.2 \mathrm{~mm} \mathrm{ID,} 37 \mathrm{~cm}$ Tygon) to $\mathrm{V} 2$ and $\mathrm{V} 10$.

Connect line Al2 $(3.2 \mathrm{~mm}$ ID, $21 \mathrm{~cm}$ Tygon) to $V 7$.

init.

Assembly confirmed:

Date:

5 Tygon is a trademark of Norton Performance Plastics, Akron, $\mathrm{OH}$. 
Sheet 3: CST Test Assembly Instructions and Checksheet

Mount valves and columns in test assembly (See Figure A-3 for flow intent, Figure A-4 for 1 1ayout).

Connect line $B 1(3.2 \mathrm{~mm} I D, 32 \mathrm{~cm}$ Tygon) to $\mathrm{Vl}$ and $\mathrm{V} 12$.

Connect line B2 $(3.2 \mathrm{~mm}$ ID, $45 \mathrm{~cm}$ Tygon) to $\mathrm{V} 12$ and $\mathrm{V} 13$.

Connect line B3 $(3.2 \mathrm{~mm} \mathrm{ID,} 12 \mathrm{~cm}$ Tygon) to V13 and V14.

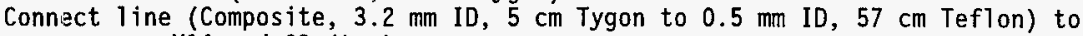
V14 and C3 (top).

Connect line (Composite, $0.5 \mathrm{~mm}$ ID, $25 \mathrm{~cm}$ Teflon to $3.2 \mathrm{~mm}$ ID, $4 \mathrm{~cm}$ Tygon) to C3 (bottom) and V15.

Connect line B4 (3.2 mm ID, $21 \mathrm{~cm}$ Tygon) to V15 and V16.

Connect line B5 (V16 to composite: $3.2 \mathrm{~mm}$ ID, $4 \mathrm{~cm}$ Tygon joined to

$4.8 \mathrm{~mm} \mathrm{ID,} 290 \mathrm{~cm}$ Tygon to $3.2 \mathrm{~mm} \mathrm{ID,} 4 \mathrm{~cm}$ Tygon to

V17)

Connect 1 ine B6 $(3.2 \mathrm{~mm}$ ID, $27 \mathrm{~cm}$ Tygon) to V17 and V18.

Connect line (Composite, $3.2 \mathrm{~mm}$ ID, $2 \mathrm{~cm}$ Tygon to $0.5 \mathrm{~mm}$ ID, $54 \mathrm{~cm}$ Teflon) to V18 and C4 (top).

Connect line (Composite, $0.5 \mathrm{~mm}$ ID, $59 \mathrm{~cm}$ Teflon to $3.2 \mathrm{~mm} \mathrm{ID,} 3 \mathrm{~cm}$ Tygon) to C4 (bottom) and V19.

Connect 7 ine B7 ( $3.2 \mathrm{~mm} \mathrm{ID,} 9 \mathrm{~cm}$ Tygon) to V19 and V20.

Connect line B8 $(3.2 \mathrm{~mm}$ ID, $48 \mathrm{~cm}$ Tygon) to $\mathrm{V} 20$.

Connect line B9 $(3.2 \mathrm{~mm} \mathrm{ID,} 16 \mathrm{~cm}$ Tygon) to $\mathrm{V} 12$ and $\mathrm{V} 16$.

Connect line B10 $(3.2 \mathrm{~mm} \mathrm{ID,} 58 \mathrm{~cm}$ Tygon) to $\mathrm{V} 13$.

Connect 1 ine B11 (3.2 mm ID, $51 \mathrm{~cm}$ Tygon) to V12 and V2O.

Connect line B12 $(3.2 \mathrm{~mm}$ ID, $21 \mathrm{~cm}$ Tygon) to V17.

init

Assembly confirmed:

Date: 
WHC-SD-RE-TPI-001, Rev. 0

Sheet 4: Config. 1: R-F Pump Flow Rate Valving and Calibration Configuration Checksheet and Datasheet

Executed for Test Procedure Step: Checksheet\#

Executed by:

Date/time:

Target Flow Rate: $\mathrm{g} / \mathrm{hr}$

Receiver/bottle tare: grams

Feed Line (L1) into Feed Tank:

Feed Material: Density $\mathrm{g} / \mathrm{mL}$

Effluent Line (A10) into receiver

Valve Placement/Confirmation (See Figure A-3) other valves closed:

\begin{tabular}{||l|l|l|}
\hline Valve & Position & Direction \\
\hline V1 & Open & $\mathrm{L} 1 \rightarrow \mathrm{V} 1 \rightarrow \mathrm{A} 1$ \\
\hline V2 & Open & $\mathrm{A} 1 \rightarrow \mathrm{V} 2 \rightarrow \mathrm{A} 2$ \\
\hline V3 & Open & $\mathrm{A} 2 \rightarrow \mathrm{V} 3 \rightarrow \mathrm{A} 10$ \\
\hline
\end{tabular}

\begin{tabular}{|c|c|c|c|c|c|c|c|c|c|}
\hline \multirow{2}{*}{$\underset{(m \cdot n)}{\text { Time }}$} & \multicolumn{3}{|c|}{ Mass (g) } & \multirow{2}{*}{$\begin{array}{c}\text { Flow } \\
(\mathrm{g} / \mathrm{hr})\end{array}$} & \multirow{2}{*}{$\begin{array}{c}\text { Time } \\
(\min )\end{array}$} & \multicolumn{3}{|c|}{ Mass (g) } & \multirow{2}{*}{$\begin{array}{l}\text { Flow } \\
(\mathrm{g} / \mathrm{hr})\end{array}$} \\
\hline & Tare & Gross & Net & & & Tare & Gross & Net & \\
\hline & & & & & & & & & \\
\hline & & & & & & & & & \\
\hline & & & & & & & & & \\
\hline & & & & & & & & & \\
\hline & & & & & & & & & \\
\hline & & & & & & & & & \\
\hline
\end{tabular}

Flow Rate $=$ Average of last three test periods without pump setting change

Flow Rate $=$ $\mathrm{g} / \mathrm{hr}=$ $\mathrm{mL} / \mathrm{hr}$ 
WHC-SD-RE-TPI-001, Rev. 0

Sheet 5: Config. 2: R-F Subassembly Forward Feed Valving Configuration Configuration Checksheet and Datasheet

Executed for Test Procedure Step: Checksheet\#

Executed by:

Date/time:

Receiver/bottle tare: grams

Feed Line (L1) into Feed Tank:

Feed Material: Density__ $\mathrm{g} / \mathrm{mL}$

Effluent Line (A8) into

Valve Placement/Confirmation (See Figure A-3) other valves closed:

\begin{tabular}{|l|l|l|}
\hline Valve & Position & Direction \\
\hline $\mathrm{V} 1$ & Open & $\mathrm{LI} \rightarrow \mathrm{V} 1 \rightarrow \mathrm{Al}$ \\
\hline $\mathrm{V} 2$ & Open & $\mathrm{A} 1 \rightarrow \mathrm{V} 2 \rightarrow \mathrm{A} 2$ \\
\hline $\mathrm{V} 3$ & Open & $\mathrm{A} 2 \rightarrow \mathrm{V} 3 \rightarrow \mathrm{A} 3$ \\
\hline $\mathrm{V} 4$ & Open & $\mathrm{A} 3 \rightarrow \mathrm{V} 4 \rightarrow \mathrm{C} 1$ \\
\hline $\mathrm{V} 5$ & Open & $\mathrm{C} 1 \rightarrow \mathrm{V} 5 \rightarrow \mathrm{A} 4$ \\
\hline V6 & Open & $\mathrm{A} 4 \rightarrow \mathrm{V} 6 \rightarrow \mathrm{A} 5$ \\
\hline V7 & Open & $\mathrm{A} 5 \rightarrow \mathrm{V} 7 \rightarrow \mathrm{A} 6$ \\
\hline V8 & Open & $\mathrm{A} 6 \rightarrow \mathrm{V} 8 \rightarrow \mathrm{C} 2$ \\
\hline V9 & Open & $\mathrm{C} 2 \rightarrow \mathrm{V} 9 \rightarrow \mathrm{A} 7$ \\
\hline V10 & Open & $\mathrm{A} 7 \rightarrow \mathrm{V} 10 \rightarrow \mathrm{A} 8$ \\
\hline
\end{tabular}

Flow Rate (from Sheet 4, Checksheet:\# ) : $\mathrm{mL} / \mathrm{hr}$

Pump 0n: Observations: (time/date)

Pump 0ff: (time/date)

Mass Collected (gross receiver): (Use additional sheets for mass collection if collection vessel changed) $g$ (net collected): 9 
WHC-SD-RE-TPI-001, Rev. 0

Sheet 6: Config. 3: R-F Subassembly Column 1 Reverse Feed Valving

Configuration Checksheet and Datasheet

Executed for Test Procedure Step: Checksheet\#

Executed by:

Date/time:

Receiver/bottle tare: grams

Feed Line (L1) into Feed Tank:

Feed Materia7:

Density $\mathrm{g} / \mathrm{mL}$

Effluent Line (Al0) into

Valve $\mathrm{P} 1$ acement/Confirmation (See Figure A-3) other valves closed:

\begin{tabular}{|l|l|l|}
\hline VaTve & Position & Direction \\
\hline $\mathrm{V} 1$ & Open & $\mathrm{L} 1+\mathrm{V} 1 \rightarrow \mathrm{A} 1$ \\
\hline $\mathrm{V} 2$ & Open & $\mathrm{A} 1+\mathrm{V} 2 \rightarrow \mathrm{A} 9$ \\
\hline $\mathrm{V} 6$ & Open & $\mathrm{A} 9 \rightarrow \mathrm{V} 6 \rightarrow \mathrm{A} 4$ \\
\hline $\mathrm{V} 5$ & Open & $\mathrm{A} 4+\mathrm{V} 5 \rightarrow \mathrm{C} 1$ \\
\hline $\mathrm{V} 4$ & Open & $\mathrm{C} 1 \rightarrow \mathrm{V} 4 \rightarrow \mathrm{A} 3$ \\
\hline $\mathrm{V} 3$ & Open & $\mathrm{A} 3 \rightarrow \mathrm{V} 3 \rightarrow \mathrm{A} 10$ \\
\hline
\end{tabular}

Flow Rate (from Sheet 4, Checksheet\#___): $\mathrm{mL} / \mathrm{hr}$

Pump 0n: (time/date)

observations:

Pump 0ff: (time/date)

Mass Collected (gross receiver): (Use additional sheets for mass collection if collection vessel changed)

g (net collected): 9 
WHC-SD-RE-TPI-001, Rev. 0

Sheet 7: Config. 4: R-F Subassembly Column 2 Reverse Feed Valving Configuration Checksheet and Datasheet

Executed for Test Procedure Step: Checksheet\#

Executed by:

Date/time:

Receiver/bottle tare: grams

Feed Line (LI) into Feed Tank:

Feed Material:

Density $\mathrm{g} / \mathrm{mL}$

Effluent Line (A12) into

Valve $\mathrm{Placement} /$ Confirmation (See Figure $\mathrm{A}-3$ ) other valves closed:

\begin{tabular}{|l|l|l|}
\hline Valve & Position & Direction \\
\hline $\mathrm{V} 1$ & Open & $\mathrm{L} 1 \rightarrow \mathrm{V} 1 \rightarrow \mathrm{Al}$ \\
\hline $\mathrm{V} 2$ & Open & $\mathrm{A} 1 \rightarrow \mathrm{V} 2 \rightarrow \mathrm{A} 11$ \\
\hline $\mathrm{V} 10$ & Open & $\mathrm{A} 11 \rightarrow \mathrm{V} 10 \rightarrow \mathrm{A} 7$ \\
\hline $\mathrm{V} 9$ & Open & $\mathrm{A} 7 \rightarrow \mathrm{V} 9 \rightarrow \mathrm{C} 2$ \\
\hline $\mathrm{V} 8$ & Open & $\mathrm{C} 2 \rightarrow \mathrm{V} 8 \rightarrow \mathrm{A} 6$ \\
\hline $\mathrm{V} 7$ & Open & $\mathrm{A} 6 \rightarrow \mathrm{V} 7 \rightarrow \mathrm{A} 12$ \\
\hline
\end{tabular}

Flow Rate (from Sheet 4, Checksheet\#__ ): _ $\mathrm{mL} / \mathrm{hr}$

Pump 0n: (time/date)

Observations:

Pump 0ff: (time/date)

Mass Collected (gross receiver): (Use auditional sheets for mass collection if collection vessel changed) 
WHC-SD-RE-TPI-001, Rev. 0

\section{Sheet 8: R-F Waste Feed Preparation}

Checksheet and Data Sheet

Objective: Prepare $700 \mathrm{~mL}$ of waste feed for $\mathrm{R}-\mathrm{F}$ resin test.

Executed for Test Procedure Step: 4 4.2.4 Checksheet\#

Executed by:

Date/time:

Waste: Core / Riser / Segment \#'s:

Take an aliquot of the waste for density analysis in a prelabeled vial W1D.

Density Analysis of Waste: $\mathrm{g} / \mathrm{mL}$

1. By mass, add $350 \mathrm{~mL}$ equivalent of waste liquor from waste sample bottles (550 $\mathrm{g}$ at $\mathrm{SPG}=1.56$ ) of waste 1 iquor into $1 \mathrm{~L}$ mixing vessel. Actual mass added / density $\mathrm{g} / \mathrm{mL})=$ $\mathrm{mL}$.

2. Add DI water to mixing vessel in aliquots to equal waste mass divided by density. Actual volume added

3. Mix on magnetic stirring plate until no crystals are visible.

4. Allow to settle, decant clear liquor into feed tank T2.

5. Tare centrifuge cones.

6. Centrifuge the waste material mixture, and decant into feed tank T2. Observations of liquor clarity, color and of any suspended solids:

7. Upon completion of waste material addition to feed tank T2, pipette a $5 \mathrm{~mL}$ al iqout into prelabeled sample vial $\mathrm{Fl}$.

8. Take an additional aliquot from T2 and submit it for density analysis, into a prelabeled sample vial F1D.

9. Place any centrifuge solids in prelabeled sample vial FSl.

10. Weigh all centrifuge cones to determine the accumulated mass.

11. Place 1 gram of the centrifuge solids in a prelabeled sample vial FS1. 
WHC-SD-RE-TPI-001, Rev. 0

Sheet 9: R-F Test Run Primary Column Sampling

Configuration Checksheet and Datasheet

Executed for Test Procedure Step:

Checksheet\#

Executed by:

Completed Date/time:

Feed Line (LI) into Feed Tank:

Feed Material:

Sample Vial plus stopper Tare weight: g

Flush Vial Tare g

Effluent Line (A12) into Flush Vial

Valve Placement/Confirmation: (See Figure A-3) Configuration 2

Change V7 position:

from: $A 5+V 7+A 6$

to: $\mathrm{A} 5 \rightarrow \mathrm{V} 7 \rightarrow \mathrm{Al} 2$

Flow Rate (from Sheet 4, Checksheet\#___): $\mathrm{g} / \mathrm{hr}$

Collect $-2 \mathrm{~mL}$ in Flush vial

Place 1 ine Al2 into sample vial

Collect $5 \mathrm{~mL}$ in sample vial;

Time of collection: $\min$ $\sec$

Redirect valve $V 7$ back to $l$ ine $A 6$

Change $V 7$ position:

from: $\mathrm{A} 5 \rightarrow \mathrm{V} 7 \rightarrow \mathrm{Al} 2$

to: $\quad A 5 \rightarrow V 7 \rightarrow A 6$

Weight flush: g Net flush: g

Weight Sample + stopper: g, Net Sample: g

Flow rate $=$ Net Sample / sample time $=$ $\mathrm{g} / \mathrm{hr}$ $\mathrm{g} / \mathrm{hr} /$ density $=$ $\mathrm{mL} / \mathrm{hr}$

Observations: 
WHC-SD-RE-TPI-001, Rev. 0

Sheet 10: R-F Test Run Primary Column Sample Record

Sample Datasheet

Executed for Test Procedure Step:

Checksheet\#

Executed by:

Completed Date/time:

Run Start (Date/time):

\begin{tabular}{|c|c|c|c|c|c|}
\hline Sample & $\begin{array}{l}\text { Projected } \\
\text { Run Time } \\
\end{array}$ & $\begin{array}{l}\text { Projected } \\
\text { clock Time }\end{array}$ & $\begin{array}{c}\text { Actual } \\
\text { clock Time }\end{array}$ & On-Line $\beta-y$ & $\begin{array}{c}\text { Feed Temp. } \\
\left({ }^{\circ} \mathrm{C}\right)\end{array}$ \\
\hline C1E-1 & $1 \mathrm{hr} 32 \mathrm{~min}$ & & & & \\
\hline$C 1 E-2$ & $2 \mathrm{hr} 47 \mathrm{~min}$ & & & & \\
\hline C1E-3 & $4 \mathrm{hr} 2 \mathrm{~min}$ & & & & \\
\hline C1E-4 & $5 \mathrm{hr} 17 \mathrm{~min}$ & & & & \\
\hline$C 1 E-5$ & $6 \mathrm{hr} 32 \mathrm{~min}$ & & & & \\
\hline$C 1 E-6$ & $7 \mathrm{hr} 47 \mathrm{~min}$ & & & & \\
\hline C1E-7 & $9 \mathrm{hr} 2 \mathrm{~min}$ & & & & \\
\hline CIE-8 & $10 \mathrm{hr} 17 \mathrm{~min}$ & & & & \\
\hline C tE-9 & $11 \mathrm{hr} 32 \mathrm{~min}$ & & & & \\
\hline CIE- 10 & 12 hr 47 min & & & & \\
\hline CtE-11 & $14 \mathrm{hr} 2 \mathrm{~min}$ & & & & \\
\hline C1E-12 & $15 \mathrm{hr} 17 \mathrm{~min}$ & & & & \\
\hline C1E- 13 & $16 \mathrm{hr} 32 \mathrm{~min}$ & & & & \\
\hline C1E- 14 & $17 \mathrm{hr} 47 \mathrm{~min}$ & & & & \\
\hline C1E-15 & $19 \mathrm{hr} 2 \mathrm{~min}$ & & & & \\
\hline C1E- 16 & $20 \mathrm{hr} 17 \mathrm{~min}$ & & & & \\
\hline C1E-17 & 21 hr 32 min & & & & \\
\hline
\end{tabular}


WHC-SD-RE-TPI-001, Rev, 0

Sheet 11: Config. 5: CST Pump Flow Rate Valving and Calibration Configuration Checksheet and Datasheet

Executed for Test Procedure Step: Checksheet\#

Executed by:

Date/time:

Target Flow Rate: $g / h r$

Receiver/bottle tare: grams

Feed Line (LI) into Feed Tank:

Feed Materia1:

Density $\mathrm{g} / \mathrm{mL}$

Effluent Line (A10) into receiver

Valve $\mathrm{Placement/Confirmation} \mathrm{(See} \mathrm{Figure} \mathrm{A}-3$ ) other valves closed:

\begin{tabular}{||l|l|l|}
\hline Valve & Position & Direction \\
\hline $\mathrm{V} 11$ & Open & $\mathrm{L} 1 \rightarrow \mathrm{V} 11+\mathrm{B} 1$ \\
\hline $\mathrm{V} 12$ & Open & $\mathrm{B} 1 \rightarrow \mathrm{V} 12 \rightarrow \mathrm{B} 2$ \\
\hline $\mathrm{V} 13$ & Open & $\mathrm{B} 12 \rightarrow \mathrm{V} 13 \rightarrow \mathrm{B} 10$ \\
\hline
\end{tabular}

\begin{tabular}{|c|c|c|c|c|c|c|c|c|c|}
\hline \multirow{2}{*}{$\begin{array}{c}\text { Time } \\
(\mathrm{min})\end{array}$} & \multicolumn{3}{|c|}{ Mass $(g)$} & \multirow{2}{*}{$\begin{array}{c}\text { Flow } \\
(\mathrm{g} / \mathrm{hr})\end{array}$} & \multirow{2}{*}{$\begin{array}{l}\text { Time } \\
\text { (min) }\end{array}$} & \multicolumn{3}{|c|}{ Mass (g) } & \multirow{2}{*}{$\begin{array}{c}\text { Flow } \\
(\mathrm{g} / \mathrm{hr})\end{array}$} \\
\hline & Tare & Gross & Net & & & Tare & Gross & Net & \\
\hline & & & & & & & & & \\
\hline & & & & & & & & & \\
\hline & & & & & & & & & \\
\hline & & & & & & & & & \\
\hline & & & & & & & & & \\
\hline & & & & & & & & & \\
\hline
\end{tabular}

Flow Rate $=$ Average of last three test periods without pump setting change

Flow Rate $=$ $\mathrm{g} / \mathrm{hr} /$ density $=$ $\mathrm{mL} / \mathrm{hr}$ 
Sheet 12: Config. 6: CST Subassembly Forward Feed Valving Configuration Configuration Checksheet and Datasheet

Executed for Test Procedure Step: Checksheet\#

Executed by:

Date/time:

Receiver/bottle tare: grams

Feed Line (L1) into Feed Tank:

Feed Material:

Density $\mathrm{g} / \mathrm{mL}$

Effluent Line (B8) into

Valve $\mathrm{Placement/Confirmation} \mathrm{(See} \mathrm{Figure} \mathrm{A}-3$ ) other valves closed:

\begin{tabular}{|l|l|l|}
\hline Valve & Position & Direction \\
\hline $\mathrm{V} 1$ & Open & $\mathrm{L} 1 \rightarrow \mathrm{V} 1 \rightarrow \mathrm{B} 1$ \\
\hline $\mathrm{V} 12$ & Open & $\mathrm{B} 1 \rightarrow \mathrm{V} 12 \rightarrow \mathrm{B} 2$ \\
\hline $\mathrm{V} 13$ & Open & $\mathrm{B} 2 \rightarrow \mathrm{V} 13 \rightarrow \mathrm{B} 3$ \\
\hline $\mathrm{V} 14$ & Open & $\mathrm{B} 3 \rightarrow \mathrm{V} 14 \rightarrow \mathrm{C} 3$ \\
\hline $\mathrm{V} 15$ & Open & $\mathrm{C} 3 \rightarrow \mathrm{V} 15 \rightarrow \mathrm{B} 4$ \\
\hline $\mathrm{V} 16$ & Open & $\mathrm{B} 4 \rightarrow \mathrm{V} 16+\mathrm{B} 5$ \\
\hline $\mathrm{V} 17$ & Open & $\mathrm{B} 5 \rightarrow \mathrm{V} 17 \rightarrow \mathrm{B} 6$ \\
\hline $\mathrm{V} 18$ & Open & $\mathrm{B} 6 \rightarrow \mathrm{V} 18+\mathrm{C} 4$ \\
\hline $\mathrm{V} 19$ & Open & $\mathrm{C} 4 \rightarrow \mathrm{V} 19 \rightarrow \mathrm{B} 7$ \\
\hline $\mathrm{V} 20$ & Open & $\mathrm{B} 7 \rightarrow \mathrm{V} 20+\mathrm{B} 8$ \\
\hline
\end{tabular}

Flow Rate (from Sheet 11 Checksheet\#__ ): _ $\mathrm{mL} / \mathrm{hr}$

Pump On:

Observations: (time/date)

Pump 0ff: (time/date)

Mass Collected (gross receiver): (Use additional sheets for mass collection if collection vessel changed) 
WHC-SD-RE-TPI-001, Rev. 0

Sheet 13: Config. 7: CST Subassembly Column 3 Reverse Feed Valving Configuration Checksheet and Datasheet

Executed for Test Procedure Step: Checksheet\#

Executed by:

Date/time:

Receiver/bottle tare: grams

Feed Line (L1) into Feed Tank:

Feed Material: Density $\mathrm{g} / \mathrm{mL}$

Effluent Line $(B 10)$ into

Valve $\mathrm{Placement/Confirmation} \mathrm{(See} \mathrm{Figure} \mathrm{A}-3$ ) other valves closed:

\begin{tabular}{|l|l|l|}
\hline Valve & Position & Direction \\
\hline $\mathrm{V} 1$ & Open & $\mathrm{L} 1 \rightarrow \mathrm{V} 1 \rightarrow \mathrm{B} 1$ \\
\hline $\mathrm{V} 12$ & Open & $\mathrm{B} 1 \rightarrow \mathrm{V} 12 \rightarrow \mathrm{B} 9$ \\
\hline $\mathrm{V} 16$ & Open & $\mathrm{B} 9 \rightarrow \mathrm{V} 16 \rightarrow \mathrm{B} 4$ \\
\hline $\mathrm{V} 15$ & Open & $\mathrm{B} 4 \rightarrow \mathrm{V} 15 \rightarrow \mathrm{C} 3$ \\
\hline $\mathrm{V} 14$ & Open & $\mathrm{C} 3 \rightarrow \mathrm{V} 14 \rightarrow \mathrm{B} 3$ \\
\hline $\mathrm{V} 13$ & Open & $\mathrm{B} 3 \rightarrow \mathrm{V} 13 \rightarrow \mathrm{B} 10$ \\
\hline
\end{tabular}

Flow Rate (from Sheet 11 Checksheet\#___): $\mathrm{mL} / \mathrm{hr}$

Pump On: (time/date)

Observations:

Pump Off: (t ime/date)

Mass Collected (gross receiver): 9 (net collected): 
WHC-SD-RE-TPI-001, Rev. 0

Sheet 14: Config. 8: CST Subassembly Column 4 Reverse Feed Valving Configuration Checksheet and Datasheet

Executed for Test Procedure Step: Checksheet\#

Executed by:

Date/time:

Receiver/bottle tare: grams

Feed Line (L1) into Feed Tank:

Feed Material:

Density $\mathrm{g} / \mathrm{mL}$

Effluent Line (B12) into

Valve $\mathrm{Placement/Confirmation} \mathrm{(See} \mathrm{Figure} \mathrm{A}-3$ ) other valves closed:

\begin{tabular}{|l|l|l|}
\hline Valve & Position & Direction \\
\hline $\mathrm{V} 1$ & Open & $\mathrm{L} 1 \rightarrow \mathrm{V} 1 \rightarrow \mathrm{B} 1$ \\
\hline $\mathrm{V} 12$ & Open & $\mathrm{B} 1 \rightarrow \mathrm{V} 12 \rightarrow \mathrm{B} 11$ \\
\hline $\mathrm{V} 20$ & Open & $\mathrm{B} 11 \rightarrow \mathrm{V} 20 \rightarrow \mathrm{B} 7$ \\
\hline $\mathrm{V} 19$ & Open & $\mathrm{B} 7 \rightarrow \mathrm{V} 19 \rightarrow \mathrm{C} 4$ \\
\hline $\mathrm{V} 18$ & Open & $\mathrm{C} 4 \rightarrow \mathrm{V} 18 \rightarrow \mathrm{B} 6$ \\
\hline $\mathrm{V} 17$ & Open & $\mathrm{B} 6 \rightarrow \mathrm{V} 17 \rightarrow \mathrm{B} 12$ \\
\hline
\end{tabular}

Flow Rate (from Sheet 11 Checksheet\#___ ): $\mathrm{mL} / \mathrm{hr}$

Pump On: (time/date)

Observations:

Pump Off: (time/date)

Mass Collected (gross receiver): g (net collected) : 9 (Use additional sheets for mass collection if collection vessel changed) 
WHC-SD-RE-TPI-001, Rev. 0

\section{Sheet 15: CST Waste Feed Preparation}

Checksheet and Data Sheet

Objective: Prepare $1000 \mathrm{~mL}$ batch of waste feed for CST resin test.

Executed for Test Procedure Step: _ $4.2 .4 \_$Checksheet\#__

Executed by:

Date/time:

1. By mass, add $500 \mathrm{~mL}$ equivalent of waste liquor from waste sample bottles $(780 \mathrm{~g}$ at $\mathrm{SPG}=1.56)$ into $2 \mathrm{~L}$ mixing vessel.

Actual mass added / density $\mathrm{g} / \mathrm{mL})=$ $\mathrm{mL}$.

2. Add DI water to mixing vessel in aliquots to equal waste mass divided by density. Actual volume added

3. Mix on magnetic stirring plate until no crystals are visible.

4. Allow to settle, decant clear liquor into feed tank T2.

5. Tare centrifuge cones.

6. Centrifuge the waste material mixture, and decant into feed tank T2. Observations of liquor clarity, color and of any suspended solids:

7. Upon completion of waste material addition to T2, pipette a $5 \mathrm{~mL}$ aliqout into prelabeled sample vial $\mathrm{F}$ - (seq. number by batch starting at 2 )

8. Take an additional aliquot from $\mathrm{T} 2$ and submit it for density analysis.

9. Place any centrifuge solids in prelabeled sample vial FS - Iseq. number by batch starting at 2 )

10. Weigh all centrifuge cones to determine the accumulated mass.

11. Place " 1 gram of the centrifuge solids in a prelabeled sample vial FS (seq. number by batch starting at 2 ) 
WHC-SD-RE-TPI-001, Rev. 0

Sheet 16: CST Test Run Primary Column Sampling

Configuration Checksheet and Datasheet

Executed for Test Procedure Step: Checksheet\#

Executed by:

Completed Date/time:

Feed Line (L1) into Feed Tank:

Feed Material:

Sample Vial plus stopper Tare weight: g

Flush Vial Tare: g

Effluent Line (B12) into Flush Vial

Valve Placement/Confirmation: (See Figure A-3) Configuration 5

Change V17 position:

from: B5 $\rightarrow$ V17 $\rightarrow$ B6

to: $\mathrm{B} 5 \rightarrow \mathrm{V} 17 \rightarrow \mathrm{B} 12$

Flow Rate (from Sheet 11, Checksheet\#___): $\mathrm{g} / \mathrm{hr}$

Collect $\sim 2 \mathrm{~mL}$ in Flush Vial

Place line B12 into sample vial

Collect $\sim 5 \mathrm{~mL}$ in sample vial;

Time of colleciton: $\min$ $\sec$

Redirect valve $V 17$ back to 1 ine $B 6$

Change V17 position:

from: $B 5 \rightarrow V 17 \rightarrow B 12$

to: $\quad \mathrm{B} 5+\mathrm{V} 17+\mathrm{B} 6$

Weight flush: g Net flush: g

Weight Sample + stopper: g, Net sample: g

Flow rate $=$ Net sample / sample time $=$ $\mathrm{g} / \mathrm{hr}$ Observations: 


\section{Sheet 17: CST Test Run Primary Column Sample Record}

Executed for Test Procedure Step:

\section{Sample Datasheet}

Executed by:

Completed Date/time:

Run Start (Date/time):

\begin{tabular}{|c|c|c|c|c|c|}
\hline Sample & $\begin{array}{c}\text { Projected Run } \\
\text { Time }\end{array}$ & $\begin{array}{l}\text { Projected } \\
\text { Clock Time }\end{array}$ & $\begin{array}{c}\text { Actual } \\
\text { clock Time } \\
\end{array}$ & On-Line $\beta-\gamma$ & $\begin{array}{c}\text { Feed Temp. } \\
\left({ }^{\circ} \mathrm{C}\right)\end{array}$ \\
\hline C3E-1 & $1 \mathrm{hr} 30 \mathrm{~min}$ & & & & \\
\hline C3E-2 & $68 \mathrm{hr} 10 \mathrm{~min}$ & & & & \\
\hline C3E-3 & $72 \mathrm{hr} 20 \mathrm{~min}$ & & & & \\
\hline C3E-4 & $76 \mathrm{hr} 30 \mathrm{~min}$ & & & & \\
\hline C3E-5 & $80 \mathrm{hr} 40 \mathrm{~min}$ & & & & \\
\hline C3E-6 & $84 \mathrm{hr} 50 \mathrm{~min}$ & & & & \\
\hline C3E-7 & $89 \mathrm{hr} 0 \mathrm{~min}$ & & & & \\
\hline C3E-8 & $93 \mathrm{hr} 10 \mathrm{~min}$ & & & & \\
\hline C3E-9 & $97 \mathrm{hr} 20 \mathrm{~min}$ & & & & \\
\hline$C 3 E-10$ & $101 \mathrm{hr} 30 \mathrm{~min}$ & & & & \\
\hline C3E-11 & $105 \mathrm{hr} 40 \mathrm{~min}$ & & & & \\
\hline C3E- 12 & $109 \mathrm{hr} 50 \mathrm{~min}$ & & & & \\
\hline$c 3 E-13$ & $114 \mathrm{hr} 0 \mathrm{~min}$ & & & & \\
\hline C3E-14 & $118 \mathrm{hr} 10 \mathrm{~min}$ & & & & \\
\hline$C 3 E-15$ & $122 \mathrm{hr} 20 \mathrm{~min}$ & & & & \\
\hline$C 3 E-16$ & $126 \mathrm{hr} 30 \mathrm{~min}$ & & & & \\
\hline$C 3 E-17$ & $130 \mathrm{hr} 40 \mathrm{~min}$ & & & & \\
\hline$C 3 E-18$ & 134 hr 50 min & & & & \\
\hline C3E- 19 & $139 \mathrm{hr} 0 \mathrm{~min}$ & & & & \\
\hline C3E-20 & $143 \mathrm{hr} 10 \mathrm{~min}$ & & & & \\
\hline$C 3 E-21$ & $147 \mathrm{hr} 20 \mathrm{~min}$ & & & & \\
\hline$C 3 E-22$ & $151 \mathrm{hr} 30 \mathrm{~min}$ & & & & \\
\hline$C 3 E-23$ & 155 hr $40 \mathrm{~min}$ & & & & \\
\hline$C 3 E-24$ & 159 hr 50 min & & & & \\
\hline C3E- 25 & $164 \mathrm{hr} 0 \mathrm{~min}$ & & & & \\
\hline$C 3 E-26$ & $168 \mathrm{hr} 10 \mathrm{~min}$ & & & & \\
\hline$C 3 E-27$ & $172 \mathrm{hr} 20 \mathrm{~min}$ & & & & \\
\hline
\end{tabular}


WHC-SD-RE-TPI-001, Rev. 0

Sheet 18: R-F Resin Dissolution Test

Sample Datasheet

Executed for Test Procedure Step: Checksheet\#

Executed by:

Completed Date/time:

Run Start (Date/time):

Procedure:

1. In an evaporating dish, weigh out $1 \mathrm{~g}$ of $\mathrm{R}-\mathrm{F}$ resin.

2. Add $2 \mathrm{~mL}$ of $3 \mathrm{M} \mathrm{HNO}_{3}$ acid.

3. Allow - 1 hour for digestion, do not heat above $60^{\circ} \mathrm{C}$.

4. Analytically transfer to $100 \mathrm{~mL}$ volumetric flask and dilute with DI water to the mark.

5. Subsample $~-5 \mathrm{~mL}$ and retain. Label the subsample as SRF1. Observations: 
WHC-SD-RE-TPI-001, Rev. 0

Sheet 19: CST Resin Dissolution Test

Sample Datasheet

Executed for Test Procedure Step: Checksheet\#

Executed by:

Completed Date/time:

Run Start (Date/time):

Procedure:

1. In an evaporating dish, weigh out $0.1 \mathrm{~g}$ of CST resin.

2. Add $3 \mathrm{~mL}(+/-0.5 \mathrm{~mL})$ of DI water.

3, Add - I $\mathrm{mL}$ of $2 \mathrm{M} \mathrm{HCL}$.

4. Add $0.5 \mathrm{~mL}$ of $\mathrm{IM} \mathrm{HF}$.

5. Heat gently to dissolve.

6. Analytically transfer to a $100 \mathrm{~mL}$ volumetric flask and dilute with DI water to the mark.

7. Subsample $\sim 5 \mathrm{~mL}$ and retain. Label the subsample as SCST1.

observations: 
Sheet 20: Pump Calibration for the R-F Resin Column Test

\section{Sample Datasheet}

Objective: To calibrate the pump flow rate against effluent flow rates at $V 3$ (line $A 10$ ), V7 (line $A 12$ ), and $V 10$ (line $A 8$ ), using $2.5 \mathrm{M} \mathrm{NaOH}$. This

procedure will be carried out for pump flow settings of approximately $15 \%$, $40 \%, 50 \%, 60 \%$ and $75 \%$ of the pump knob range.

Executed for Test Procedure Step: Checksheet\#

Executed by:

Run Start (Date/time): Completed Date/time:

Prior to carrying out the procedure:

1. Tare the receiver bottle $(\sim 250 \mathrm{~mL})$. Note: The receiver bottle will be used and weighed at each sample point.

2. Place 1 ine $L 1$ into a feed bottle containing $250 \mathrm{~mL}$ of $2.5 \mathrm{M} \mathrm{NaOH}$.

3. Set valve positions to : Configuration 2 (Sheet 5 ).

4. Place the pump knob setting to the desired flow configuration and allow effluent to flow into a effluent collection bottle located after column C2. Once the system has been charged with the caustic solution, begin the test procedure.

Test Procedure:

1. Close Valve V10.

2. Open Valve $\mathbf{V} 3$ to Line Alo.

3. Check that the pump knob is set to the desired rate.

4. Turn on pump for 20 minutes, record time on.

5. Turn pump off, record time off, weigh the receiver.

6. Reset Valve $V_{3}$ to Line $A 3$.

7. $\mathrm{Place} L$ Line $A 12$ into the tared receiver.

8. Open Valve V7 to Line A12.

9. Turn on pump for 20 minutes, record time on.

10. Turn off pump, record time off, weigh receiver.

11. Reset Valve V7 to Line $A 6$.

12. Place $A 8$ into tared receiver.

13. Open Valve V10 to 1 ine A8.

14. Turn on pump for 20 minutes, record time on.

15. Turn off pump, close all valves, record time off, weigh receiver. 
WHC-SD-RE-TPI-001, Rev. 0

Sheet 20 Continued.

Checksheet \#

\begin{tabular}{|c|c|c|c|c|c||}
\hline \multicolumn{2}{|c|}{ Al0 Sample } & \multicolumn{2}{c|}{ Al2 Sample } & \multicolumn{2}{c|}{ A8 Sample } \\
\hline \hline $\begin{array}{c}\text { Sample } \\
\text { Time }\end{array}$ & $\begin{array}{c}\text { Sample } \\
\text { Mass (g) }\end{array}$ & $\begin{array}{c}\text { Sample } \\
\text { Time }\end{array}$ & $\begin{array}{c}\text { Sample } \\
\text { Mass (g) }\end{array}$ & $\begin{array}{c}\text { Sample } \\
\text { Time }\end{array}$ & $\begin{array}{c}\text { Sample } \\
\text { Mass (g) }\end{array}$ \\
\hline & & & & & \\
\hline & & & & & \\
\hline & & & & & \\
\hline & & & & & \\
\hline & & & & & \\
\hline
\end{tabular}

Flow:= Net Sample Mass/Sample Time

\begin{tabular}{||c|c|c||}
\hline $\begin{array}{c}\text { Al0 } \\
\text { Sample }\end{array}$ & $\begin{array}{c}\text { Al2 } \\
\text { Sample }\end{array}$ & $\begin{array}{c}\text { A8 } \\
\text { Sample }\end{array}$ \\
\hline \hline $\begin{array}{c}\text { Flow } \\
\text { rate }\end{array}$ & $\begin{array}{c}\text { Flow } \\
\text { rate }\end{array}$ & $\begin{array}{c}\text { Flow } \\
\text { rate }\end{array}$ \\
\hline & & \\
\hline & & \\
\hline & & \\
\hline & & \\
\hline & & \\
\hline
\end{tabular}


WHC-SD-RE-TPI-001, Rev. 0

Sheet 21: Pump Calibration for the CST Resin Column Test

Sample Datasheet

Objective: To calibrate the pump flow rate against effluent flow rates at V13 ( 1 ine $\mathrm{B10}$ ), V17 (1 ine B12), and $\mathrm{V} 20$ (1 ine B8), using $2.5 \mathrm{M} \mathrm{NaOH}$. This procedure will be carried out for pump flow settings of approximately $15 \%$, $40 \%, 50 \%, 60 \%$ and $75 \%$ of the pump knob range.

Executed for Test Procedure Step: Checksheet\#

Executed by:

Run start (Date/time): Completed Date/time:

Prior to carrying out the procedure:

1. Tare the receiver bottle $(\sim 250 \mathrm{~mL})$. Note: The receiver bottle will be used and weighed at each sample point.

2. Place line $\mathrm{L} 1$ into a feed bottle containing $300 \mathrm{~mL}$ of $2.5 \mathrm{M} \mathrm{NaOH}$.

3. Set valve positions to : Configuration 6 (Sheet 12).

4. Place the pump knob setting to the desired flow configuration and allow effluent to flow into a effluent collection bottle located after column C4. Once the system has been charged with the caustic solution, begin the test procedure.

Test Procedure:

1. Close Valve V20.

2. Open Valve V13 to Line B10.

3. Check that the pump knob is set to the desired rate.

4. Turn on pump for 20 minutes, record time on.

5. Turn pump off, record time off, weigh the receiver.

6. Reset Valve V13 to Line B3.

7. P1ace Line $B 12$ into the tared receiver.

8. Open Valve V17 to Line B12.

9. Turn on pump for 20 minutes, record time on.

10. Turn off pump, record time off, weigh receiver.

11. Reset Valve V17 to Line B6.

12. Place $B 8$ into tared receiver.

13. Open Valve V20 to $l$ ine B8.

14. Turn on pump for 20 minutes, record time on.

15. Turn off pump, close all valves, record time off, weigh receiver. 
WHC-SD-RE-TPI-001, Rev. 0

Sheet 21 Cont inued.

Checksheet \#

\begin{tabular}{||c|c|c|c|c|c||}
\hline \multicolumn{2}{|c|}{ Bl0 Sample } & \multicolumn{2}{c|}{ B12 Sample } & \multicolumn{2}{c|}{ B8 Sample } \\
\hline \hline $\begin{array}{c}\text { Sample } \\
\text { Time }\end{array}$ & $\begin{array}{c}\text { Sample } \\
\text { Mass (g) }\end{array}$ & $\begin{array}{c}\text { Sample } \\
\text { Time }\end{array}$ & $\begin{array}{c}\text { Sample } \\
\text { Mass (g) }\end{array}$ & $\begin{array}{c}\text { Sample } \\
\text { Time }\end{array}$ & $\begin{array}{c}\text { Sample } \\
\text { Mass (g) }\end{array}$ \\
\hline & & & & & \\
\hline & & & & & \\
\hline & & & & & \\
\hline & & & & & \\
\hline
\end{tabular}

Flow:= Net Sample Mass/Sample Time

\begin{tabular}{||c|c|c||}
\hline $\begin{array}{c}\text { BI0 } \\
\text { Sample }\end{array}$ & $\begin{array}{c}\text { B12 } \\
\text { Sample }\end{array}$ & $\begin{array}{c}\text { B8 } \\
\text { Sample }\end{array}$ \\
\hline \hline $\begin{array}{c}\text { Flow } \\
\text { rate }\end{array}$ & $\begin{array}{c}\text { Flow } \\
\text { rate }\end{array}$ & $\begin{array}{c}\text { Flow } \\
\text { rate }\end{array}$ \\
\hline & & \\
\hline & & \\
\hline & & \\
\hline & & \\
\hline & & \\
\hline
\end{tabular}


WHC-SD-RE-TPI-001, Rev. 0

Sheet 22: R-F Resin Dissolution

Objective: To remove and dissolve the R-F resin at the end of the test. The dissolved resin from Column $\mathrm{Cl}$ will be sampled and submitted for analysis by $A E A, I C P$ and GEA.

Checksheet \#

Resin Dissolution:

Prior to carrying out the procedure:

1. Confirm the following valve positions:

C1 V4 \& V5 off

C2 V8 \& Vg off

2. Crimp the tubing to inhibit leaks, two crimps approximately l" apart on each side of the column.

Procedure:

1. Remove column $\mathrm{Cl}$ from the retainers.

2. Cut the line between the crimps above and below the column.

3. Remove the top of the column.

4. Deposit the resin into a receiver by scraping and rinsing.

5. From the determination of the amount of acid needed (Sheet 18), digest proportionatly, sampling as SRF2, SRF3, and SRF4 using prelabeled sample vials.

6. Digest the resin in Column $\mathrm{C} 2$ in the same manner, no samples are to be taken. Slurp the remaining resin. 
Sheet 23: CST Resin Dissolution

Objective: To remove and dissolve the CST resin at the end of the test. The dissolved resin from Column C3 will be sampled and submitted for analysis by $A E A, I C P$ and GEA.

\section{Checksheet \#}

Resin Dissolution:

Prior to carrying out the procedure:

1. Confirm the following valve positions:

\section{C3 V14 \& V15 off}

C4 V18 \& V19 Off

2. Crimp the tubing to inhibit leaks, two crimps approximately l" apart on each side of the column.

Procedure:

1. Remove column C3 from the retainers.

2. Cut the line between the crimps above and below the column.

3. Remove the top of the column.

4. Deposit the resin into a receiver by scraping and rinsing.

5. From the determination of the amount of acid needed (Sheet 19), digest proportionatly, sampling as SCST2, SCST3, and SCST4 using prelabeled sample vials.

6. Digest the resin in Column $\mathrm{C} 4$ in the same manner, no samples are to be taken. Slurp the remaining resin. 
WHC-SD-RE-TPI-001, Rev. 0

Sheet 24: R-F Resin Bed Density Determination

Objective: To determine the volume to mass ratio of the conditioned $R-F$ resin.

Checksheet \#

Procedure:

1. Dry approximately 5 grams of resin in a tared evaporating dish at $103^{\circ} \mathrm{C}$ for 4 hours.

2. Cool in a dessicator and weigh on an analytical balance.

Weight of the resin + evap dish:

Weight of the evaporting dish: g

Weight of the R-F Resin: 9

3. Wash the resin to remove fines in a $250 \mathrm{~mL}$ beaker with a magnetic stirrer, allow the resin to settle, carefully decant the water without disturbing the resin. Repeat until fines are removed.

4. After the fines are removed, condition the resin as per specifications in the TPI 4.2.2.

5. After the resin is conditioned, analytically decant into a volumetric cylinder. Allow the resin to settle and record the volume.

6. Analytically decant the resin into a tared evaporating dish and dry at $103^{\circ} \mathrm{C}$ for 4 hours.

Weight of the resin + evap dish: g

Weight of the evaporting dish:

Weight of the R-F Resin: 9

Volume occupied by the resin: $\mathrm{mL}$ Mass $/$ Volume $=$ $\mathrm{g} / \mathrm{mL}$ 
WHC-SD-RE-TPI-001, Rev. 0

Sheet 25: CST Resin Bed Density Determination

Objective: To determine the volume to mass ratio of the conditioned CST resin.

Checksheet

Procedure:

1. Dry approximately 5 grams of resin in a tared evaporating dish at $103^{\circ} \mathrm{C}$ for 4 hours.

2. Cool in a dessicator and weigh on an analytical balance.

Weight of the resin + evap dish: 9

Weight of the evaporting dish: g

Weight of the CST Resin: 9

3. Wash the resin to remove fines in a $250 \mathrm{~mL}$ beaker with a magnetic stirrer, allow the resin to settle, carefully decant the water without disturbing the resin. Repeat until fines are removed.

4. After the fines are removed, condition the resin as per specifications as per specifications provided by the manufacturer.

5. After the resin is conditioned, analytically decant into a volumetric cylinder. Allow the resin to settle and record the volume.

6. Analytically decant the resin into a tared evaporating dish and dry at $103^{\circ} \mathrm{C}$ for 4 hours.

Weight of the resin + evap dish:

Weight of the evaporting dish:

Weight of the CST Resin:

Volume occupied by the resin:

$\mathrm{mL}$

Mass $/$ Volume $=$ $\mathrm{g} / \mathrm{mL}$ 
WHC-SD-RE-TPI-001, Rev. 0

THIS PAGE INTENTIONALLY LEFT BLANK 
WHC-SD-RE-TPI-001, Rev. 0

Appendix B: Material Safety Data Sheets 
WHC-SD-RE-TPI-001, Rev. 0

THIS PAGE INTENTIONALLY LEFT BLANK 


\section{List of Material Safety Data Sheets}

Sodium Hydroxide, $\mathrm{NaOH} \ldots \ldots \ldots \ldots \ldots \ldots \ldots \ldots \ldots \ldots$ B-1

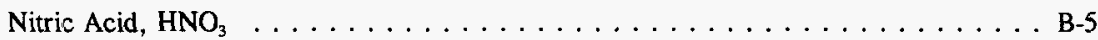

Hydrofluoric Acid, HF . . . . . . . . . . . . . . B-7

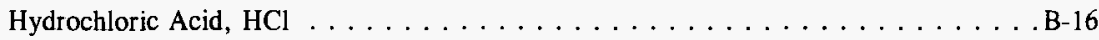

Resorcinol-Formaldehyde Resin, R-F . . . . . . . . . . . . . . . B-21

UOP IONSIV Ion Exchanger Type IE-911 (Crystalline Silicotitanate) $\ldots \ldots \ldots \ldots$. B-23

\section{MSDS Numbers}

Sodium Hydroxide, $\mathrm{NaOH} \ldots \ldots \ldots$. . . . . . . . . . . . . . . . . 045620

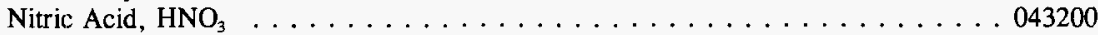

Hydrofluoric Acid, HF . . . . . . . . . . . . . . . . . . . . . . . . . 039275

Hydrochloric Acid, HCl . . . . . . . . . . . . . . . . . . . . . 036338

Resorcinol-Formaldehyde Resin, R-F . . . . . . . . . . . . . . . 023312

UOP IONSIV Ion Exchanger Type IE-911 (Crystalline Silicotitanate) . . . . . . 053329 
WHC-SD-RE-TPI-001, Rev. 0

THIS PAGE INTENTIONALLY LEFT BLANK

B-iv 

Product : S0899 Name: SODIUM HYDROXIDB PBLLETS ACS REAGENT Material Safety Daca Sheet Valid 2/95- 4/95 Printed: 02/22/1995 15:33:32

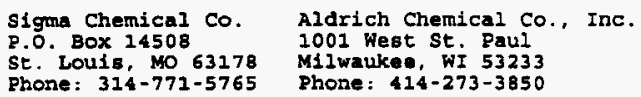

Aldrich Chemical Co., Inc. 1001 West St. Paul M1lwaukee, WI 53233

Phone : 414-273-3850

\section{MSDS \#045620}

\section{Fluka Chemical corp.} 980 South Second st. Ronkonkoma, NY 11779 Phone: $516-467-0980$

Emergency Phone: 516-467-3535

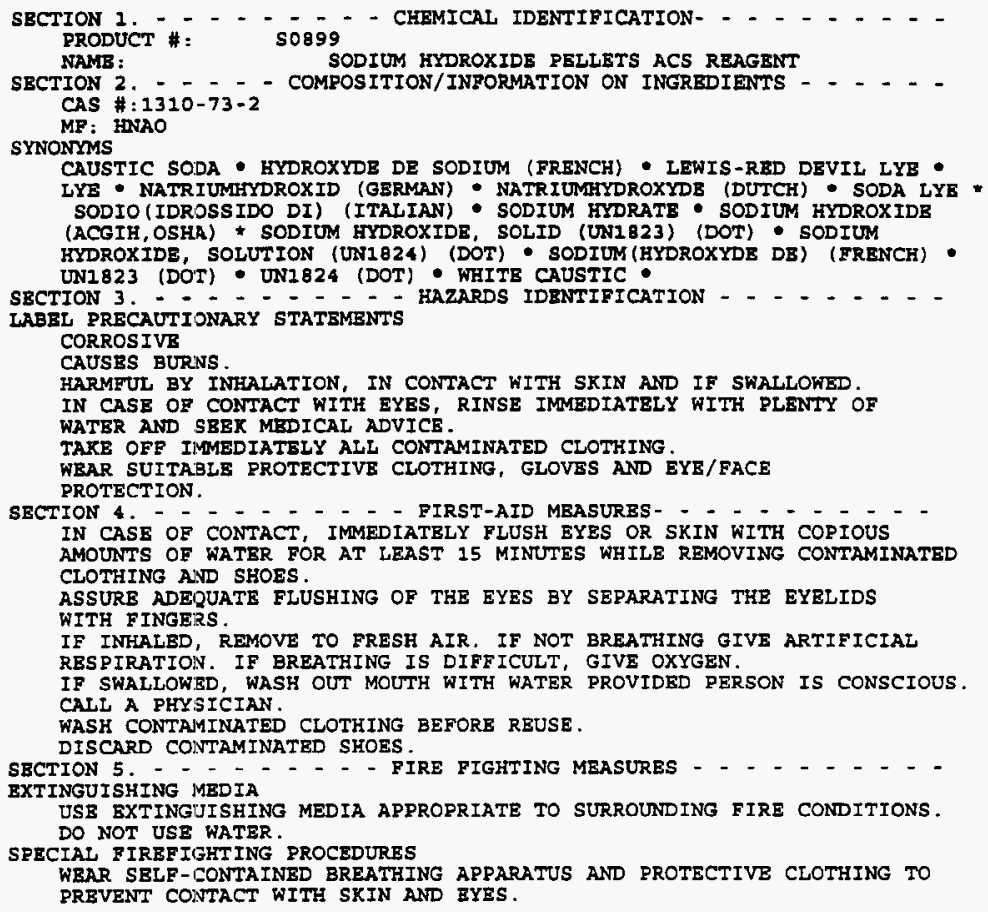




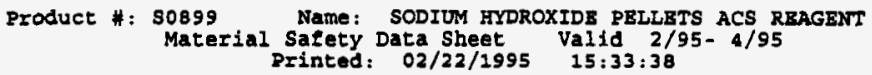

UNUSUAL FIRE AND EXPLOSIONS HAZARDS

MSDS \#045620

BMITS TOXIC FUMES UNDBR FIRE CONDITIONS.

SBCTION 6. - - - - _ - ACCIDENTAL RELEASE MEASURES - - - - . -

EVACUATE AREA.

WEAR SELF-CONTAINED BREATHING AFPARATUS, RUEGER BOOTS AND HEAVY

RUBBER GLOVBS

SWEBP UP, PLACE IN A BAG AND ROLD FOR NASTE DISPOSAL.

VBNTILATE AREA AND WASH SPILL SITE AFTER MATERIAI PICKUP IS COMPLETE.

SECTION 7. - - - - - - - HANDLING AND STORAGE- - - - - - - -

REFER TO SECTION 8 .

ADDITIONAL INFORMATION

CONTACT WITH ALUMINUN, TIN AND ZINC LIBERATES HYDROGEN GAS. CONTACT WITH NITROMETHANE AND OTHER SIMILAR NITRO COMPOUNDS CAUSES FORMATION OF SHOCK-SENSITIVE SALTS.

SECTION B . - - - - - EXPOSURE CONTROLS/RERSONAL PROTECTION - - - - WEAR APPROPRIATE NIOSH/MSHA-APPROVED RESPIRATOR, CHEMICAL-RESISTANT GIOVES, SAFETY GOGGLBS, OTHER PROTECTIVE CLOTHING.

SAFETY SHOWER AND EYE BATH.

USE ONLY IN A CHEMICAL FUNE HOOD.

FACESHIELD (8-INCH MINIMUM).

DO NOT BREATHB DUST.

DO NOT GET IN EYES, ON SKIN, ON CLOTHING.

AVOID FROLONGED OR REEEATED EXPOSURE.

READILY ABSORBED TEROUGH SKIN.

WASH THOROUGELY AETER HANDLING.

TOXIC.

CORROSIVR.

XERP TIGHTLY CLOSED.

EXTREMELY HYGROSCOPIC

AIR SENSITIVE

STORE IN A COOL DRY PLACE.

SBCTION 9. - - - - - - PHYSICAL AND CHEMICAL PRORERTIES - - - - -

APPRARANCE AND ODOR

WHITE PELLETS

MELTING POINT: $318 \mathrm{C}$

VAPOR PRESSURE: $\quad 18 \mathrm{MM} 20 \mathrm{C} \quad 3 \mathrm{MM} 37 \mathrm{C}$

VAPOR DENSITY: $>1$

SPECIFIC GRAVITY: 2.130

SECTION 10. - - - - - - STABILITY AND REACTIVITY - - - - -

INCOMPATIBILITIES

STRONG OXIDIZING AGENTS

STRONG ACIDS

ORGANIC MATERIALS

CHLORINATED SOLVENTS

ABSORBS CO2 FROM AIR.

PROTECT FROM MOISTURE.

HAZARDOUS COMBUSTION' OR DECOMPOSITION PRODUCTS

NATURE OF DECOMPOSITION PRODUCTS NOT KNOWN

SECTION 11, - - - . - . - TOXICOZOGICAL INFORMATION - . - . - - 

Product \#: S0899 Name: SODIUM HYDROXIDE PELLETS ACS REAGENT Material Sacty Data Sheet Valid 2/95- $4 / 95$ Printed: $02 / 22 / 1995 \quad 15: 33: 43$

\section{ACUTE EFFECTS}

\section{MSDS \#045620}

FARMFUL II SWALLOWBD, INTALED, OR ABSORBED THROVGH SKIN

MATERIAL IS EXTREMELY DESTRUCTIVB TO IISSUE OF THE MUCOUS MEMBRANES AND UPPER RESPIRATORY TRACT, EYES AND SKIN.

CAUSBS SEVBRE BURNS.

INHALATION MAY BE FATAL AS A RESULT OF SPASM, INFIAMMATION AND BDEMA OF THE LARYNX AND BRONCHI, CHBMICAL PNBUMONITIS AND PULMONARY EDEMA. SYMPTOMS OE EXPOSURB MAY INCLUDE BURNING SENSATION, COUGHING, WHEEING, LARYNGITIS, SHORTWESS OE BRIATH, HBADACHE, NAUSEA AND VOMITING.

TO THB BEST OF OUR INOWLEDGE, THE CHEMICAL, PHYSICAL, AND TOXICOLOGICAL PRORBRTIES HAVE NOT BEEN THOROUGHLY INVESTIGATED.

RTECS NO: WB 4900000 SODIUM FYIROXIDE

IRRITATION DATA

EYE-MKY 1\%/24H SEV

SKN-RBT $500 \mathrm{MG} / 24 \mathrm{H}$ SEV

EYE-RBT 400 UG MLD

TXAPA9 $6,701,64$

EYE-RBT 1\%; SEV

BYE-RBT 50 UG/24H SEV

EYE-RBT $1 \mathrm{MG} / 24 \mathrm{H}$ SBV

EYE-RBT 1 MG/3OS RINSE SEV

TOXICITY DATA

IPR-MUS LD50:40 MG/KG

$28 Z$ PAK $-, 7,72$

OYYAA2 $26,627,83$

AJOPAA $29,1363,46$

28ZPAK $-, 7,72$

TXAPA9 $6,701,64$

IXCYAC $23,281,82$ (RTECS) DATA IS PRESENTED HERE. SEE ACTUAL BNTRY IN RTBCS FOR COMPLETE JNFORMATION.

SBCTION 12 . - - - - - - ECOLOGICAI INEORMATION - - - - - - DATA NOT YET AVAILABLE.

SECTION 13. - - - - - - - - DISPOSAL CONSIDERATIONS - - - - - - - FOR SMALL QUANTITIES: CAUTIOUSIY ADD TO A IARGE STIRRED EXCESS OE WATER. ADUTST THE PH TO NBUTRAL, SEPARATE ANY INSOLUBLE SOLIDS OR LIQUIDS AND PACKAGE THEM POR HAZARDOUS-WASTE DISPOSAL. FLUSH THE AQUEOUS SOLUTION DOWN THE DRAIN WITH PLEWTY OF WATER. THE HYDROLYSIS AND NEUTRALIZATION REACTIONS MAY GBNERATE HEAT AND EUMES WHICH CAN BE CONTROLLELI BY THE RATE OF ADDITION.

OBSERVE AILL FEDERAL, STATE AND LOCAL ENVIRONMENTAL REGULATIONS.

SECTION 14. - _. - - - - - TRANSPORT INFORMATION - - - - . - . CONTACT SIGMA CHEMICAL COMPANY FOR TRANSPORTATION INEORMATION.

SBCTION 15. - - - - - - REGULATORY INFORMATION - - - - - - . RBVIBWS, STANLIARDS, AND REGULATIONS

ACGIH TLV-CL 2 MG $/ M 3$

85INAB $6,1416,91$

BPA FIFRA 1988 PESTICIDE SUBJECT TO REGISTRATION OR RE-REGISTRATION

FEREAC 54,7740,89

MSFA STANLARD:AIR-CL $2 \mathrm{MG} / \mathrm{M3}$

DTLVS* 3,233,71

OSHA PEL: EH TWA 2 MG/M3

FEREAC $54,2923,89$

OSHA PEL FINAL:CL 2 MG/M3 
FERBAC 54,2923,89 OBL-AUSTRALIA: TWA 2 MG/M3 JAN93

MSDS\#045620 OEL-BELGIUM: STEL 2 MG/M3 JAN9 3 OBL-DENMARK: TWA 2 MG/M3 JAN93 OEL-FINIAND: TWA 2 MG/M3 JAN93 OBL, PRANCR : TWA 2 MG/M3 JAN93 OEL-GBRMANY: TWA 2 MG/M3 JAN93 3 OEL-JAPAN:STEL 2 MG/M3 JAN93

OBL-THE NBTHERLANDS:TWA 2 MG/M3 JAN93 OBL-THE PHILIPPINES:TWA 2 MG/M3 JAN93

OEL-SWEDEN: TWA 2 MG/M3 JAN93

OEL-SWITZBRLAND:TWA 2 MG/M3;STEL 4 MG/M3 JAN93

OEL-THAILAND: TWA 2 MG/M3 JAN93

OEL-TURKEY : TWA 2 MG/M3 JAN93

OEL-UNITED XINGDOM: TWA 2 MG/M3, STEL 2 MG/M3 JAN9 3

OEL IN BULGARIA, COLOMBIA, JORDAN, KORBA CHECK ACGIH TLV

OBL IN NBW ZBALAND, SINGAPORE, VIETNAM CHECK ACGIH TLV

NIOSH RBI TO SODIUM HYDROXIDE-AIR:CL 2 MG/M3/15M

NIOSH* DHHS \#92-100,92

NOHS 1974: HZD 69070; NIS 359; TNF 112525; NOS 192; TNE 1122583

NOES 1983; HZD X3782; NIS 164; TNF 20410; NOS 117; TNE 332750 ; TFE 123903

NOES 1983: H2D 69070; NIS 394; TNF 107562; NOS 231; TNE 2233346; TFE 740163

BPA GENETOX PROGRAM 1988, NEGATIVE: CELI TRANSFORM. -SA7/SHR

BEA TSCA CHBMICAL INVENTORY, JUNB 1993

BPA TSCA SECTION \& (E) STATUS REPORT 8EHQ-0485-0552

BPA TSCA TEST SUBMISSION (TSCATS) DATA BASE, TUTY 1994

NIOSH ANALYTICAL METHODS : SBE ALRALINE DUSTS, 7401

SECTION 16. - - - - - - - OTHER INEORMATION - - - . - - - -

THE ABOVE INFORMATION IS BELIEVED TO BE CORRECT BUT DOES NOT PURPORT TO

BZ ALL INCLUSIVB AND SHALI BE USED ONLY AS A GUIDE. SIGMA, ALDRICH,

FLUXA SHALL NOT BE HELD LIABLE FOR ANY DAMAGE RESULTING FROM HANDLING

OR FROM CONTACT WITH THE ABOVE PRODUCT. SEE RBVERSE SIDE OF INVOICE OR

PACKING SLIP FOR ADDITIONAL TERMS AND CONDITIONS OF SALE.

COPYRIGET 1994 SIGMA CHEMICAL CO., ALDRICH CHRMICAL CO., INC.,

FLUKA CHEMIE AG

LICBNSE GRANTED TO MAKE UNLIMITED PAPER CORIES FOR INTERNAL USE ONLY 


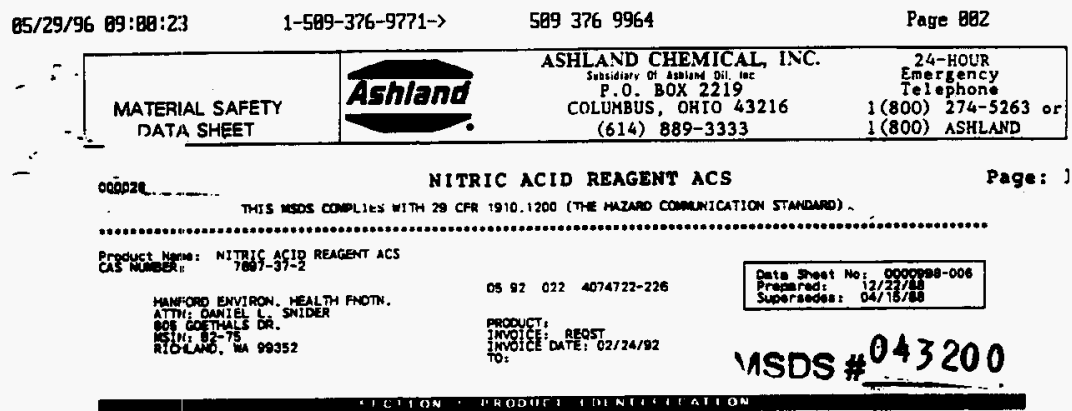

Gemeral or Generic ID: Jhomanic ACio

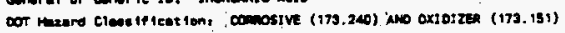

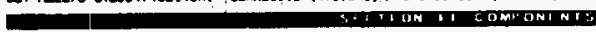

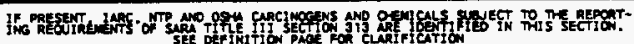

$\begin{array}{lllll}\text { Jueneorar } & \times(0) \text { WT) } & \text { PEL } & \text { TV } & \text { Note }\end{array}$

NITRES ACIP, :607-37-2

Notes:

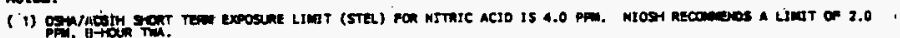
THIS DENICAL is SUENECT TO THE REPORTIKC MEOUTREENTS OF SECTION 313 OF SARA TITLE III.

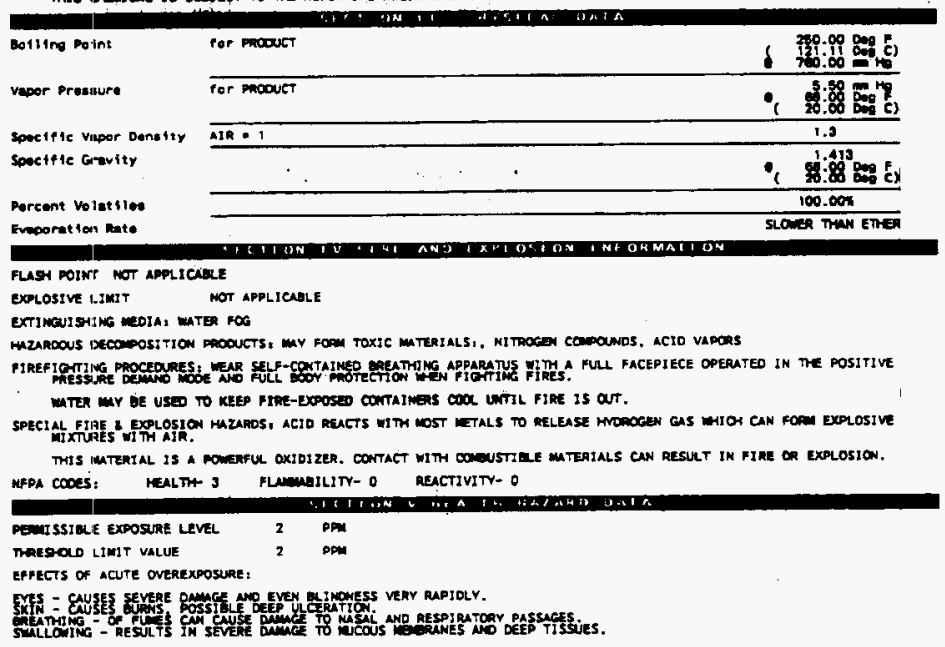




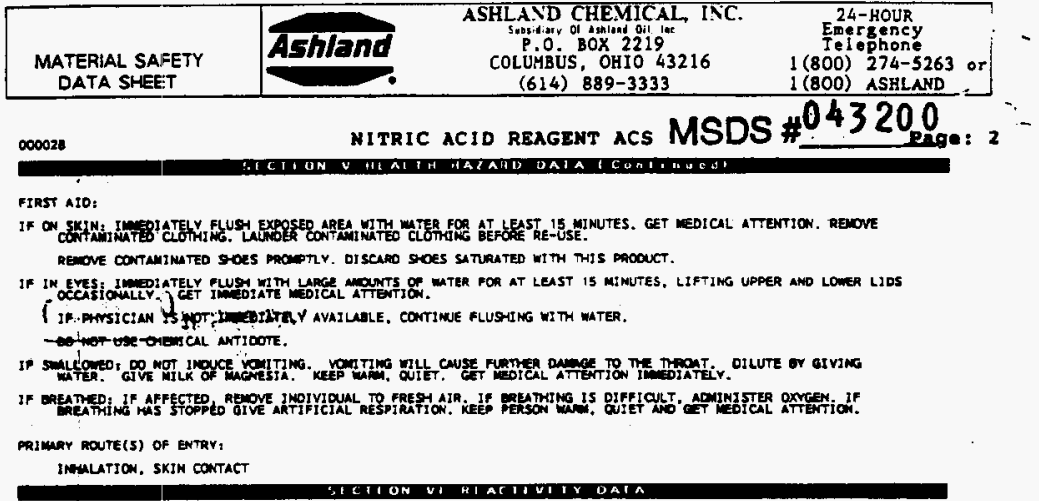

mazanoous por nerization: cannot occun

STABILITV: STABLE

INCOFATIEILITY, AWOID CONTACT WITHa, STRONG ALKALIES, ORGANIC MATERIALS, REDUCING ACENTS

JTES TO BE TAKEN IN CASE MATENAL IS RELESEO OA SPILLED:

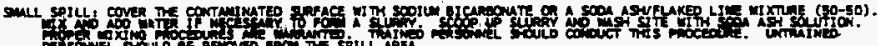

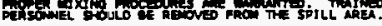

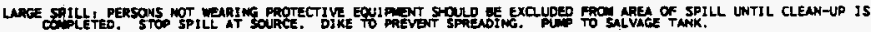

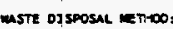

SMLL SPILL: OISPOSE OF IN ACCORANCE WITH ALL LOCAL. STATE NO FEDERAL RECULATIONS.

DI SPOSE of IN ACCOROANCE WITH ALL LOCAL, STATE AND FEDERAL RECULATIONS.

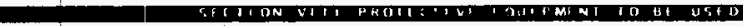

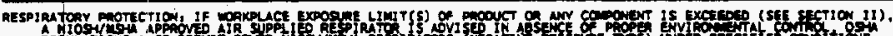

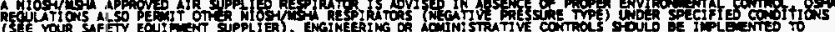

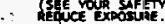

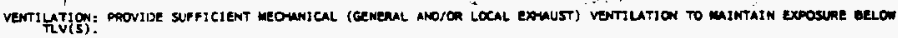

DROTECTIVE CLONES: WEAR RESISTANT ELOVES SUOH AS:. NEOPRENE, POLWINYL OLLOIDE

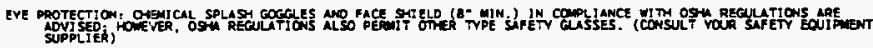

OTER PROTECTIVE EIXIPEENT: TO PREVENT SKIN CONTACT. WAR INPERYOUS CLOTMING ANO BCOTS.

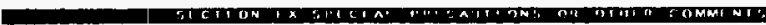

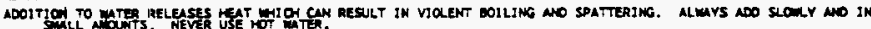

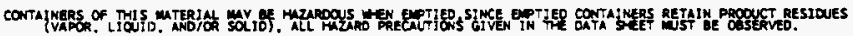

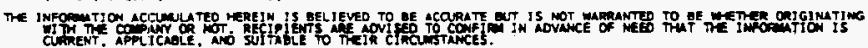


SUBSTANCE IDENTIFICATION

SUDSTANCE: IIYLROFLUORTC ACID REAGENT ACS

CAS-NUMBER 7664-39-3

TRADE NAMES/SY'NONYMS:

MSDS $\# 039275$

FLUORTC ACII; HYDROFLUORIC ACID SOLUTION; UN 1790; RCRA U134; UIF; OIIS11172

CHEMICAL FAMILY:

INORGANIC ACII

MOLECULAR FOREIULA: II-F

CERCLA RATINGS (SCALB 0-3): IIEALTII=3 FIRE=0 REACTIVITY=1 PERSISTENCE=0 NIPA RATINGS (SCALE 0-4): UIEALTII $=4$ TIRE=0 REACTIVITY $=1$

COMPONENTS AND CONTAMINANTS

COMPONENT: IIYIROGEN FLUORIDE

PERCENT: 49.0

COMPONENT: WATER

PERCENT: 51.0

\section{EXPOSURE LIHITS:}

HYDROOEN FLUOKIDE, AS F:

3 PPM OSIIA TWA; 6 PPM OSIIA STEL

3 PPH (2.5 MG/M3) ACGIII CEILING

3 PPM (2.5 HG/M3) NIOSI RECOMMENDED 10 HOUR TWA:

6 PPM (5 MG/M3) NIOSII RECOMMENDED 15 MINUTE CEILING

100 POUNDS SARA SECTION 302 TIRJSIIOLD PLANNING QUANTITY

100 POUNDS SARA SECTION 304 REPORTABLE QUANTITY

100 POUNDS CERCLA SECTION 103 REPORTABLE QUANTITY

SUDJECT TO SARA SECTION 313 ANNUAL TOXIC CIIEMICAL RELEASE REPORTING

PIIYSICAL DATA

DESCRIPTION: COLORLESS TO SLIGIITLY YELLOW LIQUID WITH A PUNGENT ODOR.

BOILING POINT: $225 \mathrm{~F}(107 \mathrm{C})$ MELTING POINT: -35 F $(-37 \mathrm{C})$ (APPROX.)

SPECIFIC GRAVITY: 1.15-1.18 VAPOR PRESSURE: 25 MMHG 2 20C PII: <2

SOLUBILITY IN WATER: SOLUBLE 
FIRE AND EXPLOSION ILAZARD:

NEGLIGIBLE FIRE IIAZARD WHEN EXPOSED TO IIEAT OR FLAME.

\section{$\operatorname{MBDS} \approx \perp 039275$}

FIREFIOHTING MEDIA:

DRY CIIDMICAL, CARBON DIOXIDE, HALON, WATER SPRAY OR ALCOIIOL FOAY

(1987 EHERGENCY RESPONSE GUIDEBOOK, DOT P 5800.4).

FOR LARGER FIRES, USE WATER SPRAY, FOG OR STANDARD FOAM (1987 EMERGENCY RESPONSE QUIDEDOOK, DOT $P$ 5800.4).

FIREFIGITING :

HOVE CONTAINERS FROM FIRE AREA IF POSSIDLE, COOL CONTAINERS EXPOSED TO ILAMES WITH WATER FROH STDE UNTIL WELL AFTER FIRE IS OUT. STAY AWAY FROH STORAGE TANK ENDS ( 1987 EMERGENCY RESPONSE GUIDEDOOK, DOT P 5800.4, OUIDE PAGE 59 ).

DO NOT USE WATER ON MATERIAL. EXTINGUISII USING AGENTS SUITABLE FOR TYPE OF FIRE, USE FLOODINO AMOUNTS OF WATER AS FOG, COOL CONTAINERS WITH FLOODINO AMOUNTS OF WATER, APPLY FROM AS FAR AISTANCE AS POSSIBLE. AVOID BREATHING CORROSIVE VAPOIRS, KEEP UPWIND.

\section{TRANSPORTATION DATA}

DEPARTMENT OF TRANSPORTATION HAZARD CLASSIFICATION 49CFR172.101: CORROSIVE MATERIAL

DEPARTMENT OF TRANSPORTATION LABELING REQUIREMENTS 49CFR172.101 AND SUDPART E: CORROSIVE

DEPARTHENT OF TRANSPORTATION PACKAQING REQUIREMENTS: 49CFR173.264 EXCEPTIONS: 49 CFR173.244

TOXICITY

HYDROGEN FLUOFIDE:

50 MG EYE-IIUMAN SEVERE IRRITATION; $100 \mathrm{MG} / \mathrm{M3} / 1$ MINUTE INHALATION-MAN TCLO;

50 PPM/30 MINUTES INHALATION-HUMAN LCLO; 1276 PPM/1 IIOUR INIIALATION-RAT LC50;

342 PPM/I IOUI INHALATION-MOUSE LCSO; 1774 PPM/I HOUR INHALATION-HONKEY LC5O;

$260 \mathrm{MG} / \mathrm{M3} / 7$ HOURS INHALATION-RABDIT LCLO; 4327 PPH/15 MINUTES

INIALATION-GUINEA PIG LC5O; 500 HG/KG SKIN-MOUSE LDLO; $25 \mathrm{MG/KG}$

INTRAPERITONEAL-RAT LDLO; MUTAGENIC DATA (RTECS); REPRODUCTIVE EFFECTS DATA

(RTECS).

CARCINOGEN STATUS: NONE.

IIYDROGEN FLUORIDE IS TOXIC AND A SEVERE EYE, SKIN AND MUCOUS MEMBRANE

IRRITANT. CHRONIC EXPOSURE MAY PRODUCE FLUOROSIS OF THE SKELETAL SYSTEM.

- HEALTH EFFECTS AND FIRST AID

INIALATION :

IIYDROGEN FLUORIDE:

CORROSIVE/TOXIC, 30 PPM IMMEDTATELY DANORROUS TO LIFE OR IIEALTII.

ACUTE EXPOSURE- TWO HUMAN SUDJECTS EXPOSED TO 120 PPM EXPERTENCED MARKED RESPIRATORY IRRITATION. TIIS WAS THE HIGHEST CONCENTRATION TILT COULD BE JOLERATED FOR MORE THAN ONE MINUTE. 30 PPM CAUSED MILD NASAL IRRITATION 
AND COULD BE TOLERATED FOR SEVERAL MINUTES. HIGIER CONCENTRATIONS MAY CAUSE TRANSIENT CHOKING, COUGIING, CIILLS, CIIEST PAIN AND CONSTRICTION, AND DYSPNEA. AN ASYMPTOHATIC PERIOD OF 12-48 HOURS MAY BE FOLLOWED BY FEVER, COUGI, DYSPNEA, CYANOSIS, RALIS, AND PULMONARY EDEMA OR DRONCHIAL PNEUMONIA. IN HUYANS, KIDNEY DAMAOE HAS ONLY BEEN REPORTED IN SEVERE, ACUTE OVEREXPOSURES. IN FOUR SEPARATE EVENTS, 9 WORKERS WERE SPLASIIED WITI IIYDROFLUOITC ACID; 6 DIED. DEATI OCCURRED 2-10 HOURS AFTER EXPOSURE AND WAS CAUSED BY PULMONARY EDEMA, IIEMORRHAGIC PULMONARY EDEMA AND ULCERATIVE TRACHEOBRONCHITIS, OR CARDIAC ARREST, IN ONE INSTANCE, THE BREATHING ZONE CONCENTRA?IION WAS ESTIMATED TO BE ADOVE 10,000 PPY.

CHRONIC EXPOSURE- 5 IIUMAN SUBJECTS EXPOSED 6 IIOURS/DAY, 5 DAYS/WEBK, FOR 10-50 DAYS AT AVERAGE CONCENTRATIONS OF UP TO 4.7 PPH EXPERIENCED SLIGIIT NASAL IRRITATION. REPEATED EXPOSURE TO LOW CONCENTRATIONS MAY CAUSE NASAL CONOESTION, NOSEDLEEDS, SINUS PROBLEMS, AND BRONCIITIS. ABSORPTION OF EXCESSIVE AMOUNTS OF FLUORINE MAY RESULT IN FLUOROSIS, A SYNDROME CIIARACTIRJZED BY OSTEOSCLEROTIC BONE CIIANGES. CASES OF VARYING DEgREES OF OSTEOSCLETOSIS ITAVE DEEN REPORTED IN WORKERS EXPOSED TO HYDROGEN FLUORIDE FOR A NUMHER OF YEARS, USUALLY 3 OR MORE. THE FIRST EVIDENCE OF CIIANGE IS MOST APPAIENT IN THE PELVIS AND LUMBAR SPINE AND MAY BE ACCOMPANIED BY MILD TO MODERATE DACK PAIN AND STIFFNESS. PRESUMADLY, OTIER SYMPTOMS OF FLUOROSIS, WEIGKT LOSS, GENERAL ILL HEALTH, ANENIA, BRITTLENESS OF TIE DONES, AND DISCOLORATION OF DEVELOPING TEETH, ARE ALSO POSSIBLE. ANIMAL STUDIES INDICATE THAT REPEATED EXPOSURE MAY CAUSE PULMONARY, HEPATIC AND RENAL TISSUE DAMAGE. EXPOSURE OF PREGNANT RATS FOR 22 DAYS RESULTED IN IN EFTECTS ON FERTILITY AND ON THE FETUS.

FIRST AID- REMOVE FROM EXPOSURE AREA TO FRESII AIR IMMEDIATELY. IF BREATHINO IHAS STOPPED, GIVE ARTIFICIAL RESPIRATION. MAINTAIN AIRWAY AND BLOOD PRESSURE ANI) ADMINISTER OXYGEN IF AVAILADLE. KEEP AFFECTED PERSON WARM AND AT REST. TREAT SYMPTOKATICALLY AND SUPPORTIVELY. ADMINISTRATION OF OXYGEN SIIOULD BE PERFORMED BY QUALIFITD PERSONNEL. GET MEDICAL ATTENTION IMMEDIATELY.

SKIN CONTACT:

HYDROGEN FLUOFIDE:

CORROSIVE.

ACUTE EXPOSURE- IIYDROGEN FLUORIDE BURNS ARE CIIARACTERIZED BY A BLANCHED APPEARANCI: OF THE SKIN WITI PERSISTENT EXCRUCIATINO PAIN, EDEMA AND NECROSIS. WITI CONCENTRATIONS LESS TIAN 20\%, PAIN AND ERYTHEMA MAY OCCUR AFTER A LATENT PERIOD OF 24 HOURS. WITH 20-5OX SOLUTIONS, BURNS MAY DE APPARENT WITHIN 1-B IOURS. WITII CONCENTRATIONS GREATER THAN 50\%, IMMEDIATE PAIN AND RAPIDLY APPARENT TISSUE DAMAGE OCCUR ON CONTACT. SMALL AMOUNTS OF HYDROGEN FLUORIDE WIIICII ARE NOT WASHED OFF MAY CAUSE DELAYED DEVELOPMENT OF NON-HEALINO ULCERS. FINGERNAILS AND NAIL BEDS MAY BE CONPLETELY DESTROYED. PENETRATION OF TIJE FLUORIDE ION TO DEL'P TISSUES MAY RESULT IN SLOW HEALING NECROSIS OF SOFT TISSUES AND DECALCIFICATION OF DONE. VAPORS AT A CONCENTRATION OF OF 120 PPY CAUSED SMARTING OF EXPOSED SKIN IN PEOPLE IN ONE MINUTE. SYSTEMIC ILUORIDE POISONING TIROUGH SKIN ABSORPTION MAY OCCUR. STUPOR, UNRESPONSIVENESS TO STIMULI _OTHER _THAN -RAIN,_.SEVERE NAUSEA, . YOMTTING, AND REDUCED PULSE RATE WLRE REPORTED IN ONE CASE.

CIRONIC EXPOSURE- REPEATED OR PROLONGED EXPOSURE MAY CAUSE IRRITATION OR DURNS. SLIGITT IRRITATION OCCURRED IN PEOPLE EXPOSED TO VAPOR CONCENTRATIONS AVERAGING 2.6 AND 4.7 PPM FOR PERIODS OF UP TO 50 DAYS. SLIGIT DESQUAMATION OF TIE SUPERFICIAL EPITIELIUM OF TIE FACE WAS OBSERVED IN ONE SUEJECT AFTER TEN DAYS OF EXPOSURE TO HYDROGEN FLUORIDE AT 3.4 PPM. 
EIRST AID- REMOVE CONTAMINATED CLOTUING AND SHOES IMMEDIATELY. WASH AFFECTED AREA WITI SOAP OR MILD DETEROTNT AND LARGE AMOUNTS OF WATER UNTIL NO EVIDENCE OF CHENICAL REMAINS (AT LEAST 15-20 MINUTES). IN CASE OF CHEMICAL BURNS, COVER AREA WITI STERILE, DRY DRESSING. BANDAGE SECURELY, DUT NOT TOO TIGHTLY. GET MEDICAL ATTENTION IMMEDIATELY.

EYE CONTACT :

IIYDROGEN FLUORIDE:

CORROSIVE.

ACUTE EXPOSURE- EXPOSURE TO IIYDROGEN FLUORIDE AVERAGING 4.7 PPM FOR 6 IIOURS, OR 30 PPM FOR SEVERAL MINUTES CAUSED MILD IRRITATION, WHILE 120 PPM RESULTED IN MARKED CONJUNCTIVAL IRRITATION WITIIN 1 MINUTE IN HUMANS. DIRECT CONTACT WITH THE LIQUID OR SOLUTIONS MAY CAUSE CORNEAL BURNS. IF NOT PROMPTLY REMOVED, PERMANENT VISUAL DITECTS OR BLINDNESS MAY RESULT. ONE WORKER EXPOSED TO A FINE SPRAY OF CONCENTRATED HYDROGEN FLUORIDE, HAD LOSS OF EPITHELIUM FROH THE CORNEA AND CONJUNCTIVA, AND MARKED EDEMA OF THE EYELIDS, CONJUNCTIVA, AND CORNEAS; PROMPT TREATMENT WAS ADHINISTERED. NORMAL VISION WAS REGAINED WITIIIN 19 DAYS.

CIIRONIC EXPOSURE- HUMANS EXPERIMENTALLY EXPOSED TO CONCENTRATIONS WHICII AVERAGED 2.6-4.7 PPM TOR UP TO 50 DAYS DEVELOPED MILD EYE IRRITATION. IN ANIMALS, REPEATED OR PROLONGED EXPOSURE TO LOW VAPOR CONCENTRATIONS CAUSED SLIGHT LACRIMATION.

FIRST AID- WASH EYES IMMEDIATELY WITH LARGE AMOUNTS OF WATER, OCCASIONALLY LIFTINO UPPER AND LOWER LIDS, UNTIL NO EVIDENCE OF CIIEMICAL REMAINS (AT LEAST 15-20 MINUTES). CONTINUE IRRIGATING WITH NORHAL SALINE UNTIL TIE PII HAS RETURNED TO NORMAL (30-60 MINUTES). COVER WITH STERILE BANDAGES. GET MEDICAL ATTENTION IMMEDIATELY.

INGESTION :

HYDROGEN ELUORIDE :

CORROSIVE.

ACUTE EXPOSURE- INGESTION HAY CAUSE BURNS OF TIE MOUTH, ESOPILGUS, STOMACH AND SMALL INTESTINE WITH GASTRITIS, GASTRIC IIEMORRHAGES, VOHITING, NAUSEA, ADDOMINAL FAIN, AND DIARRHEA. LARGE DOSES MAY CAUSE EXTENSIVE NECROSIS WITH PERFORATION OF THE STOMACII, SIOCK AND DEATII. SYSTEMIC POISONING MAY CAUSE IIYPOGLYCEMIA, IJYPERKALEMIA, HYPOMAGNESEMIA, AND SEVERE IIYPOCALCEMIA RESULTING IN TETANY, ESPECIALLY OF THE EXTREMITIES, AND PARESTHESIAS. HYPOTENSION, CIRCULATORY SIIOCK AND CARDIAC ARRIYTHMIAS INCLUDING SINUS TACHYCARDIA. OR VENTRICULAR FIDRILLATION, SOMETIMES PRECEDED BY TACIYYCARDIA, MAY OCCUR. CENTRAL NERVOUS SYSTEM SYMPTOMS MAY INCLUDE HEADACHE, EXXESSTVE SALIVATION, NYSTAGMUS AND DILATED PUPILS, LETHARGY, STUPOR, CONA, AND RARELY, TRANSIENT CONVULSIONS. DEATI IS USUALLY DUE TO RESPIRATORY PARALYSIS OR CARDIAC FAILURE. IN NON-FATAL CASES, JAUNDICE AND KIDNEY DAMAGE WITH ALBUHINURIA, IIEMATURIA, OLIGURIA OR ANURIA MAY OCCUR, BUT ARE GENERALLY REVERSTBLE. ASPIRATION HAY LEAD TO CHEMICAL PNEUMONITIS.

CHRONIC EXPOSURE- CHRONIC INGESTION OF SMALL AMOUNTS MAY CAUSE FLUOROSIS WITH OSTEOSCLEROTIC THICKENING WITH CALCIFICATION IN LIGAYENTOUS ATTACHMENTS OF SKELETON, WEIOHT LOSS,...BRITILEMES OF. DONES, REDUCED BONE MARROW SPACE WITH ANEMIA, WEAKNESS, GENERAL ILL HEALTH, STIFFNESS OF JOINTS, AND DISCOLORATION OF DEVELÓPING TEETIl. RARELY, CENTRAL NERVOUS SYSTEM INVOLVEMENT OCCURS.

FIRST AID- DO NOT USE GASTRIC LAVAGE OR EMESIS. DILUTE THE ACID IMMEDIATELY BY DRINKING LARGE QUANTITIES OF WATER OR MILK. IF VOMITINO PERSISTS, ADMINISTER FLUIDS REPEATEDLY. INGESTED ACID MUST BE DILUTED APPROXIMATELY 


\section{ANTIDOTE:}

100 FOLD TO RENDER IT IIARMLESS TO TISSUES. MAINTAIN AIRWAY AND TREAT SHOCK (DREISDACII, IIANDBOOK OF POISONING, 12TH ED.). GET MEDICAL ATTENTION IMMEDIATELY. IF VOMITING OCCURS, KEEP HEAD BELOW HIPS TO IIELP PREVENT ASPIRATION.

MSDS $\# 039275$

NO SPECIFIC ANTIDOTE. TREAT SYMPTOMATICALLY AND SUPPORTIVELY.

\section{REACTIVITY}

\section{REACTIVITY:}

REACTS EXOTHERMICALLY WITH WATER OR STEAM WITU THE RELEASE OF TOXIC AND CORROSIVE FUMES.

INCOMPATIBILITIES :

IIYDROGEN FLUORIDE:

ACETIC ANIYDRIDE: TEMPERATURE AND PRESSURE INCREASE IN A CLOSED CONTAINER. 2-AMINOETIIANOL: TEMPERATURE AND PRESSURE INCREASE IN A CLOSED CONTAINER. AMMONIUM HYDROXIDE: TEMPERATURE AND PRESSURE INCREASE IN A CLOSED CONTAINER. ARSENIC TRIOXIDE: INCANDESCENT REACTION.

BISMUTHIC ACID: VIOLENT REACTION EVOLVING OZONISED OXYGEN.

CALCIUM OXIDE: VERY VIOLENT REACTION WITI INCANDESCENCE.

CILOROSULFURIC ACID: TIMPERATURE AND PRESSURE INCREASE IN A CLOSED CONTAINER.

COATINGS: ATTACKED.

CONCRETE: ATTACKED.

CYANOGEN FLUORIDE: EXPLOSIVE POLYMERTZATION REACTION.

DIPIOSPHOROUS PENTOXIDE: VIOLENT REACTION,

ETIYLENEDIAMINE: TEMPERATURE AND PRESSURE INCREASE IN A CLOSED CONTAINER.

ETKYLENEIMINE: TEMPERATURE AND PRESSURE INCREASE IN A CLOSED CONTAINER.

FLUORINE: ENERGETIC REACTION WITH IGNITION.

GLASS : ATTACKED.

LEATIIER: ATTACKED.

METALS: MAY GENERATE FLAMMABLE IYYDROGEN GAS UPON CONTACT.

MERCURY OXIDE: EXOTKERMIC REACTION UNLESS ADEQUATE COOLING KEEPS REACTION TEMPERATURE BELOW O C.

METHANESULFCNIC ACID: ELECTROLYSIS OF A MIXTURE PRODUCED OXYGEN DIFLUORIDE WIIICII EXPLODED.

NITRIC ACID: IGNITION.

NITRIC ACID + GLYCEROL: TEMPERATURE AND PRESSURE INCREASE IN A CLOSED CONTAINER.

NITRIC ACID + LACTIC ACID: UNSTADLE MIXTURE.

NITRIC ACID, PROPYLENE GLYCOL, AND SILVER NITRATE: UNSTABLE MIXTURE.

OLEUM: TEMPERATURE AND PRESSURE INCREASE IN A CLOSED CONTAINER.

ORGANIC MATERIALS: ATTACKED.

N-PHENYLAZOPIPERIDINE: VIOLENT REACTION.

PHOSPHORUS(V) OXIDE: VIGOROUS REACTION BELOW $20 \mathrm{c}$.

PLASTICS : ATTACKED.

POTASSIUM PERMANGANATE: VIOLENT, EXOTHERMIC REACTION WITH CONCENTRATED ACID. POTASSIUM TETRAFLUORISILICATE: VIOLENT-EVOLUTION OF SILICON TETRAELUORIDE.

PROPIOLACTONE (BETA): TEMPERATURE AND PRESSURE INCREASE IN A CLOSED CONTAINER.

PROPLYLENE CXIDE: TEMPERATURE AND PRESSURE INCREASE IN A CLOSED CONTAINER. RUBBER (NATURAL): ATTACKED.

SILICA CONTAINING MATERIALS: CORROSIVE.

SODIUM: REACTS WITII EXPLOSIVE VIOLENCE WITII AQUEOUS ACID.

SODIUM HYDRCXIDE: TEMPERATURE AND PRESSURE INCREASE IN A CLOSED CONTAINER. 
SULFURIC ACID: TEMPERATURE AND PRESSURE INCREASE IN A CLOSED CONTAINER. TETRAFLUOROSILICIC ACID: VIOLENT REACTION.

VINYL ACETATE: TEMPERATURE AND PRESSURE INCREASE IN A CLOSED CONTAINER.

DECOMPOSITION:

MSDS* 039275

THERMAL DECOYPOSITION MAY RELEASE CORROSIVE IIYDROGEN FLUORIDE.

POLYHERIZATION :

IIAZARDOUS POLYMERIZATION IIAS NOT BEEN REPORTED TO OCCUR UNDER NORMAL TEMPERATURES AND PRESSURES.

STORAGE AND DISPOSAL

ODSERVE ALL FEDERAL, STATE AND LOCAL REgULATIONS WHEN STORING OR DISPOSING OF THIS SUBSTANCE. FOR ASSISTANCE, CONTACT THE DISTRICT DIRECTOR OF THE ENVIRONMENTAL PROTECTION AGENCY.

\section{**STORAGE**}

PROTECT AGAINST PHYSICAL DAMAGE, STORE IN WELL-VENTILATED AREA, SEPARATED FROM OTHER STORAGE (NFPA 49, IIAZARDOUS CHEMICALS DATA, 1975 ).

STORE AWAY FROM INCOMPATIBLE SUBSTANCES.

**DISPOSAL**

DISPOSAL MUST BE IN ACCORDANCE WITI STANDARDS APPLICADLE TO GENERATORS OF HAZARDOUS WASTIE, 40 CFR 262 . EPA HAZARDOUS WASTE NUMBER DOO2.

100 POUND CERC.LA SECTION 103 REPORTADLE QUANTITY.

\section{CONDITIONS TO AVOID}

MAY BURN DUT DOES NOT IGNITE READILY. MAY IGNITE COMDUSTIBLES (WOOD, PAPER, OIL, ETC.).

SOIL SPILL:

DIG IIOLDING ARIEA SUCII AS LAGOON, POND OR PIT FOR CONTAINMENT.

DIKE FLOW OF SIPILLED MATERIAL USING SOIL OR SANDBAGS OR FOAMED BARRIERS SUCH AS POLYURETHANE OR CONCRETE.

USE CEMENT POWDER OR FLY ASH TO ABSORB LIQUID MASS.

NEUTRALIZE SPIJL WITH SLAKED LIME, SODIUM BICARDONATE OR CRUSHED LIMESTONE.

AIR SPILL:

APPLY WATER SPRAY TO KNOCK DOWN AND REDUCE VAPORS. KNOCK-DOWN WATER IS CORROSIVE AND FOXIC AND SIIOULD BE DIKED FOR CONTAINMENT. 
WATER SPILL:

NEUTRALIZE WITH AORICULTURAL LIHE, SLAKED LIME, CRUSHED LIMESTONE, OR SODIUH BICARBONATE.

NIUTRALIZE WITH CAUSTIC SODA.

ADD SUITABLE AGENT TO NEUTRALIZE SPILLED MATERIAL TO PH-7.

USE MECILANICAL DREDGES OR LIFTS TO EXTRACT IMMOBILIZED MASSES OF POLLUTION AND PRECI ITATES.

OCCUPATIONAL SPILL:

DO NOT TOUCH SPILLED MATERIAL. STOP LEAK IF YOU CAN DO IT WITHOUT RISK. USE WATER SPRAY TO REDUCE VAPORS. FOR SMALL SPILLS, TAKE UP WITH SAND OR OTIIER ADSORDENT MATERIAL AND PLACE TNTO CONTAINERS FOR LATER DISPOSAL. FOR LARGER SPILLS, DIKE SPILL FOR LATER DISPOSAL. KEEP UNNECESSARY PEOPLE AWAY. ISOLATE HAZARD AREA AND DENY ENTRY.

\section{PROTECTIVE EQUIPMENT}

VENTILATION :

PROCESS ENCLOSURE RECOMMENDED TO MEET PUBLISHED EXPOSURE LIMITS.

RESPIRATOR:

THE FOLLOWING RESPIRATORS AND MAXIMUM USE CONCENTRATIONS ARE RECOMMENDATIONS BY THE U.S. DEPARTMENT OF HEALTH AND IIUMAN SERVICES, NIOSH POCKET GUIDE TO CHEMICAL IIAZARDS; NIOSII CRITERIA DOCUMENTS OR BY THE U.S. DEPARTMENT OF LABOR, 29 CFR 1910 SUBPART $Z$.

THE SPECIFIC RESPIRATOR SELECTED MUST BE BASED ON CONTAMINATION LEVELS FOUND IN TIE WORK PLACE, WUST NOT EXCEED THE WORKINO LIMITS OF TIE RESPIRATOR AND BE JOINTLY APPROVED BY THE NATIONAL INSTITUTE FOR OCCUPATIONAL SAFETY AND HEALTI AND THE MINE SAFETY AND HEALTII ADMINISTRATION (NIOSH-KSHA).

HYDROGEN FLUORIDE:

30 PPM- ANY SUPPLIED-AIR RESPIRATOR ANY SELF-CONTAINED BREATIING APPARATUS.

ANY POWERED AIR-PURIFYINO RESPIRATOR WITH CARTRIDGE(S) PROVIDING PROTECTION AGATNST HYDROGEN FLUORIDE.

ANY CHEMICAL CARTRIDGE RESPIRATOR WITII CARTRIDGE(S) PROVIDING PROTECTION AGAINST HYDROGEN FLUORIDE.

ANY AIR-PURIFYING FULL FACEPICCE RESPIRATOR (GAS MASK) WITH A CHIN-STYLE OR FRONT- OR DACK-MOUNTED CANISTER PROVIDING PROTECTION AGAINST HYDROGEN FLUORIDE.

ESCAPE- ANY AIR-PURTFYING FULL FACEPIECE RESPIRATOR (GAS MASK) WITh A CHIN - STYLE OR FRONT- OR BACK-MOUNTED CANISTER PROVIDING PROTECTION AGAINST HYDROGEN FLUORIDE.

ANY APPROPRIATE ESCAPE-TYPE SELF-CONTAINED BREATHING APPARATUS.

FOR FIREFIGHTING AND OTHER IMMEDIATELY DANGEROUS TO LIFE OR HEALTI CONDITIONS:

SELF-CONTAINED BREATHING APPARATUS WITH FULL FACEPIECE OPERATED IN PRESSURE-DEYAND OR OTIIER POSITIVE PRESSURE MODE.

SUPPLIED-AIR RESPIRATOR WITH FULL FACEPIECE AND OPERATED IN PRESSURE-DEMAND OR OTIER POSITIVE PRESSURE MODE IN COMBINATION WITII AN AUXILIARY 

SELF-CONTAINED BREATIING APPARATUS OPERATED IN PRESSURE-DEMAND OR OTHER POSITIVE PRESSURE MODE.

CLOTHING:

EMPLOYEE MUST WEAR APPROPRIATE PROTECTIVE (IMPERVIOUS) CLOTHING AND EQUIPHENT TO PREVENT ANY POSSIBILITY OF SKIN CONTACT WITH THIS SUBSTANCE,

GLOVES :

EMPLOYEE MUST WEAR APPROPRIATE PROTECTIVE GLOVES TO PREVENT CONTACT WITII TILIS SUBSTANCE.

EYE PROTECTION:

EMPLOYEE MUST WEAR SPLASII-PROOF OR DUST-RESISTANT SAFETY GOGGLES AND A FACESHIELD TO PREVENT CONTACT WITH THIS SUBSTANCE.

EMERGENCY WASII TACILITIES:

WHERE THERE IS ANY POSSIBILITY THAT AN EMPLOYEE'S EYES AND/OR SKIN MAY BE EXPOSED TO THIS SUBSTANCE, THE EMPLOYER SHOULD PROVIDE AN EYE WASH FOUNTAIN AND QUICK DRENCI SHOWER WITHIN TIIE IMMEDIATE WORK AREA FOR EMERGENCY USE.

AUTHORIZED DY- SPECTRUM CIIEMICAL MFG. CORP, 
SPECTRUM CIIRMICAL MFG. CORP.

14422 S. San Pedro Street

Oardena, CA 90248-9985

Phone : (213) \$16-8000
EMERGENCY CONTACT:

CIIEHTREC (800) 424-9300

SPECTRUM TECIINICAL SERVICE (213) 516-8000

MSDS * 039275

The statements contained herein are offored for informational purposes only and are intended to be followed only by perwone having related technical skills and at their own discretion and risk. Since conditions and manner of use are outside our control, we make no warranties, express or implied, and no liability in connection with any use of this information. 


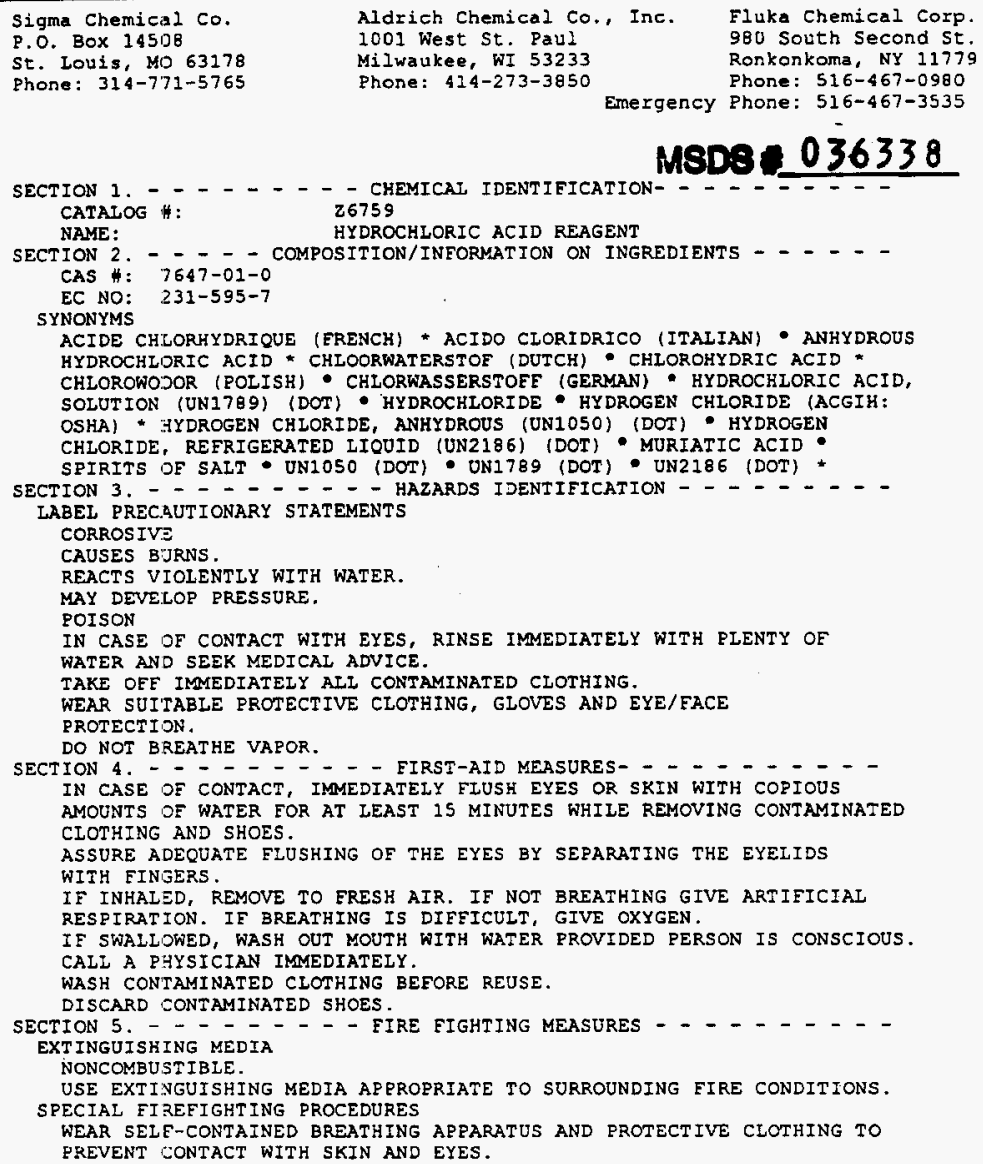




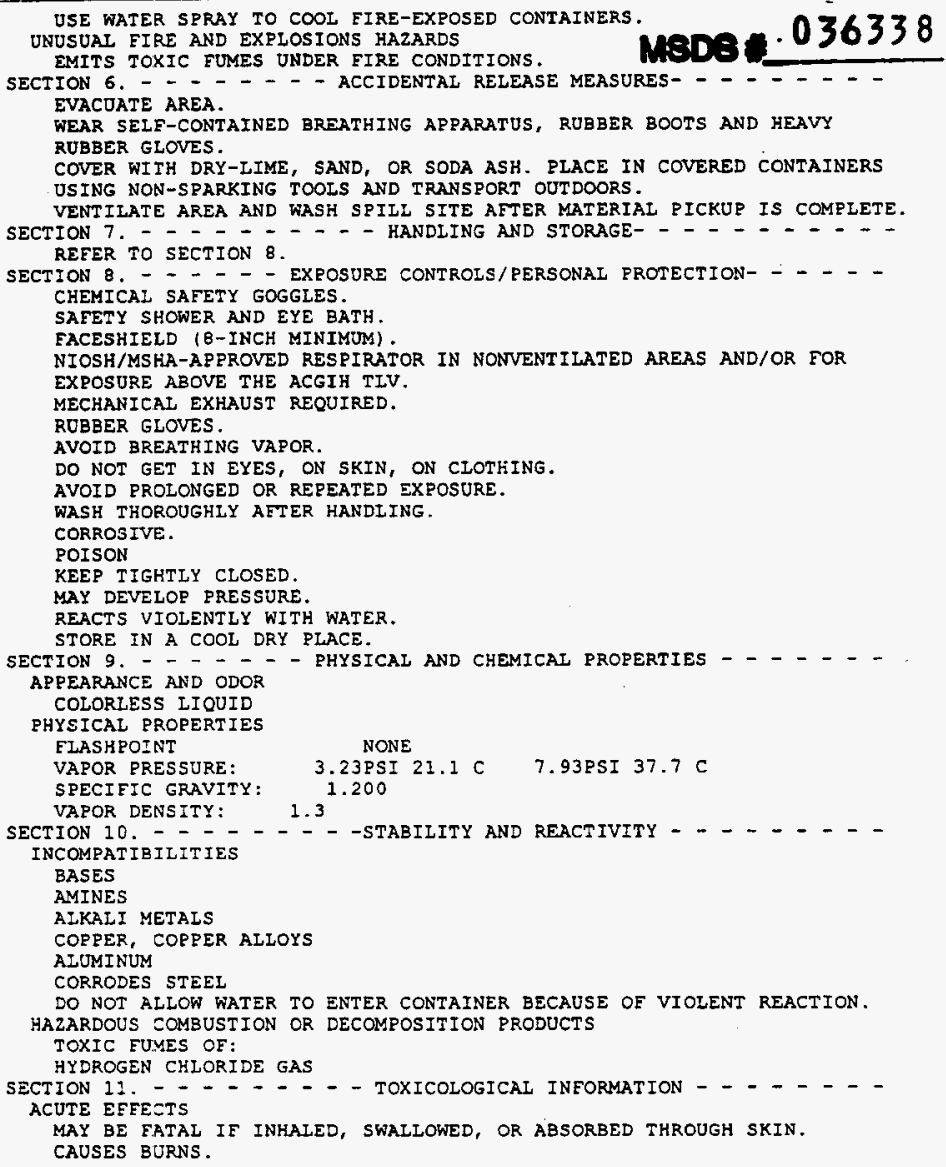

Page 2 
PRODUCT H: 26759 NAME: HYDROCHLORIC ACID REAGENT

MATERIAL SAFETY DATA SHEET, Valid 2/96 - 4/96

Printed Thursday, February 01, 1996 10:50AM

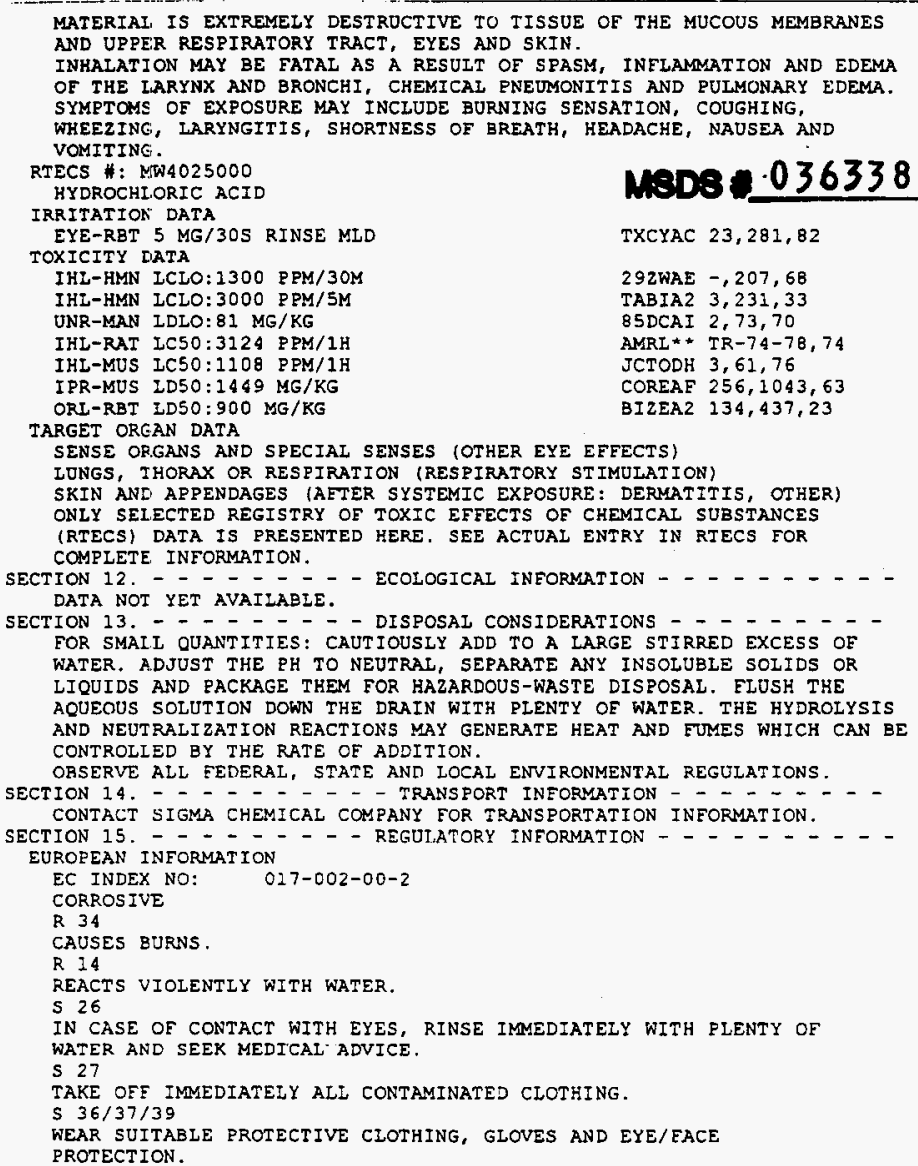

TARGET ORGAN DATA

SENSE ORGANS AND SPECIAL SENSES (OTHER EYE EFEECTS)

LUNGS, THORAX OR RESPIRATION (RESPIRATORY STIMULATION)

SKIN AND APPENDAGES (AFTER SYSTEMIC EXPOSURE: DERMATITIS, OTHER)

ONLY SELECTED REGISTRY OF TOXIC EFFECTS OF CHEMICAL SUBSTANCES

(RTECS) DATA IS PRESENTED HERE. SEE ACTUAL ENTRY IN RIECS FOR COMPLETE INFORMATION.

SECTION 12. - - - - - - ECOLOGICAL INEORMATION - - - - - DATA NOT YET AVAILABIE.

SECTION 13. - - - - - - DISPOSAI CONSIDERATIONS - - - - - - FOR SMALL QUANTITIES: CAUTIOUSLY ADD TO A LARGE STIRRED EXCESS OF WATER, ADJUST THE PH TO NEUTRAL, SEPARATE ANY INSOLUBLE SOLIDS OR LIQUIDS AND EACKAGE THEM FOR HAZARDOUS-WASTE DISPOSAL. ELUSH TKE AOUEOUS SOLUTION DOWN THE DRAIN WITH PLENTY OE WATER. THE HYDROIYSIS AND NEUTRALIZATION REACTIONS MAY GENERATE HEAT AND FUMES WHICH CAN BE CONTROLIED BY THE RATE OE ADDITION. ORSERVE ALL EEDERAL, STATE AND LOCAL ENVIRONMENTAL REGUIATIONS.

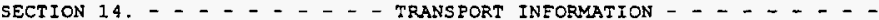
CONTACT SIGMA CHEMICAL COMPANY FOR TRANSPORTATION INEORMATION.

SECTION 15 - - - - - - - REGULATORY INFORMATION - - - - - - - -

EUROPEAN INFORMATION

EC INDEX NO: 017-002-00-2

CORROSIVE

R 34

CAUSES BURNS.

R. 14

REACTS VIOLENTIY WITH WATER.

S 26

IN CASE OF CONTACT WITH EYES, RINSE IMMEDIATEIY WITH FLENTY OF WATER AND SEEK MEDICAI ADVICE.

S 27

TAKE OFE IMMEDIATELY ALI CONTAMINATED CLOTHING.

S 36/37/39

WEAR SUITABLE PROTECTIVE CLOTHING, GLOVES AND EYE/EACE

PROTECTION.

Fage 3 
PRODUCT * 26759 NAME: HYDROCHLORIC ACID REAGENT

MATERIAL SAFETY DATA SHEET, Valid $2 / 96-4 / 96$

Printed Thursday, February 01, 1996 20:50AM

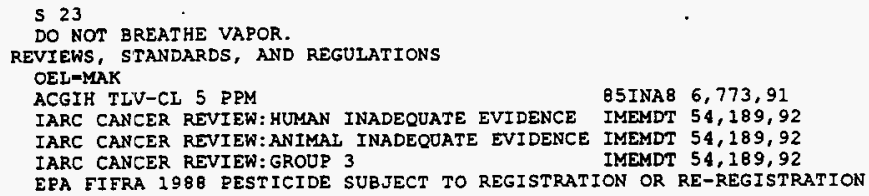


PRODUCT \#: 26759 NAME: HYDROCHLORIC ACID REAGENT MATERIAL SAFETY DATA SHEET, Valid $2 / 96$ - 4/96 Printed Thussday, February 01, 1996 10:50AM

SECTION 16. - - - - - - - - OTHER INFORMATION- - - - - - - - -

THE ABOVE; INFORMATION IS BELIEVED TO BE CORRECT BUT DOES NOT PURPORT TO BE ALL INCLUSIVE AND SHAIL BE USED ONIY AS A GUIDE. SIGMA, AIDRICH, FLUKA SHALL NOT BE HELD LIABLE FOR ANY DAMAGE RESULTING FROM HANDLING OR FROM CONTACT WITH THE ABOVE PRODUCT. SEE REVERSE SIDE OF INVOICE OR PACKING SIIP FOR ADDITIONAI TERMS AND CONDITIONS OF SALE.

COPYRIGHT: 1995 SIGMA CHEMICAL CO., ALDRICH CHEMICAL CO., INC., FLUKA CHEMIE AG

IICENSE GRANTED TO MAKE ONLIMITED PAPER CORIES FOR INTERNAL USE ONIY

\section{MBDS 036338}




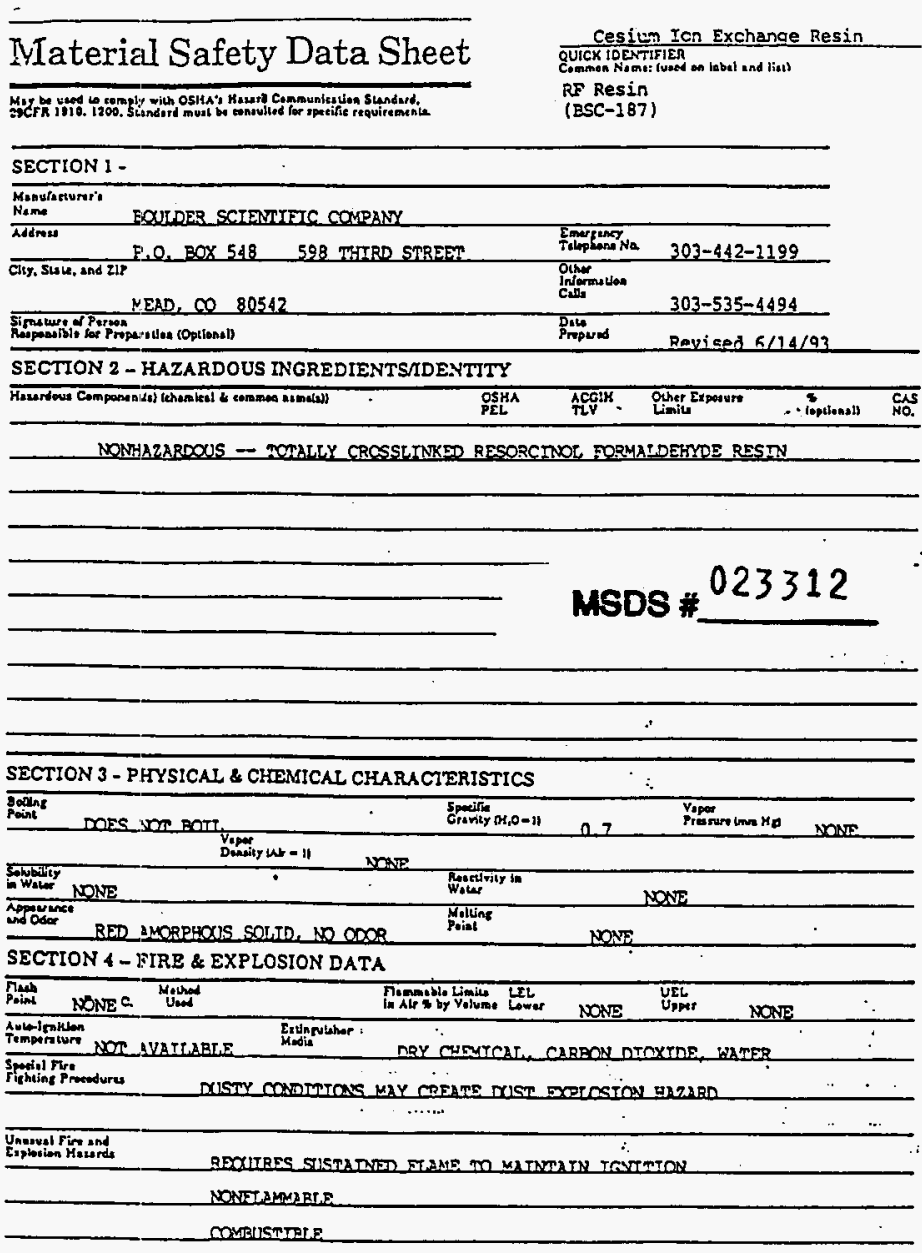




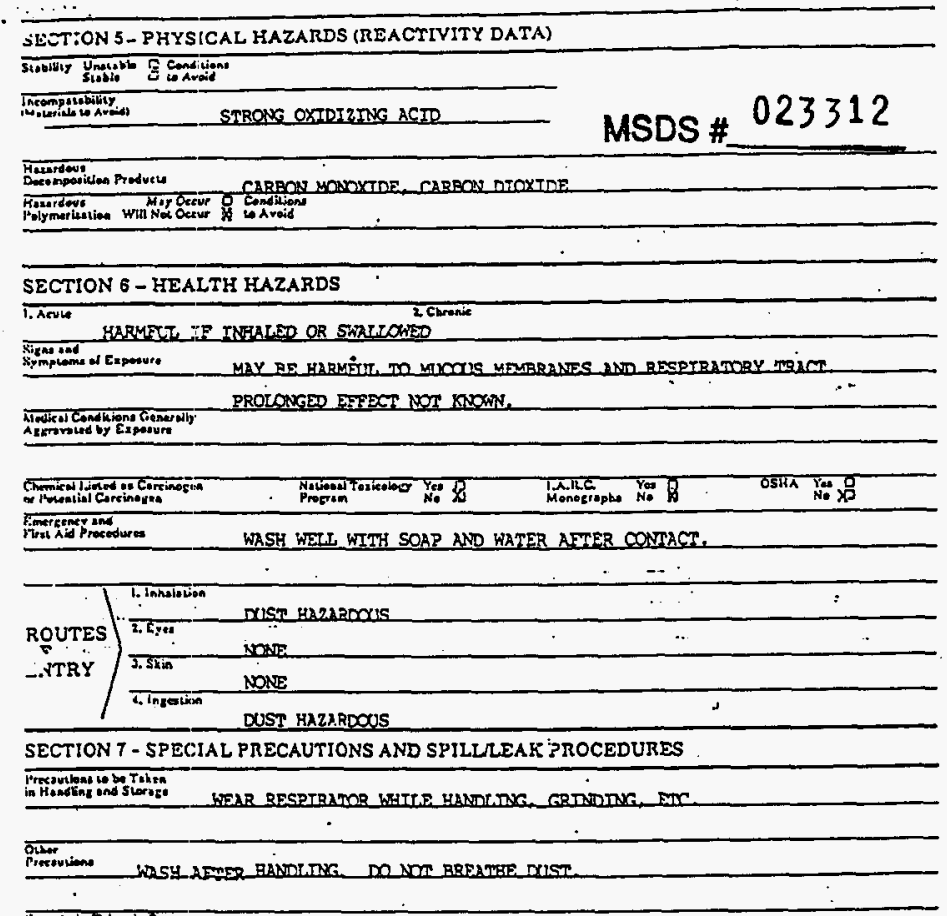

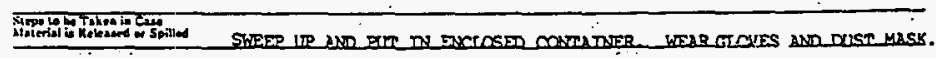

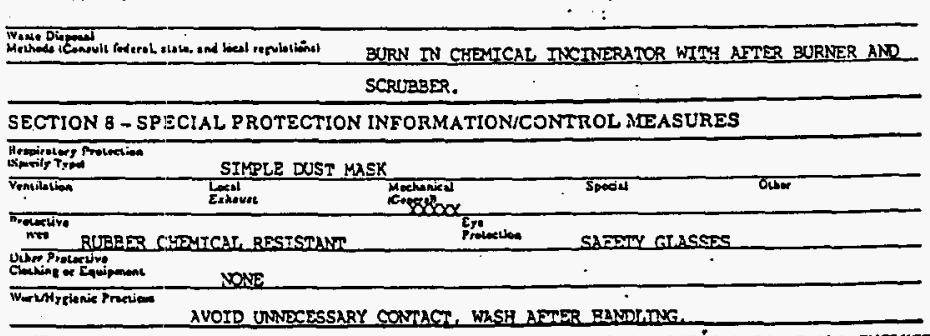

THE ABOVE INFORMATION IS BELIEVED TO BE CORRECT BUT DOES NOT FUR'FORT TO BE ALC INCIUSIVE AND SHULL BE USDD ONLY AS A GUTDE. BOULDER SCIDMITFIC CONPANY SHAIL NOL BE YITD IFABLE FOR ANY DNUAR OR INUTRY RESULITING FAON HANOLING OR FROH CONAACT WITH THE ABOVE PROOUCT. 
MAY 13 'S6 1.1:43AM WOP MT LALRE NJ

P. 216

\section{Ue Material Safety Data Sheet}

1. EXPEAIMENTTAL PRODUCT AND COMPANY IDENTIFICATION

Page it of 5

PRODUCT: UOPm IONSIVm Ion Exchanger TYpe IE-911

UOP

25 E Aponquin Foud

Des Platnot, it axp17.5017

Tolophone: 47-101-3190

FAX: BA7-301-2043

Tolox 211462

\section{COMPOSITION}

MATEOIAL

sitleion diexdos

Titanium dioxdce

Sodium oxide

Trade Secret material

Trade Secrer metal oxide

Auminum oxide

(non-fibrous)

\section{Copper oxide}

Calcium oxide

Chromium oxide

Magnesium axde
CASNo.

$7631-86-9$

$13463-67.7$

$1313-89-3$

Trede Secret

Trade Secrer

1344-28-1

$1317-38-0$

$1305-78-8$

$1300-38-9$

$1309-48-4$

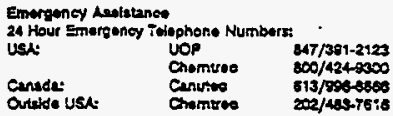

$\therefore$

MSDS\#053329

i 995-96 ACGIH TLVTWA

$-w / \%$

(1995 OSHA PEL.TWAL

$15 \cdot 45$

$10 \mathrm{mg} / \mathrm{m}^{2}$ as Si ictal dust

(15 $\mathrm{mg} / \mathrm{m}^{3}$ as Si iotal dust)

(5 mg/mis as Si respirable dust)

$20 \cdot 40$

$10 \mathrm{mg} / \mathrm{m}^{3}$

(15 $\mathrm{mg} / \mathrm{m}^{3}$ as tespirable dust)

$5-20$

None sstablished

$15 \cdot 25$

None establlshed

0.25

$5 \mathrm{mg} / \mathrm{m}^{3}$, STEL $10 \mathrm{mg} / \mathrm{m}^{3}$

$\left(5 \mathrm{mg} / \mathrm{m}^{\mathrm{j}}\right.$, STEL $\left.10 \mathrm{mg} / \mathrm{m}^{2}\right)$

$0-10$

$10 \mathrm{mg} / \mathrm{m}^{3}$ total dust

$5 \mathrm{mg} / \mathrm{m}^{2}$ respirable dust

(15 $\mathrm{mg} / \mathrm{m}^{3}$ total dust)

(5 $\mathrm{mg} / \mathrm{m}^{3}$ respirable dust)

None establlshed

$2.0 \mathrm{mg} / \mathrm{m}^{3}$

(5.0 $\mathrm{mg} / \mathrm{m}^{3}$ )

0.2

None established

0.2

$10 \mathrm{mg} / \mathrm{m}^{3}$

0.2

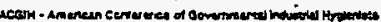

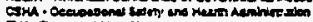

RY-Treanole ung vew

TWA. Trme Women herage.

\section{HAZARDS IDENTIFICATION}

\section{EMERGENCY OVERMEW:}

This white erysalline powder may cause stin and eye iritation. Inhalation of dust mey cause respiratory iritation. Product is considered to heve a low oral toricily. 
Primary Routes of Exposure:

Contact with skin and eyes. Expcsure may also cceur via inhalation or ingestlon if product dust is generated during handling. Product ingestion is unlikoly but may oceur if proper salety/trygiente procedures are not followed.

Skin Contact:

The solid or dust may cause irritation with repeated or prelonged exposure.

Eyo Contact:

Solld or dust may cause ifritation or reddening due to mechanical ection. Mid to moderane irritation of eye membrane may also oceur possibly resulting in swelling.

Inhadation:

May cause iritation of the nose and throat accompenied by cough and chest diseomior. Prolonged inhalation may cause lung damage.

Ingestlon:

This product is considered to have a low order of toxictiy.

Carcinogenlety Classification:

IAPC: Titanium dioxide and Silicon diexide - Not dassifable as human carcinogens (Group 3). None of the other components are classified.

NTP: Nene of the product components are classified.

Osida: Nene of the product components are classitled.

\section{FIRST AID MEASURES}

Skin: Wash affected area with soep and water. If iritatlon oceurs, obtain medical attention.

Eyes: $\quad$ Fush with water for at least 15 minutes. it irmation persists, obtain medleal attention.

Inhalation: Aemove affecied person to fresh atr. If breathing is difficult, oxygen may be needed; obtaln medical aitention.

Ingestion: Do not induce vomiting Victim should órink large quantities of mik, gelatin soludion or water. Cttaln medieal attertion.

\section{FIRE FIGHTING MEASURES}

Fiash Point: Not applicable

Method: Not applicable

Extingulething Media; Materal does net bum. Use media appropriate for surrounding fre farbon dioxide, dry chemical or foam).

Fire and Explosion Hazard: Used materlal may contain products of a hazardeus nature. The user of this product must identify the hazaros of the cotained material and inform the fire fighters of these hazands.

\section{ACCIDENTAL AELEASE MEASURES}

I solate the affectecl arva; restrict entry to the affected area io personnel wearing proper personal protectve equipment. Spectal anention should be glven to respiratory and zye protection, because recovery of msterial can be expected to cenerate duse Vacuum or shovel up spilled material. placing it into appropriate recovery dnums or containers.

\section{HANDLINGi AND STORAGE}

Store in tghtly closed, property laveled containers. Do not take internally. Avold repeated or proionged contace whe skin. Avoid contact with oyes and intralaton of dust. 
$\because \because \therefore$

MAY 13.96 11:44AM UOP MT LAFE N

P.4.5

IONSIV IE-911

Page 3 of 5

January 1906

\title{
8. EXPOSURE CONTROLS AND PERSONAL PROTECTION
}

Respiratory. Where natural ventiation is inedequate. use mechanical vantiation, other angineering controls or a toxic dust resplrator (m USA NIOSH/MSHA-approved) to prevent inhalation of dust

Skin: Chemical-resistant gloves and work uniform as necessery to prevent repeated or prolonged skin coritact.

Eye: Safty glasses or goggies as necessary to prevent eye contact.

9. PHYSICAL AND CHEMICAL PROPEATIES

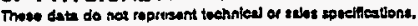

Boiling Point: Bulk Density: Vapor Pressure: Vapor Density: Pour Point: Freazing Point: Specilite Gravity
Not applicabie Not avalable
Not applleable
Not applicabie
Net applicable
Not appllcable
Not spolicable

Solubiry in Water: * Volatilo: Appoarance: Odor: $\mathrm{pH}$ in 10\% aqueous slurty: Physical State:

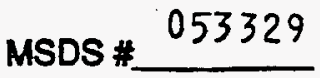

insoluble,

Not applicabla

White Cystalline Powder

Odortes:

approximately 11

Solid

\section{STABILITY' AND REACTIVITY}

\author{
Stabatry: \\ Stable. \\ Conditions to Avoid: \\ None known \\ Hazardous Decomposition Procucts: None. \\ Hazardous Polymentzation: Wil not cecur. \\ Incompatible Materials: Avoid centeet with acid and easily oxldized materials.
}

\section{TOXICOLOGICAL INFORMATION}

No data avallable tor this product, the following sata is for a simiar product:

Orat LOSO

Eye Irritation

Skin Irritation

Skin Sensitization

Cyotoxity
$>5 \mathrm{~g} / \mathrm{kg}$ (rat)

The produet is no more than mocerately irritating to the eyes of rabbits. No comeal damoge was seen. irtis was seen in 2/6 animals after 1 hour, but none was seen after 48 hours. Al 8 rabbits showed irtitation of the conjunetha atter 1 hour, but after 72 hours only 1 still showed the irrtition.

The product is no more than sllghtly irikating to the skin of rabbits: only barely perceptible erythema wes noted at the i-hr score time in $2 / 6$ rabolks, score of 1 for 2/8 rabbits (maximum possible seore is a).

The product was found not to produce skin sensitization in guinea pigs.

The product is classitied in the nondetectable category acoording the IERL. cyrotexjeity schame (Sandhu, 1979). The product was considered to be noncytotoxje to rabblt alveolar macrophage cells at concentrattons less than or equal to $1000 \mu \mathrm{g} / \mathrm{m}$.

\section{ECOLOGIC INFORMATION}

No drea cerrenty available. 


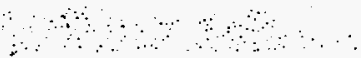

MAY 13.95 11: 4APM UOP MT LAREL NJ

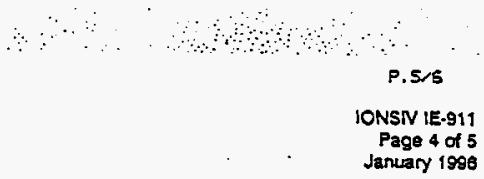

13. DISPOSAL CONSIDERATIONS

Dispoes of product in accordance whth at applieable covernment regulations. The unused product and its componemts are not listed by generic name or inadematk name in the U.S. EPA's Resource Conservation and Recovery Act (RCFA) Hazardous Waste Management Fegutations and do not possess any of the four identitying characteristles of hizardous waste.

\section{TRANSPORTATION INFORMATION}

DOT Hazard Classification: Nor Regutared

10 Number: Not Applicable

IMO Hazard Clastificution: Not Regutated

10 Number: Not Applicable

\section{REGULATIORY INFORMATION}

U.S. TOXCSUBSI'ANCES CONTROLACT TSCA): All the ingredients of this product are registered in accordance with TSCA

U.S. SUPEARIND AMENDMENTS AND REALTHCRIZATON ACT (SARA) TITLE II, SECTON 313: The following component(3) in this product is sublect to the reporting requiremente of section 313 of the Emergency Planning and Community Right-7'o-Know Act, 40 CFR 372: -nong-

EUROPEAN INYEATORY OFEXISTINC COMMERCIALCHEMICALSUBSTANCES (EINECS): The components of this preparation are included on the EINECS.

\begin{tabular}{|c|c|}
\hline 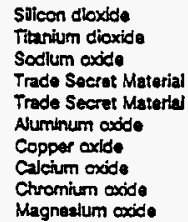 & $\begin{array}{l}2315454 \\
2366755 \\
2152089 \\
\text { listed } \\
\text { listed } \\
2156916 \\
2152691 \\
2151389 \\
2131609 \\
2151719\end{array}$ \\
\hline
\end{tabular}




\section{OTHER INFORMATION}

For addlional information concerning this product comect the following:

For health, solety a environmental informatlon, plessie contact:

Produet Stewardship Manager Heatth, Safety and Environmental Department UOP

25 E. Algonquin Rid.

Des Pleines, IL ※017-5017

Telephone: (847) $391-3180$

Fox (B47) $391-2953$
For technical of product pitrtastror Information, please contact:

\section{Account Manager}

UOP

307 Fellowshtp Rcad

Sulte 207

Mt Laurel, New Jersey 00054

Telephone: (609) 727.9400

- Fax (EOO) 727-9545

\section{PAODUCT EMERGENCIES}

If you have a product-rolated amergency, resulting in an incident such as a spil or release of product, human exposure, etc. and need assistance from UOP, please call us at the following number:

\section{HOU EMERGENCY Telephone Number:. (847) 391-2123}

The data and recummendartons presented in this data sheet conceming the use of our product and the materials contained therein are belleved to be aceurate and are besed on information which is considered rellable as of the date hereot. However, the customer should cotermine the sulablity of such materials for his purpese before adopting them on a commerctal scale. Since the use of our products by others is beyond our control, no guarantee, express or implied, is made and no responsblity assumed for the use of this material or the results to be obtained therefrom. information on this form is turnished for the ourpose of compliance with Government Health and Safety Regulations and shall not be used for any ether purposea. Moreover, the recommendations contained in this deat stheet are not to be construed as a llcense to operate under, or a recommendation to infringe, any existing patents, nor should they be contused with state. municipal or insurance requlrements, or with national safery cocles.

UOP

Dato: January 1998

Revision: 1

Supersedes: Fatinuary 1995 


\section{DISTRIBUTION SHEET}

\begin{tabular}{|c|c|c|c|c|c|}
\hline \multirow{2}{*}{$\begin{array}{l}\text { To } \\
\text { Distribution }\end{array}$} & \multirow{2}{*}{\multicolumn{3}{|c|}{$\begin{array}{l}\text { From } \\
\text { ETTP/PE }\end{array}$}} & \multicolumn{2}{|l|}{ Page 1 of 1} \\
\hline & & & & \multicolumn{2}{|c|}{ Date $05 / 31 / 96$} \\
\hline \multicolumn{4}{|l|}{ Project Title/Work Order } & \multicolumn{2}{|c|}{ EDT No. 611414} \\
\hline \multicolumn{4}{|c|}{$\begin{array}{l}\text { Test Procedures and Instructions for Hanford Tank Waste } \\
\text { Supernatant Cesium Removal }\end{array}$} & \multicolumn{2}{|l|}{ ECN No. } \\
\hline Name & MSIN & $\begin{array}{c}\text { Text } \\
\text { With All } \\
\text { Attach. }\end{array}$ & Text Only & $\begin{array}{l}\text { Attach./ } \\
\text { Appendix } \\
\text { Only }\end{array}$ & $\begin{array}{l}\text { EDT/ECN } \\
\text { Only }\end{array}$ \\
\hline
\end{tabular}

Akita, R.

Appe ], J. N.

Beck, M.A.

Benar, C. J.

Berger, J.D.

Brown, G.N.

Brown, L. C.

Duncan, J. B. (4)

Eberlein, S. J.

Edmondson, D. W.

Hall, M.J.

Hendrickson, D. W. (8)

Herting, D. L.

Hunter, J.A.

Hyatt, J. E.

Kurath, D.E.

Jewett, J.R.

Jaten, K.H.

Klem, M.J.

Lamson, S. B.

McDonald, G. T.

Narquis, C. T.

Smith, J. R.

Stewart, T.

TCRC (2)

Voogd, J. A.

Central Files (orig + 2)

PPE-
T6-20

G3-21

T6-09

R2-12

H6-34

P7-25

L5-62

L5-55

R2-12

T6-09

T6-12

L5-31

T6-09

L5-31

S3-31

P7-20

T6-09

T6-04

H5-27

T6-28

L5-31

T6-16

T6-09

K9-91

R2-12

H5-03

A3-88

A3 $=94$ $x$

$x$

$X$

$X$

$X$

$X$

$x$

$x$

$x$

$x$

$X$

$x$

$x$

$x$

$X$

$X$

$X$

$X$

$X$

$x$

$x$

$x$

$X$

$x$

$x$

$x$

